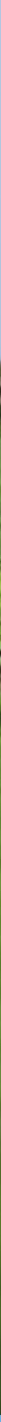

Milieurisico bestrijdingsmiddelen en veterinaire stoffen in mest via effecten op de voedselketen voor weidevogels 



\title{
Milieurisico bestrijdingsmiddelen en veterinaire stoffen in mest via effecten op de voedselketen voor weidevogels
}

John Deneer ${ }^{1}$, Dick Belgers ${ }^{1}$, Menno Thomas ${ }^{2}$, Ivo Roessink ${ }^{1}$

\author{
${ }^{1}$ Wageningen Environmental Research \\ ${ }^{2}$ Wageningen Universiteit - leerstoelgroep Diervoeding
}

Dit onderzoek is uitgevoerd door Wageningen Environmental Research en gesubsidieerd door het ministerie van Landbouw, Natuur en Voedselkwaliteit (projectnummer BO-43-011.01-022).

Wageningen Environmental Research

Wageningen, oktober 2020

Gereviewd door:

Dr. Louise Wipfler, onderzoeker (WENR)

Akkoord voor publicatie:

Maikel de Potter, teamleider van ERA

Rapport 3037

ISSN 1566-7197

ISBN 978-94-6395-575-1 
Deneer, J., D. Belgers, M. Thomas, I. Roessink, 2020. Milieurisico bestrijdingsmiddelen en veterinaire stoffen in mest via effecten op de voedselketen voor weidevogels. Wageningen, Wageningen Environmental Research, Rapport 3037. 62 blz.; 4 fig.; 5 tab.; 35 ref.

In 2019 verscheen een rapport van Buijs en Samwel-Mantingh waarin een mogelijke relatie gelegd werd tussen de aanwezigheid van bestrijdingsmiddelen en diergeneesmiddelen in mest van landbouwhuisdieren en de afname van weidevogels t.g.v. een afname in evertebraten (o.a. wormen en insecten) als voedselbron voor deze vogels. In deze verdiepende analyse van de gerapporteerde concentraties wordt onderzocht hoe betrouwbaar de gemeten concentraties zijn, of er een mogelijk risico voor bodemevertebraten van individuele stoffen en mengsels is en wat mogelijke routes van deze stoffen naar mest zijn.

In 2019, a report was issued by Buijs en Samwel-Mantingh which claimed a possible relation between the occurrence of pesticides and veterinary drugs in manure and the decline of farmland birds, which feed on (soil) invertebrates allegedly impacted by these substances. The current research project provides an in-depth analysis of the reliability of the measured concentrations, an analysis of the potential risk to (soil) invertebrates of single compounds and mixtures and an assessment of potential pathways of these substances into the manure.

Trefwoorden: bestrijdingsmiddelen, biociden, veterinaire middelen, mest, bodemevertebraten

Dit rapport is gratis te downloaden van https://doi.org/10.18174/532429 of op www.wur.nl/environmental-research (ga naar 'Wageningen Environmental Research' in de grijze balk onderaan). Wageningen Environmental Research verstrekt geen gedrukte exemplaren van rapporten.

2020 Wageningen Environmental Research (instituut binnen de rechtspersoon Stichting Wageningen Research), Postbus 47, 6700 AA Wageningen, T 03174807 00, www.wur.nl/environmental-research. Wageningen Environmental Research is onderdeel van Wageningen University \& Research.

- Overname, verveelvoudiging of openbaarmaking van deze uitgave is toegestaan mits met duidelijke bronvermelding.

- Overname, verveelvoudiging of openbaarmaking is niet toegestaan voor commerciële doeleinden en/of geldelijk gewin.

- Overname, verveelvoudiging of openbaarmaking is niet toegestaan voor die gedeelten van deze uitgave waarvan duidelijk is dat de auteursrechten liggen bij derden en/of zijn voorbehouden.

Wageningen Environmental Research aanvaardt geen aansprakelijkheid voor eventuele schade voortvloeiend uit het gebruik van de resultaten van dit onderzoek of de toepassing van de adviezen.

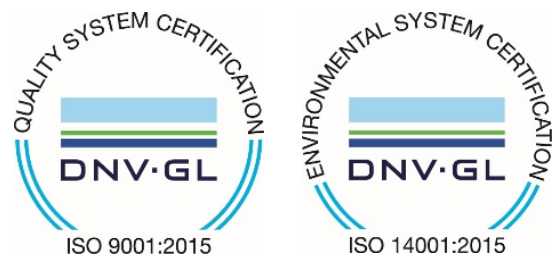

Wageningen Environmental Research werkt sinds 2003 met een ISO 9001 gecertificeerd kwaliteitsmanagementsysteem. In 2006 heeft Wageningen Environmental Research een milieuzorgsysteem geïmplementeerd, gecertificeerd volgens de norm ISO 14001.

Wageningen Environmental Research geeft via ISO 26000 invulling aan haar maatschappelijke verantwoordelijkheid.

Wageningen Environmental Research Rapport 3037 | ISSN 1566-7197

Foto omslag: Shutterstock 


\section{Inhoud}

$\begin{array}{ll}\text { Verantwoording } & 5\end{array}$

$\begin{array}{ll}\text { Samenvatting } & 7\end{array}$

$\begin{array}{llr}1 & \text { Inleiding } & 9\end{array}$

$2 \quad$ Projectdoelstelling en methodologie

10

3 Hoe betrouwbaar zijn de in het rapport van Buijs en SamwelMantingh (2019) gemeten gehalten van middelen? $\quad 12$

3.1 Gebruikte laboratoria $\quad 12$

3.1 .1 Eurofins $\quad 12$

3.1.2 RIKILT 13

$\begin{array}{lll}3.2 & \text { Conclusie } & 13\end{array}$

In welke mate vormen de in het rapport gerapporteerde concentraties van de afzonderlijke stoffen individueel en/of in combinatie een risico voor evertebraten in mest en bodem?

4.1 Verzamelen toxiciteitsgegevens $\quad 14$

4.1.1 Bestrijdingsmiddelen (inclusief biociden) 14

4.1.2 Veterinaire middelen $\quad 16$

4.2 Afleiding gebruikte toetsconcentraties 16

4.2.1 Beoordeling werking van individuele stoffen 16

4.2.2 Beoordeling combinatiewerking van mengsels van stoffen 17

4.3 Berekening blootstelling uit de gerapporteerde meetgegevens 18

4.4 Resultaten toetsing individuele stoffen aan standaard bodemorganismen $\quad 18$

4.4.1 Bestrijdingsmiddelen 19

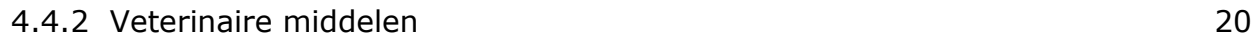

4.5 Resultaten toetsing individuele stoffen aan niet-standaard bodemevertebraten 20

4.5.1 Bestrijdingsmiddelen 20

$\begin{array}{ll}4.5 .2 \text { Veterinaire middelen } & 21\end{array}$

4.6 Resultaten toetsing mengsels van stoffen aan standaard bodemevertebraten 22

4.6.1 Bestrijdingsmiddelen $\quad 22$

4.6.2 Veterinaire middelen $\quad 23$

4.7 Resultaten toetsing mengsels van stoffen aan niet-standaard bodemevertebraten $\quad 23$

4.7.1 Bestrijdingsmiddelen 24

4.7.2 Veterinaire middelen $\quad 24$

$\begin{array}{lll}4.8 & \text { Samenvatting toetsing aan 'indicatieve norm' } & 24\end{array}$

$5 \quad$ Welke emissieroutes spelen een rol bij de gemeten/berekende $\begin{array}{ll}\text { concentraties in mest en bodem? } & 25\end{array}$

$\begin{array}{llr}6 & \text { Discussie } & 28\end{array}$

$\begin{array}{lll}6.1 & \text { Algemeen } & 28\end{array}$

$\begin{array}{lll}6.2 & \text { Tijdsaspect } & 29\end{array}$

6.3 Simultane aanwezigheid van meerdere stoffen: combinatiewerking 29

$\begin{array}{lll}6.4 & \text { Beoordeling risico's } & 30\end{array}$

$\begin{array}{lll}6.5 & \text { Emissieroutes } & 30\end{array}$ 
Bijlage 1 Toelichting op verzamelen toxiciteitswaarden bestrijdingsmiddelen

Bijlage 2 Toxiciteitswaarden voor de bestrijdingsmiddelen gerapporteerd in mest

Bijlage 3 Toxiciteitswaarden voor standaard bodemevertebraten ontleend aan open literatuur en US EPA-database

Bijlage 4 Vergelijk chronische toxiciteit worm (uit NOEC of EC50/10) en MTRsediment

Bijlage 5 Toelichting combinatietoxiciteit en het 'Toxic Units'-concept

Bijlage 6 Berekende Toxic Units op basis van gerapporteerde gehalten in mest en de indicatieve norm

Bijlage 7 Enkele losse observaties 


\section{Verantwoording}

Rapport: 3037

Projectnummer: BO-43-011.01-022

Wageningen Environmental Research (WENR) hecht grote waarde aan de kwaliteit van zijn eindproducten. Een review van de rapporten op wetenschappelijke kwaliteit door een referent maakt standaard onderdeel uit van ons kwaliteitsbeleid.

Akkoord Referent die het rapport heeft beoordeeld,

functie: $\quad$ onderzoeker Environmental Risk Assessment

naam: dr. Louise Wipfler

datum: $\quad 19-10-2020$

Akkoord teamleider voor de inhoud,

naam: Maikel de Potter

datum: $\quad 19-10-2020$ 


\section{Samenvatting}

In het rapport van Buijs en Samwel-Mantingh (2019) wordt een mogelijke relatie gelegd tussen de aanwezigheid van bestrijdingsmiddelen en diergeneesmiddelen in mest van landbouwhuisdieren en de afname van weidevogels t.g.v. een afname in evertebraten (o.a. wormen en insecten) als voedselbron voor deze vogels. Wageningen Environmental Research (WENR) en het College voor de Toelating van Gewasbeschermingsmiddelen en Biociden (Ctgb) hebben eerder geconcludeerd dat het beschreven onderzoek methodologisch onvoldoende is onderbouwd om de relatie tussen de aanwezigheid van individuele bestrijdingsmiddelen en diergeneesmiddelen in mest en de afname van weidevogels door voedselgebrek (o.a. bodem-bewonende wormen en insecten) aan te tonen. Desondanks heeft het onderzoek van Buijs en Samwel-Mantingh (2019) een belangrijke signalerende werking: bestrijdingsmiddelen kunnen zich verspreiden vanuit bedrijven naar het milieu, o.a. via de aankoop van krachtvoer en het gebruik van vliegenverdelgers in de stal. En dit vindt niet alleen plaats binnen conventionele, maar ook binnen biologische bedrijven.

Door Buijs en Samwel-Mantingh (2019) zijn voor 26 mestmonsters, verzameld op 22 verschillende bedrijven, analyseresultaten voor 108 bestrijdingsmiddelen en 21 veterinaire (antiparasitaire) middelen gerapporteerd. De huidige verdiepende analyse heeft getracht te achterhalen hoe betrouwbaar de in het rapport van Buijs en Samwel-Mantingh (2019) gemeten gehalten van middelen zijn, in welke mate gerapporteerde concentraties van de afzonderlijke stoffen individueel en/of in combinatie een risico voor evertebraten in mest en bodem vormen en welke emissieroutes een rol spelen bij de gemeten/berekende concentraties in mest en bodem.

\section{Betrouwbaarheid analyses}

Door de onvoldoende gedetailleerde beschrijving van de gebruikte analysemethodieken - met name van de uitgevoerde validaties - voor bestrijdingsmiddelen (Eurofins) en veterinaire middelen (RIKILT), is het niet mogelijk de betrouwbaarheid van de analyses te beoordelen. Een deel van de door Eurofins gerapporteerde getallen is beneden de opgegeven rapportagegrens en lijkt daarmee hoe dan ook onbetrouwbaar. Daar de toelating van middelen een streng proces is dat gebaseerd is op zeer gedetailleerd gedocumenteerde dossiers, staat dit in aanzienlijk contrast met de beschikbare beschrijving in het rapport van Buijs en Samwel-Mantingh (2019). Op basis van de kwaliteit van deze gegevens is het niet waarschijnlijk dat er een interventie vanuit het beleid kan plaatsvinden.

\section{Mogelijke risico's voor evertebraten}

Desalniettemin betekent dit niet dat er geen signalerende functie van het originele rapport uitgaat en daarom is onderzocht in welke mate gerapporteerde concentraties van de afzonderlijke stoffen individueel en/of in combinatie een risico voor evertebraten in mest en bodem kunnen vormen. Daarbij is gebruikgemaakt van zowel standaard OECD-testen en niet-standaard testen. Van de 975 metingen van bestrijdingsmiddelen in drijf- of vaste mest konden er 906 worden getoetst aan een 'indicatieve norm' voor bodemevertebraten. Overschrijding van de 'indicatieve norm' door individuele stoffen vond slechts in 5 van de 906 getoetste mestmonsters en de daaruit afgeleide gehalten in bodem plaats en werd veroorzaakt door de stoffen epoxiconazool ( 5 keer) en pirimifos-methyl ( 1 keer, in eenzelfde monster waar epoxiconazool ook al overschrijdend was).

Er zijn slechts 3 actieve stoffen waarvoor in een gelimiteerd aantal gevallen is geconstateerd dat er mogelijk sprake is van risico voor bodemevertebraten. Dit betreft de aanwezigheid van epoxiconazool (vijf monsters) en pirimifos-methyl (één monster) in drijfmest en de aanwezigheid van deltamethrin in vaste mest (één monster), die in onverdunde vorm mogelijk enige acute effecten in een keversoort zouden kunnen veroorzaken.

Aannemende dat de gerapporteerde analyseresultaten kloppen, is het niet aannemelijk dat de gemeten stofconcentraties per stof leiden tot minder evertebraten in de bodem, en dus tot minder voedsel voor weidevogels. 
Voor de stoffen cafeïne, DEET, etoxyquin, fenylfenol-2, hexazinon en picaridin waren geen toxiciteitsgegevens beschikbaar, waardoor hier geen uitspraak over een mogelijk risico gedaan kan worden.

De beoordeling van de mengseltoxiciteit resulteerde in zes overschrijdingen van de 'indicatieve norm', waarbij vijf resulteerden in de eerdergenoemde overschrijdingen van individuele stoffen en één nieuw geval werd gevonden (vaste mest bedrijf 24), waarbij de bijdrage van de individuele stoffen samen tot een overschrijding leidde. De analyse van blootstelling aan een combinatie van gemeten stoffen geeft geen aanleiding om de eerdere conclusie over de impact van individuele stoffen bij te stellen.

Doordat de gerapporteerde gehalten van veterinaire middelen alle beneden de rapportagegrens of onbetrouwbaar waren, kan over vrijwel alle veterinaire middelen geen uitspraak met betrekking tot risico's voor bodemleven worden gedaan. Van doramectine en ivermectine kan niet met zekerheid worden gezegd in hoeverre hun aanwezigheid tot effecten op bodemevertebraten zou kunnen leiden en daarmee blijft dit een punt van aandacht.

\section{Emissieroutes}

De gehalten van de gerapporteerde middelen in vaste mest en drijfmest kunnen uit verschillende routes afkomstig zijn. Dat er op verschillende bedrijven veel meer en andere middelen gerapporteerd zijn dan op basis van de reguliere activiteiten op een veeteeltbedrijf verwacht worden, geeft aan dat in ieder geval voor gewasbeschermingsmiddelen externe routes van buiten het bedrijf van belang zijn. Ruwvoer en mengvoer zijn hierbij mogelijke relevante routes. Echter, gezien de weinige overschrijdingen van de indicatieve norm, lijken de hoeveelheden die hiermee gemoeid zijn vanuit het perspectief van de risicobeoordeling niet meteen een aanleiding te vormen voor nader onderzoek.

Daarentegen komt biocide niet via het voer in de mest en spelen hier de routes vanuit dier- en bedrijfsmanagement een belangrijke rol. Ook hier geldt echter dat er voor deze stoffen geen overschrijdingen worden gevonden en dat de hoeveelheden die hiermee gemoeid zijn vanuit het perspectief van de risicobeoordeling niet meteen een aanleiding vormen voor nader onderzoek. Hierbij moet wel de kanttekening gemaakt worden dat het voorkomen van de anti-insectenmiddelen DEET en picaridin in de monsters opvallend is. Deze kennen alleen een officiële toepassing voor humaan gebruik en hierdoor is in de toelating geen milieurisico verondersteld. Het feit dat deze stoffen in mest gedetecteerd zijn, blijkt dat deze aanname aan herziening toe is.

Hoewel er geen directe aanleiding is om op basis van de gegevens uit het rapport van Buijs en Samwel-Mantingh te concluderen dat de genoemde 'blinde vlek' ten aanzien van blootstellingsroutes leidt tot een afname van de evertebraten, adviseren wij om de in dit rapport benoemde onduidelijkheden voor met name veterinaire middelen en middelen die voorheen werden verondersteld geen route naar het milieu te hebben, via wetenschappelijke studies te onderbouwen. 


\section{$1 \quad$ Inleiding}

In het rapport van Buijs en Samwel-Mantingh (2019) wordt een mogelijke relatie gelegd tussen de aanwezigheid van bestrijdingsmiddelen en diergeneesmiddelen in mest van landbouwhuisdieren en de afname van weidevogels ten gevolge van een afname in evertebraten (o.a. wormen en insecten) als voedselbron voor deze vogels. Wageningen Environmental Research (WEnR) en het College voor de Toelating van Gewasbeschermingsmiddelen en Biociden ( $\mathrm{Ctgb}$ ) hebben eerder geconcludeerd dat het beschreven onderzoek methodologisch onvoldoende is onderbouwd om de relatie tussen de aanwezigheid van individuele bestrijdingsmiddelen en diergeneesmiddelen in mest en de afname van weidevogels door voedselgebrek (o.a. bodem-bewonende wormen en insecten) aan te tonen (Brock et al., 2020; Ctgb, 2020). Hierbij moet opgemerkt worden dat het in dit geval gaat om het ecologische risico van de gerapporteerde concentraties van individuele stoffen voor evertebraten in mest en bodem, een belangrijke voedselbron voor weidevogels. Desondanks heeft het onderzoek van Buijs en Samwel-Mantingh (2019) een belangrijke signalerende werking: bestrijdingsmiddelen kunnen zich verspreiden vanuit bedrijven naar het milieu, o.a. via de aankoop van krachtvoer en het gebruik van vliegenverdelgers in de stal. En dit vindt niet alleen plaats binnen conventionele, maar ook binnen biologische bedrijven.

Het is niet uit te sluiten dat de blootstelling aan een mengsel van bestrijdings- en/of diergeneesmiddelen van invertebraten via de mest een effect heeft op het voedsel van weidevogels. Het rapport is echter van onvoldoende kwaliteit om de geschetste causale relaties daadwerkelijk hard te maken. Daardoor is onduidelijk of er met deze route en risico's thans voldoende rekening wordt gehouden, bijvoorbeeld bij de toelatingsprocedures voor gewasbeschermingsmiddelen en biociden. In dit rapport wordt, met bijdrage van het Ctgb, onderzocht of de door Buijs en Samwel-Mantingh (2019) gerapporteerde concentraties van individuele stoffen en mengsels hiervan tot mogelijke risico's voor evertebraten in bodem en mest kunnen leiden. 


\section{$2 \quad$ Projectdoelstelling en methodologie}

Het doel van dit project behelst enerzijds een verdiepende analyse van de door Buijs en SamwelMantingh (2019) gemeten concentraties van individuele stoffen in mest om na te gaan of deze stoffen in combinatie een risico vormen voor evertebraten in mest en bodem, die het voedsel vormen voor veel weidevogels. Hiervoor is tevens een beoordeling nodig van de kwaliteit van de gerapporteerde analyseresultaten. Anderzijds wordt gekeken naar de mogelijke routes (hoe komen deze middelen in de mest terecht?) die een rol kunnen spelen.

Hiervoor zijn drie verschillende onderzoeksvragen gedefinieerd:

1. Hoe betrouwbaar zijn de in het rapport Buijs en Samwel-Mantingh (2019) gemeten gehalten van middelen?

2. In welke mate vormen de in het rapport gemeten concentraties van de afzonderlijke stoffen individueel en/of in combinatie een risico voor evertebraten in mest en bodem?

3. Welke emissieroutes spelen een rol bij de gemeten/berekende concentraties in mest en bodem?

\section{Vraag 1. Hoe betrouwbaar zijn de in het rapport Buijs en Samwel-Mantingh (2019) gemeten gehalten van middelen?}

In eerste instantie zal worden besproken of de laboratoriumanalyses voldoende betrouwbaar zijn. Er is tijdens het onderzoek van de bestrijdingsmiddelen o.a. met niet-gecertificeerde analysemethoden gewerkt en worden waarden gerapporteerd die onder de bepalingsgrenzen van de gebruikte analyses liggen. Indien de chemische analyses van onvoldoende kwaliteit zijn, valt de basis onder een groot deel van het onderzoek van Buijs en Mantingh (2019) weg.

\section{Vraag 2. In welke mate vormen de in het rapport gemeten concentraties van de afzonderlijke stoffen individueel en/of in combinatie een risico voor evertebraten in mest en bodem?}

Omdat het doel van het onderzoek was om na te gaan in hoeverre de stoffen die in mest aanwezig zijn mogelijk tot risico's voor bodemevertebraten leiden, werden de metingen die in voer, hooi en grond zijn uitgevoerd voor dit aspect niet verder in beschouwing genomen. Alleen de concentraties in drijfmest en in vaste mest werden beoordeeld op basis van een nadere toetsing van de aangetroffen concentraties aan beschikbare ecotoxicologische waarden voor evertebraten in bodem en mest. Daarbij is uitgegaan van chronische blootstelling, omdat de mest wordt opgebracht (vaste mest) of ingewerkt (drijfmest) en daarmee enerzijds zowel langdurig aanwezig is als anderzijds zo wijd op het areaal verspreid is dat de evertebraten er altijd wel mee in contact komen. Door deze langdurige blootstelling, resulteert de beoordeling van chronische risico's doorgaans in een lagere acceptabele concentratie dan die voor acute risico's.

Hiervoor zijn toxiciteitsgegevens voor relevante testorganismen (bodem en mest) gezocht in databases. Naast toetsing van de door Buijs en Samwel-Mantingh (2019) gerapporteerde concentraties aan beschikbare ecotox-waarden, wordt de toxiciteit van het mengsel van stoffen beoordeeld op basis van zogenaamde Toxic Units. Dit houdt in dat de concentraties van de gemeten middelen worden genormaliseerd voor toxiciteit, waarna ze opgeteld mogen worden om de combinatiewerking te bepalen. De resultaten van deze evaluatie zijn echter sterk afhankelijk van de hoeveelheid en kwaliteit van de beschikbare gegevens, niet alleen wat betreft de gemeten concentraties, maar ook wat betreft de beschikbare toxiciteitsgegevens. 
Vraag 3. Welke emissieroutes spelen een rol bij de gemeten/berekende concentraties in mest en bodem?

Omdat de verspreiding van gewasbeschermingsmiddelen, biociden en diergeneesmiddelen in het milieu normaliter gerelateerd is aan directe en streng gereguleerde toepassingen van deze middelen, vormt een indirecte route via mest voor sommige van deze stoffen een mogelijke blinde vlek in de toelating (zie hoofdstuk 5). Hoewel uit Stap 2 zou kunnen blijken dat gevonden concentraties geen risico vormen voor mestinsecten en evertebraten in bodem, is het van belang de emissieroutes van de gevonden stoffen in beeld te brengen en de aannemelijkheid van deze routes te duiden. 


\section{Hoe betrouwbaar zijn de in het rapport van Buijs en Samwel- Mantingh (2019) gemeten gehalten van middelen?}

\subsection{Gebruikte laboratoria}

De rapportage van Buijs en Samwel-Mantingh (2019) is gebaseerd op analyseresultaten van twee verschillende laboratoria. De analyse van gewasbeschermingsmiddelen en biociden is uitgevoerd door Eurofins en de analyse van de diergeneesmiddelen is uitgevoerd door het RIKILT. De resultaten van de analyses zullen derhalve per laboratoria separaat besproken worden. In zijn algemeenheid valt echter op dat de exacte methode van bemonsteren, transport en opslag niet goed vermeld is, waardoor er niet kan worden nagegaan of dit de gerapporteerde waarden beïnvloed heeft. Ook is niet duidelijk of er replica- dan wel deelmonsters genomen zijn om inzicht te krijgen in de aanwezige variatie binnen de bemonsterde matrices.

\subsubsection{Eurofins}

Bij Eurofins Lab Zeeuws-Vlaanderen B.V. werden 664 bestrijdingsmiddelen gemeten. Door middel van een pakketanalyse (gaschromatografie en vloeistofchromatografie) werden 661 verschillende pesticiden (inclusief een klein aantal metabolieten) geanalyseerd. Volgens de beschrijving van de extractie-/analysemethode (Buijs en Samwel-Mantingh, paragraaf 3.9) werden 4 verschillende typen monsters (mest, bodem, krachtvoer en kuilvoer) op dezelfde wijze geëxtraheerd en geanalyseerd. De extractie werd in duplo uitgevoerd zonder toevoeging van een interne standaard. Bij een pakket van maar liefst 664 werkzame stoffen en metabolieten lijkt het ook niet haalbaar om een geschikte interne standaard te vinden of om alle 664 verbindingen als referentie toe te voegen.

Omdat het om 4 verschillende typen monsters gaat, is het aannemelijk dat extractie-efficiency en de matrixeffecten per type monster en per component verschillend zijn. Om betrouwbare resultaten te hebben, moeten deze op zijn minst per type matrix, maar bij voorkeur per monster, worden vastgesteld. Echter alle gegevens over de validatie van de methode ontbreken in de rapportage; informatie over de lineariteit van de kalibratiecurve, informatie over het gebruik van externe en/of interne standaarden, blanco (chemicaliën), details omtrent de bepaling van Limit of Detection/Limit of Quantification (LOD/LOQ), informatie omtrent de waarde van het terugvinden van individuele stoffen (recovery) en/of variatie in de bepalingen zijn niet in het rapport te vinden.

In bovengenoemde paragraaf 3.9 wordt gewezen op een verlaging van de ondergrens van de limiet van detectie (Limit Of Detection; LOD) voor de meeste stoffen: van de standaard $10 \mu \mathrm{g} / \mathrm{kg}$ naar $0.1 \mu \mathrm{g} / \mathrm{kg}$. Op welke manier dat wordt bereikt, wordt niet nader aangegeven. In contrast met de genoemde LOD wordt echter in bijlage 10 voor ieder monster een rapportagegrens (Limit Of Quantification; LOQ) van 1, respectievelijk $0.1 \mu \mathrm{g} / \mathrm{kg}$ aangegeven.

De gerapporteerde concentraties zijn vaak lager dan de bijbehorende aangegeven LOQ. Het betreft daarbij zeer verschillende componenten en matrices, bijvoorbeeld monster 18CJ054 van bedrijf 8 en monster 18BR829 van bedrijf 20, beide met 8 getallen onder de LOQ. Van een monster van bedrijf 23 (liquid manure, pag. 163) ontbreekt zowel het monsternummer als de LOQ. Als een LOQ van $0.1 \mathrm{\mu g} / \mathrm{kg}$ wordt verondersteld, zijn 22 van de voor dit monster gerapporteerde concentraties lager dan de rapportagegrens (LOQ).

Voor deze analyses zijn de kwaliteitscriteria niet te achterhalen en omdat er ook met nietgecertificeerde methodes is gewerkt, is het daarom niet duidelijk wat de betrouwbaarheid van de getallen is. Het is daarmee onduidelijk of de gerapporteerde LOQ juist is. Indien dit echter wel het 
geval is, kan het deel van de gerapporteerde resultaten dat onder de LOQ valt als onbetrouwbaar worden aangemerkt.

\subsubsection{RIKILT}

Door het RIKILT in Wageningen werden met behulp van chromatografie de gehalten van

21 belangrijkste antiwormmiddelen (antiparasitaire stoffen) in de mest bepaald. Een beschrijving van de validatie (lineariteit van de kalibratiecurve, gebruik van externe en/of interne standaarden, gebruik van en bepalingen in blanco's, waarde van de individuele 'recoveries' en variatie in resultaten) van de extractie-/analysemethode ontbreekt.

Het feit dat alle monsters in duplo zijn geëxtraheerd, met gebruik van toegevoegde interne standaarden, additie van de antiparasitaire middelen aan 1 van de duplo's, suggereert dat op deze manier de extractie-efficiency en matrixeffect/monster/ component zijn vastgesteld. Het is echter onduidelijk of één algemene interne standaard voor de 21 componenten gebruikt is of dat er per component een specifieke interne standaard is gebruikt.

Rapportagegrenzen zijn vastgesteld per component in $\mu \mathrm{g} / \mathrm{kg}$ vers gewicht, zowel voor als na analyse. Dat suggereert dat de LOQ specifiek per run is vastgesteld. De gebruikte methodiek wordt echter niet beschreven.

De gerapporteerde concentraties zijn altijd of hoger dan de hoogst vastgestelde rapportagegrens voor deze analyse, of worden aangegeven als 'lager dan'. Dat lijkt correct.

Voor ivermectine wordt voor 2 getallen boven de LOQ aangegeven dat er sprake is van grote meetonzekerheid en dat de resultaten onbetrouwbaar zijn.

Door het ontbreken van gedetailleerde informatie omtrent de validatie van de methode kan niet worden beoordeeld in hoeverre de resultaten van de chemische analyses betrouwbaar zijn.

\subsection{Conclusie}

De verdiepende analyse naar de gerapporteerde getallen door Buijs en Samwel-Mantingh (2019) laat enkele belangrijke onvolkomenheden zien. Zo zijn veel door Eurofins gemeten gehalten beneden de opgegeven rapportagegrens waardoor ze niet als betrouwbaar kunnen worden beschouwd.

De door Buijs en Samwel-Mantingh (2019) gegeven beschrijving van de door Eurofins en RIKILT uitgevoerde analyses is verder onvoldoende gedetailleerd, met name waar het de validatie van de analyses betreft. Hierdoor is het niet mogelijk de betrouwbaarheid te beoordelen en een goede risicoanalyse uit te voeren. Hiermee valt de basis onder de conclusies van het rapport weg en is het niet waarschijnlijk dat op grond van de kwaliteit van deze getallen verwacht kan worden dat er een interventie vanuit het beleid zal plaatsvinden. 


\section{$4 \quad$ In welke mate vormen de in het rapport gerapporteerde concentraties van de afzonderlijke stoffen individueel en/of in combinatie een risico voor evertebraten in mest en bodem?}

\subsection{Verzamelen toxiciteitsgegevens}

De evertebraten worden blootgesteld doordat typische mest-gerelateerde organismen (zoals vliegen en mestkevers) direct contact maken met de verse mest in het veld of doordat de mest in de stal wordt verzameld en daarna op het land uitgereden of ingewerkt wordt. Daardoor worden de risico's die de aanwezigheid van gewasbeschermingsmiddelen, biociden en veterinaire middelen in mest veroorzaken voor evertebraten beoordeeld door enerzijds de gerapporteerde concentraties in mest direct te vergelijken met toxiciteitswaarden voor typische mest-gerelateerde organismen en anderzijds door (berekende) concentraties in bodem te vergelijken met toxiciteitsgegevens voor bodemevertebraten. In de volgende paragrafen wordt beschreven welke toxiciteitsgegevens zijn gebruikt en hoe de concentraties in de bodem zijn berekend.

\subsubsection{Bestrijdingsmiddelen (inclusief biociden)}

\subsubsection{Ecotoxicologische toetsen voor bodemorganismen als onderdeel van de toelating}

In deze groep vallen de middelen met een pesticide en biocide werking. Deze groep middelen wordt hierna aangeduid met Bestrijdingsmiddelen. In de toelating van deze middelen worden normen afgeleid op basis van ecotoxicologische toetsen met zogenaamde standaardtoetsorganismen. Dit betreft voor gewasbeschermingsmiddelen een worm (Eisenia foetida of Eisenia andrei). Terwijl voor biociden tevens een springstaart (Folsomia candida), een bodemmijt (Hypoaspis aculeifer), een terrestrische niet-doelwit plant en microbiële organismen die een rol spelen bij de omzetting van stikstof gebruikt worden. Omdat in dit rapport de focus ligt op de risico's voor evertebraten, de ongewervelde organismen die kunnen dienen als voedsel voor weidevogels, zijn de gegevens met betrekking op micro-organismen die een rol spelen bij de omzetting van stikstof en terrestrische planten buiten beschouwing gelaten.

Bij de toelating van bestrijdingsmiddelen zijn met betrekking tot chronische risico's voor bodemorganismen derhalve de volgende gegevens relevant:

- Subletale toxiciteit voor de worm (Eisenia foetida of Eisenia andrei). De test dient te zijn uitgevoerd volgens OECD-richtlijn 222 (OECD 222, 2016) en er dient informatie te worden gegeven over effecten op groei, reproductie en gedrag. Relevante eindpunten zijn EC10 of EC20 (effect concentratie waarbij respectievelijk 10 of $20 \%$ effect gevonden wordt op de onderzochte parameter), in combinatie met een NOEC (No Observed Effect Concentration = test concentratie waarbij geen effecten gevonden zijn).

- Toetsen op de springstaart (Folsomia candida) en de mijt (Hypoaspis aculeifer) (OECD 232, 2008) voor middelen die rechtstreeks op grond worden toegepast tijdens de behandeling. Als tijdens de risicobeoordeling voor gewasbeschermingsmiddelen die op het gewas worden toegepast mogelijke risico's voor niet-doelwit evertebraten zijn geïdentificeerd op basis van deze OECD-studies, kunnen additionele gegevens voor andere evertebraten dan de worm vereist zijn. Hoewel aangegeven wordt dat hiervoor gegevens voor de sluipwesp Aphidius rhopalosiphi en de roofmijt Typhlodromus pyri kunnen worden gebruikt, moet hierbij opgemerkt worden dat de relevante eindpunten hier 
doorgaans LR50 (lethal rate) en ER50 (effect rate) waarden betreffen, die doordat ze een eenheid van 'hoeveelheid per oppervlak hebben' niet vergelijkbaar zijn met de eerdergenoemde waarden die een eenheid van 'hoeveelheid middel per kg grond' kennen. Waarmee de praktische toepasbaarheid van deze additie vooralsnog gelimiteerd is.

Als er sprake is van een mogelijke blootstelling van het terrestrische compartiment of als er een mogelijk risico wordt gesignaleerd vanuit acute toxiciteitstesten, zijn bij de toelating van biociden met betrekking tot risico's voor bodemorganismen gegevens uit een of meerdere van de volgende testen relevant (ECHA, 2017a, b):

- Reproductietoxiciteit voor de regenworm (Lumbricina). De test dient te zijn uitgevoerd volgens OECD 222 (2016) of ISO 11268-1 (2012). De relevante eindpunten zijn een ECx (EC10 of EC50) in combinatie met een NOEC.

- Reproductietoxiciteit voor en overleving van potwormen (Enchytraeidae). De test dient te zijn uitgevoerd volgens OECD 220 (2016) of ISO 16387 (2014). De relevante eindpunten zijn een ECX (EC10 of EC50) in combinatie met een NOEC.

Voor stoffen met een insecticide werking of stoffen waarvan wordt aangenomen dat ze de vervellingshormonen van insecten verstoren of dat ze andere effecten hebben op de groei en ontwikkeling van insecten, is een geleedpotige de voorkeurstestsoort:

- Hypoaspis (Geolaelaps) aculeifer (mijt), uitgevoerd volgens OECD 226 (2016);

- Folsomia candida (springstaart), uitgevoerd volgens OECD 232 (2016) of ISO 11267 (2014);

- Aleochara bilineata (kortschildkever), Poecilus cupreus (loopkever) of Pardosa sp. (wolfspin) volgens de IOBC-richtlijn (2000).

\subsubsection{Gevolgde methode bij het verzamelen van toxiciteitsgegevens voor standaardorganismen}

Voor alle werkzame stoffen die in mest werden aangetroffen, werden indien mogelijk toxiciteitsgegevens verzameld voor de binnen de (EU) toelating gebruikte standaard bodemorganismen: de worm Eisenia foetida, de springstaart Folsomia candida en de mijt Hypoaspis aculeifer.

Hiertoe werden de volgende stappen gevolgd (zie ook Figuur 1). Voor elke werkzame stof gerapporteerd door Buijs en Samwel-Mantingh (2019) is gecontroleerd of er een 'EFSA Conclusion' of 'EFSA Opinion' beschikbaar is (http://www.efsa.europa.eu/en/publications). Hierbij zijn de instructies gevolgd zoals beschreven door KEMI (2017). Indien er geen 'EFSA Conclusion' beschikbaar was, bestond de volgende stap uit raadpleging van de EU Pesticide Database (zie Figuur 1), waarbij voor elke gevonden stof werd gecontroleerd of er in de sectie 'review report' documenten werden genoemd die de gezochte gegevens bevatten (https://ec.europa.eu/food/plant/pesticides/eu-pesticidesdatabase/public/?event=homepage\&language $=\mathrm{EN}$ ).

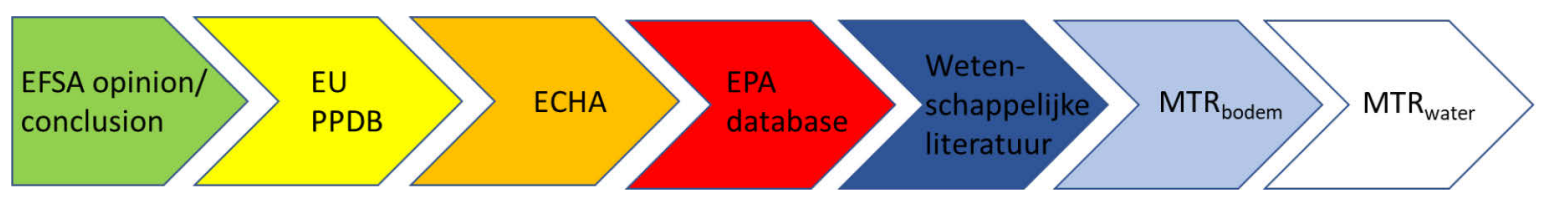

Figuur 1 Schematische aanpak van het verzamelen van de gegevens.

Indien geen toxiciteitsgegevens beschikbaar waren, werd gezocht in hoeverre het Europees Agentschap voor Chemische Stoffen (ECHA) bodemgegevens (Predicted No Effect Concentrations; PNEC) voor de stof had afgeleid. Daarnaast werd gecontroleerd in hoeverre de 'Pesticides Properties Database' (https://sitem.herts.ac.uk/aeru/ppdb/en/index.htm) gegevens bevatte.

Voor stoffen waarvoor in bovengenoemde bronnen geen gegevens of gegevens voor slechts één soort werden gevonden, werd de U.S. EPA database geraadpleegd om gegevens voor één of meer van de genoemde standaardsoorten te achterhalen. 
Indien hierna nog steeds geen toxiciteitsgegevens beschikbaar waren, werd - waar mogelijk - de MTR

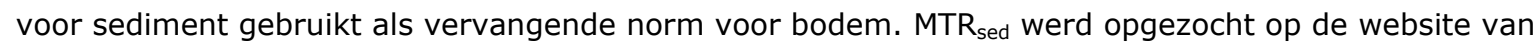
het RIVM voor risico's van stoffen (https://rvszoeksysteem.rivm.nl/). Indien ook de MTR sed niet beschikbaar was, werd uit de MTR voor water (opgeloste stof) een MTR voor sediment geschat als $\mathrm{MTR}_{\text {sed }}=\mathrm{MTR}_{\text {water }} * \mathrm{~K}_{\mathrm{oc}} * \mathrm{~F}_{\mathrm{oc}}$, waarbij werd aangenomen dat het organische koolstofgehalte van bodem $\mathrm{F}_{\mathrm{OC}}=0.043 \mathrm{~kg} \mathrm{OC} / \mathrm{kg}$ bodem (Reijneveld et al., 2009) en $\mathrm{K}_{\mathrm{oc}}$ de sorptie constante aan organische koolstof van de stof is.

Hierbij moet worden opgemerkt dat in het geval er meerdere toxiciteitswaarden voor één soort beschikbaar waren, de waarde uit het officiële toelatingsdossier gebruikt werd. Dit omdat deze waarde een gegarandeerde kwaliteitscontrole ondergaan heeft, terwijl dat voor waarden in de open literatuur doorgaans niet aantoonbaar het geval is.

\subsubsection{Niet-standaard bodemorganismen}

Er zijn studies met verschillende soorten niet-standaard organismen beschikbaar om te beoordelen of de gerapporteerde gehalten aan middelen een mogelijk risico vormen. Deze groep bevat onder andere verschillende kevers die erg algemeen kunnen voorkomen in het weidelandschap. Deze kevers, en met name hun larvale stadia, dienen als voedsel voor vogels en zoogdieren (mollen, dassen). Om deze reden is getracht voor deze groep ook te toetsen in hoeverre de aangetroffen bestrijdingsmiddelen mogelijk een risico vormen.

$\mathrm{Er}$ is in de wetenschappelijke literatuur gezocht naar gegevens met betrekking tot de Rozenkever of Johanneskever (Phyllopertha horticola), waarvan de larven in grasland leven; de Junikever (Amphimallon solstitiale), waarvan de larven in bodem leven en worteldelen eten; langpootmuggen (Tipulidae), die erg algemeen zijn en waarvan de larven (emelten) in grasland leven; en de Meikever (Melolontha melolontha), waarvan de larven in de bodem leven. Voor deze 4 soorten is gezocht in Scopus met zoektermen als 'soortnaam AND (toxic* OR pestic*)' en 'soil AND larvae AND pestic*'.

\subsubsection{Veterinaire middelen}

Voor de door Buijs en Samwel-Mantingh gerapporteerde veterinaire middelen (antiparasitaire middelen) die door het RIKILT zijn gemeten (Bijlagen 2 en 3 van Buijs en Samwel-Mantingh, 2019), is getracht informatie te vergaren omtrent hun toxiciteit voor standaard en niet-standaard bodemorganismen. Hiervoor is contact gezocht met het College ter Beoordeling van Geneesmiddelen (CBG) die eenzelfde functie vervullen voor deze stofgroep als het CTGB vervuld voor gewasbeschermingsmiddelen en biociden en tevens is er in de openbare literatuur gezocht op de zoektermen 'veterinary parasiticides', 'parasitica', 'pesticides', 'insecticides', 'fungicides', 'insects', 'Coleoptera', 'Diptera', 'Aphodius', 'dung', 'manure', 'Onthophagus', 'Scarabidae', 'Scatophaga', 'cattle', 'NOEC', 'EC50', 'LC50', 'OECD', 'environmental risk assessment', in combinatie met de namen van de gerapporteerde veterinaire middelen (ivermectine, moxidectine, dora-mectine, fenbendazole etc.).

\subsection{Afleiding gebruikte toetsconcentraties}

\subsubsection{Beoordeling werking van individuele stoffen}

Om tot een risicoschatting te komen, is een norm nodig waarmee de blootstellingsconcentraties worden vergeleken. Deze norm wordt normaliter afgeleid door de laagste chronische toxiciteitswaarde te delen door een zogenaamde 'beoordelingsfactor' (normaliter een factor 10). Als de gemeten concentraties boven deze norm liggen, is er mogelijk sprake van een risico. Met getallen voor drie standaardtoetssoorten aanwezig, geeft dit een waarde die beschermend zou moeten zijn voor de overige evertebraten die niet getest zijn. Als er echter maar één standaardtoetsgetal voorradig is, is het niet duidelijk of de norm wel van de gevoeligste waarde wordt afgeleid en deze daarmee beschermend genoeg is. Derhalve is er in deze rapportage voor gekozen om een 'indicatieve norm' af te leiden die rekening houdt met de dichtheid van de beschikbare data. De gerapporteerde gehalten van bestrijdingsmiddelen (metingen Eurofins) zijn getoetst aan deze 'indicatieve norm' voor effecten op bodemleven. De afleiding van deze indicatieve norm wordt hierna toegelicht. 
Het toetsen van de gevonden gehalten van bestrijdingsmiddelen aan effectconcentraties voor andere (niet-standaard) bodemorganismen (pestorganismen en/of hun larven: de Johanneskever Phyllopertha horticola, de Junikever Amphimallon solstitiale, de Langpootmug Tipulidae, en de meikever Melolontha melolontha) bleek helaas niet mogelijk, omdat voor vrijwel geen bestrijdingsmiddelen toxiciteitswaarden voor deze organismen in de openbare literatuur beschikbaar waren.

De 'indicatieve norm' voor effecten op bodemleven werd geschat op basis van de beschikbare toxiciteitsgegevens voor de standaard bodemorganismen (de worm Eisenia foetida, de springstaart Folsomia candida en de mijt Hypoaspis aculeifer). De 'norm' werd als volgt afgeleid:

1. Indien chronische NOEC- en/of EC10-waarden beschikbaar waren voor zowel E. foetida als voor F. candida en/of $H$. aculeifer, dan werd de laagste NOEC/10 of EC10/10 gebruikt als 'norm'.

2. Indien slechts voor een enkele soort een chronische NOEC en/of EC10 beschikbaar was, dan werd NOEC/100 of EC10/100 gebruikt als 'norm'.

3. Indien voor een standaard bodemorganisme geen chronische toxiciteitswaarden beschikbaar waren, werd als benadering voor de chronische NOEC en/of EC10 gebruikgemaakt van acute EC50/10 als schatting van de chronische NOEC en/of EC10.

4. Als slechts voor een enkele standaard soort een acute EC50 beschikbaar was, dan werd de 'norm' geschat als EC50/1000.

Toetsing van de gerapporteerde gehalten van veterinaire middelen aan effectconcentraties voor standaard bodemorganismen (de regenworm Eisenia foetida, de springstaart Folsomia candida en de mijt Hypoaspis aculeifer) bleek echter niet mogelijk, omdat voor deze soorten geen toxiciteitsgegevens werden gevonden. De gerapporteerde gehalten aan veterinaire middelen (metingen RIKILT) konden wel getoetst worden aan effectconcentraties voor enkele mestorganismen.

\subsubsection{Beoordeling combinatiewerking van mengsels van stoffen}

Om een inschatting te maken van de mogelijke combinatie-effecten van middelen op bodemevertebraten, wordt het concept van 'concentratie-additie' gehanteerd. Hierbij wordt aangenomen dat elke stof, ongeacht zijn werkingsmechanisme, bijdraagt aan de totale toxiciteit naar rato van zijn aanwezigheid, uitgedrukt als de verhouding tussen concentratie en norm. Concreet betekent dit dat de verhouding tussen concentratie en norm zoals die voor elke stof afzonderlijk wordt bepaald (zie paragraaf hierboven), wordt gesommeerd over alle aangetroffen stoffen.

Strikt genomen kan het 'Toxic Unit' concept alleen worden toegepast als de berekening van het aantal Toxic Units voor alle stoffen is gebaseerd op hetzelfde organisme en hetzelfde type toxiciteit (acuut of chronisch). Dit is hier niet het geval, omdat de 'norm' voor bodemevertebraten voor de ene stof gebaseerd zal zijn op toxiciteit voor de worm en voor een andere stof mogelijk gebaseerd is op de toxiciteit voor de springstaart (als dat het gevoeligste organisme is voor die andere stof). Door Toxic Units op basis van (geschatte) chronische toxiciteit voor elke afzonderlijke stof te baseren op de (geschatte) chronische toxiciteit van het gevoeligste organisme, wordt een hogere mengseltoxiciteit berekend dan wanneer voor alle stoffen dezelfde soort gebruikt zou worden, wat in dit rapport voor een strengere (conservatieve) beoordeling zorgt.

Een nadere verklaring van het 'Toxic Unit'-concept is te vinden in het rapport van Weltje (et al., 1995), dat een goed overzicht geeft van de aannames en methodieken die voor ons werk relevant zijn. Het relevantste deel van dit rapport is overgenomen en te vinden in Bijlage 5.

Bij de berekening van het aantal Toxic Units wordt als concentratie $\mathrm{Ci}$, de voor iedere stof i berekende concentratie in bodem, gehanteerd. Als effectconcentratie ECx, i van stof i wordt de 'norm voor bodemevertebraten' (berekend volgens de in paragraaf 4.2.1 beschreven methodiek) genomen. De berekening geeft een indruk in hoeverre de aanwezigheid van meerdere stoffen leidt tot een gezamenlijke toxische belasting die mogelijk leidt tot chronische effecten op bodemevertebraten in het algemeen. 


\subsection{Berekening blootstelling uit de gerapporteerde meetgegevens}

Om tot een blootstellingsconcentratie in grond te komen, werden de inhoudelijke aannames van de risicobeoordeling volgens de Biocidal Products Regulation (ECHA, 2017) gevolgd. Aangenomen werd dat de mest wordt uitgereden en wordt ingewerkt in de grond, wat tot enige verdunning van de stoffen leidt. Hierbij wordt aangenomen dat de inwerkdiepte van mest bij grasland $5 \mathrm{~cm}$ bedraagt en $20 \mathrm{~cm}$ voor akkerbouw ('arable land'). Voor inwerken van drijfmest is derhalve in de berekeningen een inwerkdiepte van $5 \mathrm{~cm}$ verondersteld, voor inwerken van vaste mest is een inwerkdiepte van $20 \mathrm{~cm}$ verondersteld.

Een inwerkdiepte van $5 \mathrm{~cm}$ correspondeert met een volume grond van $0.05 \times 100 \times 100 \mathrm{~m}^{3}$ per hectare $\left(500 \mathrm{~m}^{3} / \mathrm{ha}\right)$, wat bij een veronderstelde standaard droge bulkdichtheid van $1500 \mathrm{~kg} / \mathrm{m}^{3}$ (zoals ook gebruikt in de risicobeoordeling voor gewasbeschermingsmiddelen en biociden) leidt tot een hoeveelheid van 750 ton bodem/ha die direct in contact komt met ingebrachte mest. Voor een inwerkdiepte van $20 \mathrm{~cm}$ betreft dit dan 3000 ton bodem/ha.

De hoeveelheid uitgereden mest wordt in de ECHA-risicobeoordeling (ECHA, 2017) gerelateerd aan het stikstofgehalte van de mest (jaarlijkse geoorloofde stikstofbelasting van $170 \mathrm{~kg} \mathrm{~N} / \mathrm{ha}$ per jaar). Met een gemiddelde stikstofproductie van $144 \mathrm{~kg} / \mathrm{dier} / \mathrm{jaar}$ en een gemiddelde mestproductie van 28000 kg/dier/jaar komt dit neer op uitrijden van circa 34 ton mest/ha/jaar (Dierlijke mest en mineralen, 2017, CBS). Buijs en Samwel-Mantingh (2019, pagina 31) hanteren zelf een geschatte hoeveelheid mest van 10-50 ton/ha/jaar. We veronderstellen daarom hier een worstcasesituatie, waarbij 50 ton mest/ha/jaar wordt uitgereden.

Als 50 ton (drijf)mest per ha per jaar wordt uitgereden, leidt dit tot een verdunning van de mest in de grond met een factor 15 (inwerkdiepte $5 \mathrm{~cm} ; 750$ ton bodem/ha gedeeld door 50 ton (drijfmest/ha)). Voor stalmest, met een inwerkdiepte van $20 \mathrm{~cm}$, wordt vanwege deze 4x grotere diepte bij uitrijden op akkers verdunning met een factor 60 verondersteld.

Daarnaast wordt voor vaste mest verondersteld dat typische mestorganismen direct worden blootgesteld aan onverdunde mest. Dit zal met name optreden op mestvaalten en dergelijke, waar de stalmest enige tijd blijft liggen. De uitkomst van deze risicobeoordeling kan ook dienen als indicatie voor het risico voor mestorganismen van verse mest uitgescheiden op het land (koeienvlaaien). Deze verse weidemest is in het rapport van Buijs en Samwel-Mantingh (2019) niet bemonsterd voor meting van de gehalten aan werkzame stoffen. De gehalten in stalmest staan derhalve model voor de gehalten in verse koeienvlaaien.

De door Eurofins en RIKILT gerapporteerde gehalten beneden de rapportagegrens van de betreffende stof $(<X \mu \mathrm{g} / \mathrm{kg})$ zijn in de berekeningen geïnterpreteerd als 'de betreffende stof is niet aangetroffen' en het gehalte is gelijk aan nul verondersteld.

\subsection{Resultaten toetsing individuele stoffen aan standaard bodemorganismen}

In totaal waren er 108 gerapporteerde bestrijdingsmiddelen en 21 gerapporteerde veterinaire middelen. Voor standaard bodemevertebraten werd voor 96 van de 108 gerapporteerde bestrijdingsmiddelen een toxiciteitswaarde gevonden voor ten minste 1 van de standaard organismen. Voor 6 van de overgebleven 12 bestrijdingsmiddelen werd een MTR voor sediment berekend uit een MTR voor water. Voor 6 bestrijdingsmiddelen werden geen toxiciteitsgegevens voor standaard bodemevertebraten gevonden (niet toegelaten of gegevens niet vereist vanwege gering geschatte kans op blootstelling in de bodem). Voor geen enkele van de gerapporteerde veterinaire middelen werden toxiciteitsgegevens voor standaard bodemevertebraten gevonden. 
De voor bodem berekende, dan wel rechtstreeks in mest gemeten concentraties bestrijdingsmiddelen en veterinaire middelen zijn vergeleken met de 'indicatieve norm' op basis van de chronische toxiciteit voor standaard bodemorganismen. In deze paragraaf gebeurt dat per individuele stof. Wat de gelijktijdige aanwezigheid van meerdere stoffen in mest van eenzelfde bedrijf mogelijk betekent voor het risico voor bodemevertebraten (combinatietoxiciteit) wordt behandeld in paragraaf 4.6.

\subsubsection{Bestrijdingsmiddelen}

Er zijn in totaal 975 metingen in drijfmest of vaste mest waaruit een concentratie in bodem is berekend. Van de 975 berekende concentraties in de bodem konden er 69 niet worden getoetst aan de norm voor bodemevertebraten, omdat die voor de betreffende stoffen niet beschikbaar was (41 metingen) of omdat de meting resulteerde in een gehalte beneden de rapportagegrens (28 metingen) en de stof dus niet aangetoond kon worden. Bij deze 69 niet-getoetste concentraties betreft het metingen van de 15 stoffen in Tabel 1.

Voor de 6 stoffen caffeïne, DEET (N, N-diethyl-meta-toluamide), etoxyquin, fenylfenol-2, hexazinon en picaridin konden geen normen voor bodemleven worden gevonden en/of geschat omdat de hiervoor benodigde gegevens ontbraken.

Tabel 1 Bestrijdingsmiddelen die niet getoetst konden worden.

\begin{tabular}{ll} 
Stof & Aantal metingen in drijf- of vaste mest \\
Caffeïne & $11^{\mathrm{A}}$ \\
\hline Glyphosate & 8 \\
\hline Glufosinate & 15 \\
\hline Glufosinate-ammonium & 4 \\
\hline DEET & $5^{\mathrm{A}}$ \\
\hline Fenylfenol-2 & $5^{\mathrm{A}}$ \\
\hline Hexazinon & $1^{\mathrm{A}}$ \\
\hline Picaridin & $2^{\mathrm{A}}$ \\
\hline AMPA & $1^{4^{\mathrm{A}}}$ \\
\hline Etoxyquin & $4^{\mathrm{A}}$ \\
\hline A Metingen niet getoetst aan bodemnorm omdat er geen waarde voor de norm beschikbaar was; de resterende, niet gemarkeerde metingen zijn
\end{tabular}

Van de in bodem berekende concentraties werden er 906 getoetst aan de 'indicatieve norm' voor bodemevertebraten. 900 van de 906 getoetste concentraties waren beneden de norm. Alleen van epoxiconazole (op 5 bedrijven) en pirimifos-methyl werd de norm overschreden. De 'top 10' van stoffen met de hoogste ratio tussen blootstellingsconcentratie en norm voor bodemevertebraten is in onderstaande tabel weergegeven. Let op: Als de Toxic Unit kleiner is dan 1, is er geen overschrijding van de norm.

Er staan 5 verschillende stoffen in de 'top 10': epoxiconazole (op 6 bedrijven), pirimifos-methyl, Ethoxyquin, mefosfolan en Picoxystrobin (alle 1 keer). 
Tabel 2 Top-10 van voorvallen uit de 906 toetsingen waarbij de indicatieve norm voor bodemorganismen het dichtste benaderd werd $(T U=1)$. Cursieve waarden $T U<1$, vetgedrukte waarden TU>1.

\begin{tabular}{lllr} 
Stofnaam & Bedrijf & Matrix & Toxic Unit \\
Picoxystrobin & 3 & Drijfmest & 0.4682470 \\
\hline Mefosfolan & 23 & Vaste mest & 0.7216584 \\
\hline Ethoxyquin & 20 & Drijfmest & 0.8395820 \\
\hline Epoxiconazole & 24 & Vaste mest & 0.9384921 \\
\hline Epoxiconazole & 1 & Vaste mest & $\mathbf{1 . 0 1 5 0 1 6 1}$ \\
\hline Epoxiconazole & 4 & Drijfmest & $\mathbf{1 . 2 0 7 8 1 8 2}$ \\
\hline Epoxiconazole & 17 & Vaste mest & $\mathbf{2 . 1 0 3 1 7 4 6}$ \\
\hline Epoxiconazole & 3 & Drijfmest & $\mathbf{4 . 1 6 8 8 4 2 1}$ \\
\hline Pirimifos-methyl & 25 & Drijfmest & $\mathbf{4 . 4 3 4 8 7 2 9}$ \\
\hline Epoxiconazole & 25 & Drijfmest & $\mathbf{1 5 . 8 1 5 3 5 2 8}$
\end{tabular}

\subsubsection{Veterinaire middelen}

Voor de standaard bodemevertebraten (Eisenia foetida, Folsomia candida, Hypoaspis aculeifer) werden geen toxiciteitsgegevens voor veterinaire middelen in toelatingsdossiers gevonden. Navraag bij het College ter Beoordeling van Geneesmiddelen, dat de toelating van veterinaire geneesmiddelen 'beheert', leverde geen toegang tot aanvullende gegevens voor standaard bodemevertebraten op. Door het ontbreken van gegevens met betrekking tot de toxiciteit van veterinaire middelen voor standaard bodemorganismen is toetsing niet mogelijk.

\subsection{Resultaten toetsing individuele stoffen aan niet- standaard bodemevertebraten}

De rechtstreeks in mest gemeten concentraties bestrijdingsmiddelen en veterinaire middelen worden vergeleken met de 'indicatieve norm' op basis van (geschatte) chronische toxiciteit voor nietstandaard bodemevertebraten. In deze paragraaf gebeurt dat per individuele stof. Wat de gelijktijdige aanwezigheid van meerdere stoffen in mest van eenzelfde bedrijf mogelijk betekent voor het risico voor bodemleven (combinatietoxiciteit) wordt behandeld in paragraaf 4.6 en 4.7.

\subsubsection{Bestrijdingsmiddelen}

Voor niet-standaard bodemevertebraten werden voor drie van de gerapporteerde bestrijdingsmiddelen (cyfluthrin, cypermethrin en deltamethrin) toxiciteitswaarden gevonden (Tabel 3).

Tabel 3 Toxiciteitswaarden van bestrijdingsmiddelen gerapporteerd in vaste en/of drijfmest voor niet-standaard bodemorganismen.

\begin{tabular}{|c|c|c|c|c|c|}
\hline Stof & Soort & $\begin{array}{l}\text { Chronische NOEC } \\
\text { (ug/kg) }\end{array}$ & $\begin{array}{l}\text { Acute EC50 } \\
\text { (ug/kg vers } \\
\text { gewicht) }\end{array}$ & Eindpunt & Referentie \\
\hline Cypermethrin & Hister spp. & - & 60 & Overleven & Vale et al., 2004 \\
\hline Cyfluthrin & Ontophagus gazella & - & 40 & Overleven & Vale et al., 2004 \\
\hline
\end{tabular}

- = geen waarde gevonden

Op één van de bedrijven zijn cypermethrin en deltamethrin gevonden in vaste mest van 0.10 en $2.85 \mathrm{ug} / \mathrm{kg}$ vers gewicht, die respectievelijk tot gehalten van $0.002 \mu \mathrm{g} / \mathrm{kg}$ vers gewicht en $0.76 \mu \mathrm{g} / \mathrm{kg}$ vers gewicht in grond leidden. De acute EC50 (overleven) voor de spiegelkever Hister spp. met betrekking tot deze stoffen bedraagt 60 en $10 \mu \mathrm{g} / \mathrm{kg}$ verse mest resp. Cypermethrin was derhalve in 
vaste mest aanwezig in concentraties waarvan geen risico's verwacht mogen worden op larven van deze kever. Echter, Deltamethrin was op dit bedrijf aanwezig in vaste mest in concentraties die, hoewel onder de EC50 liggen, mogelijk wel acute effecten in deze keversoort zouden kunnen veroorzaken als deze concentraties in verse koeienvlaaien op het land gevonden konden worden.

Cyfluthrin is alleen in een drijfmestmonster gerapporteerd, wat tot een geschatte concentratie in de bodem van $0.01 \mathrm{ug} / \mathrm{kg}$ vers gewicht resulteert. Hierdoor worden er geen risico's verwacht voor larven van deze kever. Het onderzoek naar toxiciteitswaarden voor de Meikever, Johanneskever, Junikever en Langpootmuggen leverde geen bruikbare getallen op.

\subsubsection{Veterinaire middelen}

Van de veterinaire middelen waarvoor toxiciteitsgegevens voor mestorganismen beschikbaar zijn (doramectine, fenbendazole, ivermectine en moxidectine), zijn de gehalten in vaste mest alle beneden de rapportagegrens. Een uitzondering vormen twee metingen voor ivermectine, die hoger zijn dan de rapportagegrens. Van deze gerapporteerde getallen wordt echter aangegeven dat zij wegens de grote meetonzekerheid indicatief en minder betrouwbaar zijn.

De meeste toxiciteitswaarden die werden gevonden, hebben betrekking op niet-Europese soorten. De interessantste soorten betreffen twee vliegen en een kever die in Europa voorkomen. De strontvlieg Scatophaga stercoraria komt zeer algemeen voor in Europa, evenals de vlieg Musca autumnalis. Daarnaast zijn er relatief veel gegevens gevonden voor de mestkever Aphodius constans, die in diverse Europese landen voorkomt. Indien een waarde voor een van deze drie soorten beschikbaar was, werd daaraan de voorkeur gegeven en werd de waarde voor de gevoeligste soort gebruikt. Indien geen waarden voor een van deze drie soorten beschikbaar waren, werd de waarde voor de gevoeligste soort gebruikt. Indien meerdere waarden voor deze soort beschikbaar waren, is de laagste waarde opgenomen. Uiteindelijk zijn waarden gebruikt voor de vlieg Musca autumnalis, de gele of gouden mestvlieg Scatophaga stercoraria, de mestkever Aphodius constans, de steekvlieg Haematobia irritans en de bruine mestkever Onthophagus gazella.

In onderstaande tabel is, indien waarden voor meerdere soorten beschikbaar waren, de waarde voor de gevoeligste soort gebruikt. Indien meerdere waarden voor deze soort beschikbaar waren, is de laagste waarde opgenomen.

Voor doramectine ligt de rapportagegrens in vaste mest op $1 \mu \mathrm{g} / \mathrm{kg}$, terwijl de chronische toxiciteitswaarde op $2.4 \mu \mathrm{g} / \mathrm{kg}$ ligt (Tabel 4). Dit betekent dat concentraties die net niet gemeten kunnen worden, mogelijk in de buurt van niveaus liggen die tot chronische risico's kunnen leiden. Dit geldt ook voor de stoffen ivermectine en moxidectine, maar met de beschikbare gegevens kan hier op dit moment geen verdere zekerheid over gegeven worden. Hoewel voor ivermectine in twee monsters relatief hoge gehalten ( 2 resp. $12 \mu \mathrm{g} / \mathrm{kg}$ ) gerapporteerd worden, is ook aangegeven dat er sprake was van grote onbetrouwbaarheid in de verkregen resultaten. Interpretatie van deze specifieke gehalten in termen van mogelijk risico is daarom niet goed mogelijk.

Hoewel de rapportagegrens voor fenbendazole in vaste mest ook op $1 \mu \mathrm{g} / \mathrm{kg}$ ligt, bedraagt de chronische toxiciteitswaarde $770 \mu \mathrm{g} / \mathrm{kg}$ (Tabel 4). De gehalten in vaste mest zijn dus beduidend lager dan het niveau waarop een chronisch effect kan worden verwacht. 
Tabel 4 Toxiciteitswaarden voor veterinaire middelen voor niet-standaard bodemevertebraten.

\begin{tabular}{|c|c|c|c|c|c|c|}
\hline Stof & Soort & Familie & $\begin{array}{l}\text { Chronische } \\
\text { NOEC } \\
(\mu g / \mathrm{kg})\end{array}$ & $\begin{array}{l}\text { Acute EC50 } \\
(\mu g / k g)\end{array}$ & Eindpunt & Referentie \\
\hline \multirow{2}{*}{ Ivermectine } & $\begin{array}{l}\text { Scatophaga } \\
\text { stercoraria }\end{array}$ & Diptera & & 0.051 & Sterfte & $\begin{array}{l}\text { Köveccses \& } \\
\text { Marcogliese, } 2005\end{array}$ \\
\hline & Saltella sphondylii & Diptera & & 0.199 & Emergence & $\begin{array}{l}\text { Blanckenhorn et al., } \\
2013\end{array}$ \\
\hline \multirow[t]{2}{*}{ Moxidectine } & Aphodius constans & Coleoptera & & $4000-5400$ & & Hempel et al., 2006 \\
\hline & Haematobia irritans & Diptera & 64 & & & Fort Dodge, 1997 \\
\hline Fenbendazole & $\begin{array}{l}\text { Onthophagus } \\
\text { gazella }\end{array}$ & Coleoptera & $>770$ & 770 & & Hoechst-Roussel, 1995 \\
\hline
\end{tabular}

\subsection{Resultaten toetsing mengsels van stoffen aan standaard bodemevertebraten}

De voor bodem berekende dan wel rechtstreeks in mest gemeten concentraties van middelen worden vergeleken met de 'indicatieve norm' voor chronische toxiciteit van standaard bodemevertebraten. In deze paragraaf gebeurt dat op een zodanige manier dat rekening wordt gehouden met de gelijktijdige aanwezigheid van meerdere stoffen in grond/mest door de bijdrage van individuele stoffen te sommeren over alle aangetroffen stoffen (combinatietoxiciteit). Hierbij wordt het concept van 'concentratie-additie' gehanteerd, waarbij wordt aangenomen dat elke stof, ongeacht zijn werkingsmechanisme, bijdraagt aan de totale toxiciteit naar rato van zijn aanwezigheid, uitgedrukt als de verhouding tussen concentratie en norm.

\subsubsection{Bestrijdingsmiddelen}

Er zijn in totaal 26 monsters drijfmest of vaste mest geanalyseerd op de aanwezigheid van bestrijdingsmiddelen. Deze monsters waren afkomstig van 22 bedrijven. Op bedrijf 1, 7 en 10 werd geen mest bemonsterd, terwijl op bedrijf 16, 21 en 24 zowel drijf- als vaste mest werd bemonsterd en op bedrijf 20 drijfmest van zowel rundvee als van varkens afzonderlijk bemonsterd werd.

Onderstaande tabel (Tabel 5) geeft een overzicht (per bemonsterde matrix op een bedrijf) hoeveel verschillende bestrijdingsmiddelen in de mest werden aangetroffen en waarvoor een concentratie in de grond is uitgerekend en hoeveel Toxic Units (berekend op basis van de 'indicatieve chronische norm' voor bodemorganismen) aan bestrijdingsmiddelen dit omvatte. Als de Toxic Unit groter is dan 1, betekent dit dat er een risico bestaat.

Er zijn grote verschillen tussen de monsters, zowel qua aantal aangetroffen bestrijdingsmiddelen als wat betreft het aantal Toxic Units en de stoffen die daar in de hoogste mate aan bijdragen.

Het berekende aantal Toxic Units voor bodemorganismen, gesommeerd over alle stoffen, overschrijdt de waarde van 1 eenheid (indicatieve norm voor chronische mengseltoxiciteit) voor 5 van de berekende bodemconcentraties. Op bedrijf 3, 4 en 25 geldt dit voor een drijfmestmonster, terwijl dit op bedrijf 17 en 24 geldt voor een vaste-mestmonster.

In het vaste-mestmonster van bedrijf 24 is er geen enkele individuele stof die een bijdrage aan de 'Toxic Unit' berekening heeft die groter dan 1 is. Hoewel de grootste bijdrage geleverd wordt door epoxiconazole (0.152), dragen andere stoffen dusdanig bij dat er een TU van 1.184 berekend wordt (Tabel 5). Bij bedrijf 3, 4, 17 en 25 is de stof epoxiconazole verantwoordelijk voor een partiële 
toxiciteit van meer dan 1 en is deze stof verantwoordelijk voor het bereiken van een TU groter dan 1. Op bedrijf 25 geldt dit tevens voor de stof Pirimifos-methyl.

Tabel 5 Berekende mengseltoxiciteit van bestrijdingsmiddelen in bodem als gevolg van het uitrijden van mest. Gekleurde cellen betreffen overschrijdingen van de 'indicatieve norm'.

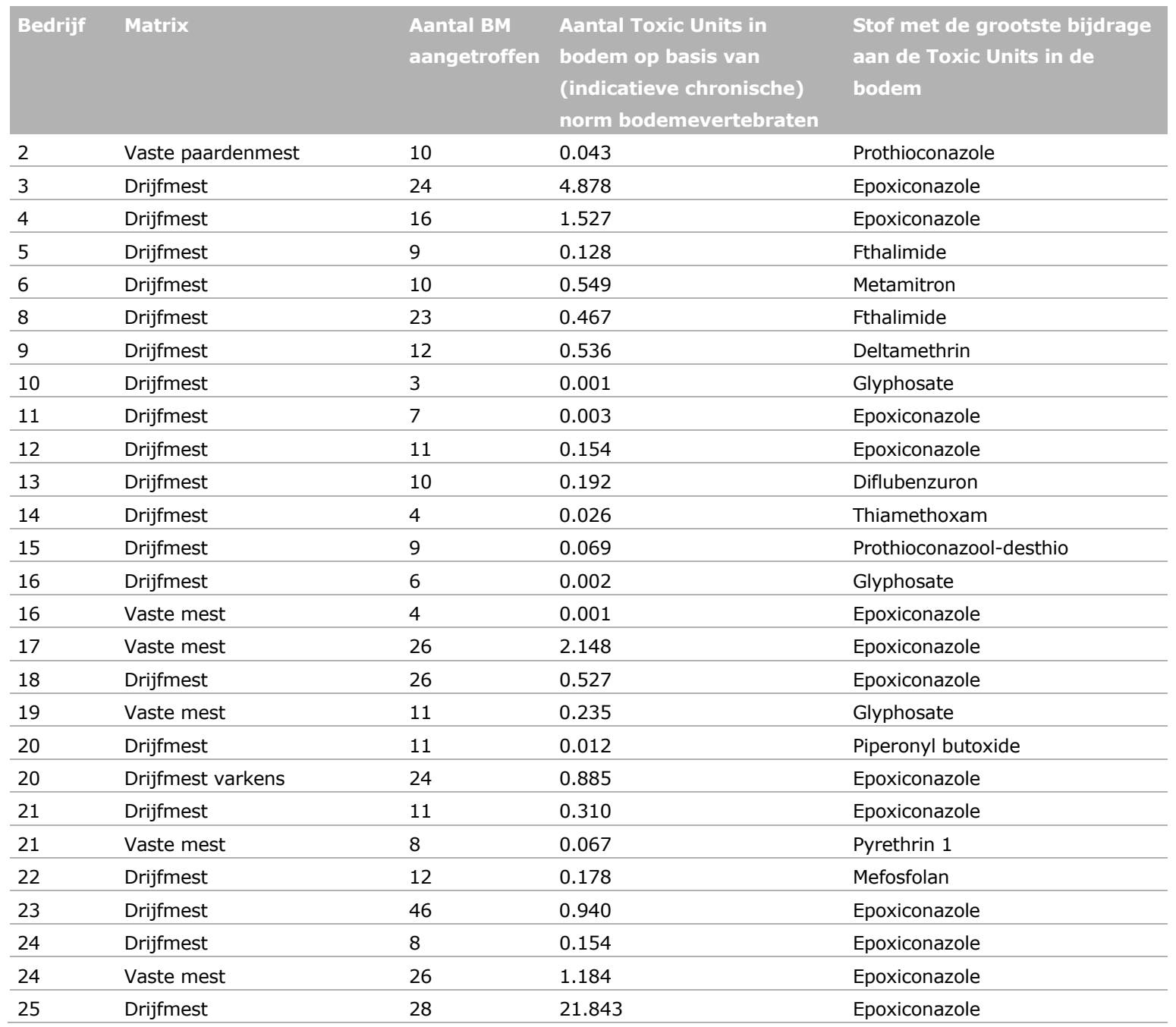

\subsubsection{Veterinaire middelen}

Door het ontbreken van dossiergegevens met betrekking tot de toxiciteit van veterinaire middelen voor standaard bodemevertebraten is toetsing niet mogelijk.

\subsection{Resultaten toetsing mengsels van stoffen aan niet- standaard bodemevertebraten}

De in mest gemeten concentraties van bestrijdingsmiddelen en veterinaire middelen worden omgerekend naar de resulterende concentraties in de bodem en vergeleken met de 'indicatieve norm' op basis van (geschatte) chronische toxiciteit voor standaard bodemevertebraten of chronische toxiciteit voor niet-standaard bodemevertebraten. Daarnaast worden de direct gemeten concentraties vergeleken met de toxiciteitswaarden van typische mest organismen. In deze paragraaf gebeurt dat op een zodanige manier dat rekening wordt gehouden met de gelijktijdige aanwezigheid van meerdere stoffen in mest door de bijdrage van individuele stoffen te sommeren over alle aangetroffen stoffen (combinatietoxiciteit). Hierbij wordt het concept van 'concentratie-additie' gehanteerd, waarbij wordt 
aangenomen dat elke stof, ongeacht zijn werkingsmechanisme, bijdraagt aan de overall toxiciteit naar rato van zijn aanwezigheid uitgedrukt als de verhouding tussen concentratie en norm.

\subsubsection{Bestrijdingsmiddelen}

De enige (niet-standaard) soort waarvoor toxiciteitsgegevens beschikbaar zijn voor meerdere (twee) stoffen, is de spiegelkever Hister spp.; voor alle andere niet-standaard bodemorganismen zijn onvoldoende gegevens beschikbaar om combinatiewerking van stoffen te toetsen. Daar dit een kever is die typisch tot de verse mest zelf aangetrokken is, wordt hier een directe vergelijking met de gemeten concentratie in mest gemaakt.

Zoals reeds bij de analyse van individuele stoffen vermeld, werd op een van de bedrijven cypermethrin en deltamethrin gevonden in vaste mest in gehalten van respectievelijk $0.10 \mu \mathrm{g} / \mathrm{kg}$ vers gewicht en $2.85 \mu \mathrm{g} / \mathrm{kg}$ vers gewicht. De EC50 (overleven) voor Hister spp. van deze stoffen bedraagt respectievelijk 60 en $10 \mu \mathrm{g} / \mathrm{kg}$ mest (Tabel 3). Het 'mengsel' wordt derhalve gedomineerd door de aanwezige concentratie van deltamethrin, dat op dit bedrijf in vaste mest aanwezig is in een concentratie die mogelijk acute effecten in de keversoort Hister spp. zouden kunnen veroorzaken.

\subsubsection{Veterinaire middelen}

Van de veterinaire middelen waarvoor toxiciteitsgegevens voor mestorganismen beschikbaar zijn (doramectine, fenbendazole, ivermectine en moxidectine), zijn de gehalten in vaste mest alle beneden de rapportagegrens. Een uitzondering vormen twee metingen voor ivermectine, die hoger zijn dan de rapportagegrens. Aangezien alleen ivermectine mogelijk is aangetroffen boven de rapportagegrens, is er geen sprake van een 'mengsel' van veterinaire middelen.

\subsection{Samenvatting toetsing aan 'indicatieve norm'}

Voor 975 metingen in drijfmest of vaste mest werd een concentratie in bodem berekend. Hiervan werden er 906 getoetst aan de 'indicatieve norm' voor bodemevertebraten. Voor individuele stoffen was er slechts in vijf gevallen sprake van overschrijding van de 'indicatieve norm' voor bodemevertebraten. Dit betrof de stof epoxiconazool op bedrijf 3, 4, 17 en 25 en de stof Pirimifos-methyl op bedrijf 25.

Op een van de bedrijven is deltamethrin aanwezig in vaste mest in concentraties die $15 \%$ van de acute effectconcentratie (EC50) voor de spiegelkever Hister spp. bedragen, en dus mogelijk enige acute effecten voor deze kever zouden kunnen veroorzaken.

Voor doramectine zijn de gerapporteerde gehalten in vaste mest alle beneden de rapportagegrens van $1 \mu \mathrm{g} / \mathrm{kg}$, terwijl de chronische toxiciteitswaarde op $2.4 \mu \mathrm{g} / \mathrm{kg}$ ligt. De gehalten in vaste mest zijn dus mogelijk slechts weinig lager dan de niveaus waarop chronische effecten zijn te verwachten. Met zekerheid kan hierover echter geen uitspraak worden gedaan, omdat het werkelijke gehalte doramectine onbekend is.

Voor ivermectine zijn voor twee monsters relatief hoge gehalten ( 2 resp. $12 \mu \mathrm{g} / \mathrm{kg}$ ) gerapporteerd, maar is aangegeven dat er sprake was van grote onbetrouwbaarheid in de verkregen resultaten. Interpretatie van deze gehalten in termen van 'mogelijk risico' is daarom niet goed uitvoerbaar. Alle andere gerapporteerde gehalten in vaste mest liggen beneden de rapportagegrens van $1 \mu \mathrm{g} / \mathrm{kg}$, terwijl de gevonden chronische toxiciteitswaarde ook rond dit getal ligt. Hoewel het werkelijke gehalte van ivermectine onbekend is, kan over een daadwerkelijk risico geen uitspraak gedaan worden, maar is dit wel een punt van aandacht.

Van de gerapporteerde mestmonsters zijn er vijf waarvoor het gezamenlijke in de bodem berekende gehalte aan bestrijdingsmiddelen (sommatie van 'Toxic Units' over alle bestrijdingsmiddelen) hoger is dan één Toxic Unit. Op bedrijf 3, 4 en 17 wordt dit alleen door de stof epoxiconazole veroorzaakt, op bedrijf 25 door epoxiconazool en Pirimifos-methyl, terwijl op bedrijf 24 de overschrijding veroorzaakt wordt door een meer evenwichtigere bijdrage van verschillende middelen. 


\section{$5 \quad$ Welke emissieroutes spelen een rol bij de gemeten/berekende concentraties in mest en bodem?}

De toelating van gewasbeschermingsmiddelen en biociden is gereguleerd op het specifieke gebruik van deze stoffen en neemt hiervoor de relevante blootstellingsroutes in ogenschouw. Een potentiële blootstelling van bodemorganismen aan gewasbeschermingsmiddelen wordt geëvalueerd vanuit de hoeveelheid middel die in het gewas toegepast wordt en wat er vervolgens na interceptie (de hoeveelheid middel die afgevangen wordt door het gewas zelf) op de bodem komt. Deze hoeveelheid wordt vergeleken met de toxiciteitswaarde voor de worm (die doorgaans in het laboratorium bepaald is), waarna er al dan niet een risico aanwezig is en toelating wel of niet kan plaatsvinden. Hierbij moet worden opgemerkt dat vanaf 2020 ook de toxiciteitswaarde voor springstaart en bodemmijt (grijs gearceerd in Figuur 2) gebruikt wordt.

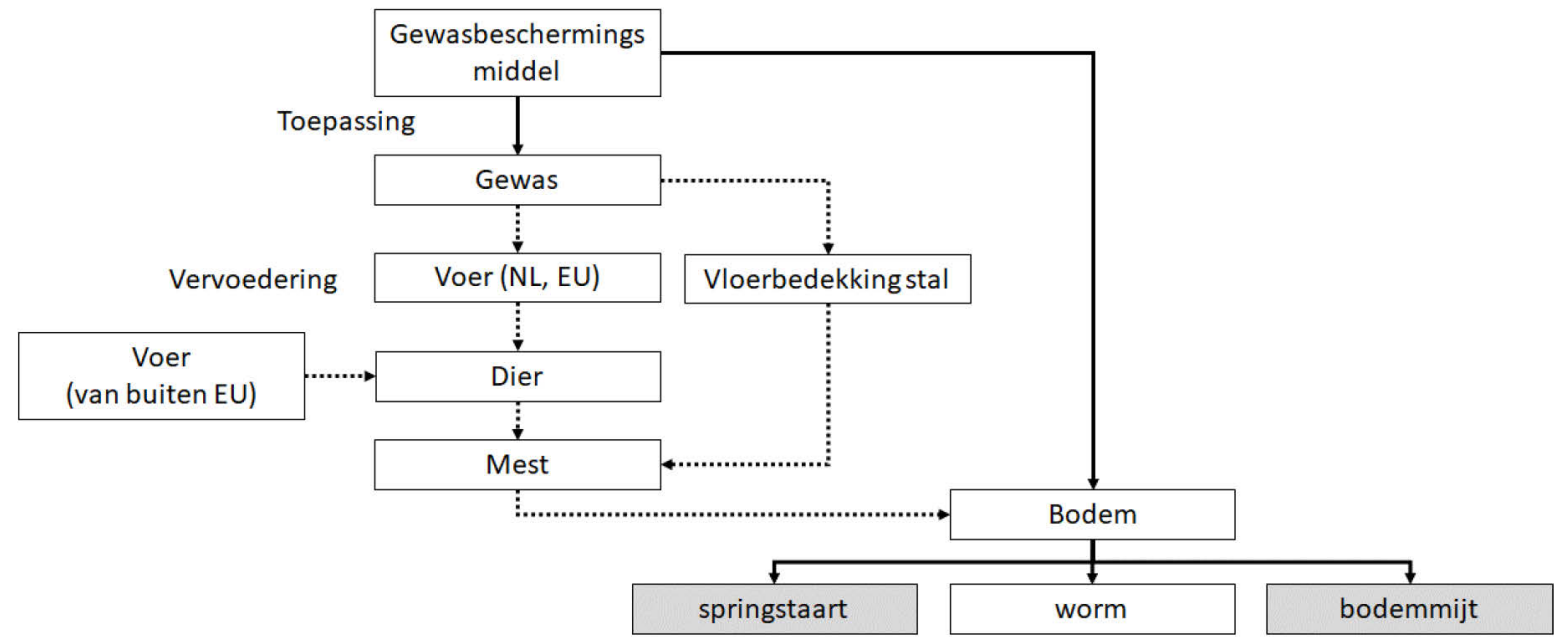

Figuur 2 Schematische weergave van de routes van gewasbeschermingsmiddelen. Routes naar de bodem die deel uitmaken van de beoordeling, zijn weergegeven met een doorgetrokken lijn, additionele routes zijn weergegeven met een stippellijn.

Het rapport van Buijs en Samwel-Mantingh (2019) heeft het voorkomen van gewasbeschermingsmiddelen in mest aangetoond. Deze middelen kunnen in de mest terechtkomen doordat behandelde gewassen vervoederd worden of dieren direct grazen op behandeld grasland.

Omdat er alleen gemeten concentraties gerapporteerd zijn en de volumes en de samenstelling van het gebruikte voer per bedrijf ontbreken, is het niet mogelijk om een massabalans te maken en daardoor inzicht te krijgen in de bijdrage van mengvoer en ruwvoer op de absolute hoeveelheid actieve stof in de mest. De variatie in samenstelling van rundveevoeders en de grote mate van variabiliteit in de oorsprong van grondstoffen gebruikt bij het vervaardigen van deze voeders (zie Figuur 3), zou een verklaring kunnen geven voor het feit dat er een breed scala aan actieve stoffen gevonden is. Gegevens over het voorkomen van actieve stoffen in grondstoffen in diervoeders zijn bekend bij brancheorganisatie SecureFeed, maar zijn helaas niet beschikbaar gesteld voor een verdere duiding van de concentraties aan actieve stoffen in mengvoer. 


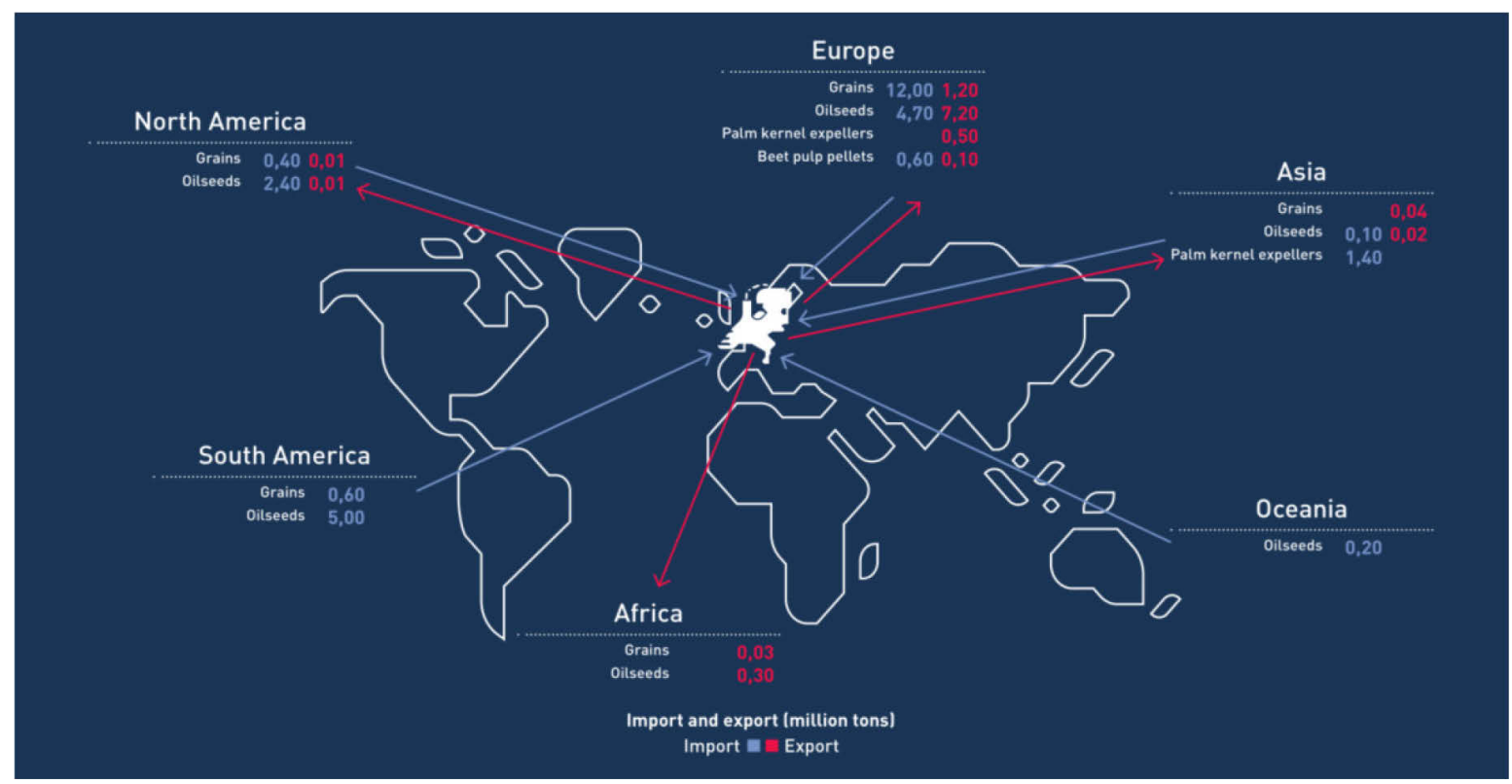

Figuur 3 Import en export van goederen (*miljoen ton) voor gebruik in o.m. diervoeders (Comité van Graanhandelaren, 2019).

Een alternatieve route waarbij middelen in mest terecht kunnen komen, betreft het gebruik van delen van het gewas (bijvoorbeeld halmen van tarwe, zijnde stro) als bodembedekking in de stal. Dit laatste zal dan met name een route voor zogenaamde 'vaste mest' zijn, waarbij de uitwerpselen van dieren vermengd zijn met dit materiaal.

Daar de mest op het land gebracht wordt, is mest derhalve een route waarbij bodemorganismen in potentie blootgesteld kunnen worden aan residuen. Hoewel het huidige toetsingskader rekening houdt met residuen van gewasbeschermingsmiddelen in de bodem, doet het dit alleen vanuit de directe toepassing op het gewas (Figuur 2). Het huidige toetsingskader voorziet niet in de mogelijkheid om een toepassing op een bepaald gewas te relateren aan de uiteindelijke concentratie in de bodem als gevolg van het uitrijden van mest van dieren die dit gewas vervoederd hebben gekregen en ook niet in het uitrijden van behandeld gewas dat wordt gebruikt als stalbodembedekking (Figuur 2).

Biociden worden toegepast voor zowel dierhygiëne (PT3) als plaagbestrijding (PT18) in de stal. Producten uit de PT3-groep omvatten desinfecterende middelen, producten voor mond- en lichaamshygiëne van het dier of middelen met een antimicrobiële werking. Producten uit de PT18groep omvatten middelen die ingezet worden om plaagdieren te bestrijden in de stal.

Middelen met een directe toepassing op landbouwhuisdieren zijn o.a. bedoeld voor desinfectie van uiers en hoeven. Als de dieren in de stal gemolken worden, zal hierbij een route naar de mestopslag plaatsvinden. Residuen van middelen op de vacht/huid van landbouwhuisdieren worden wel meegenomen in de berekening van humane risico's via blootstelling als gevolg van consumptie van bijvoorbeeld melk en vlees. Hiervoor is een maximale residulimiet (MRL) vastgesteld. De huidige toelating voorziet echter niet in een schatting van mogelijke milieurisico's van dergelijke stoffen door uitscheiding via mest (zie stippellijn in Figuur 4). 


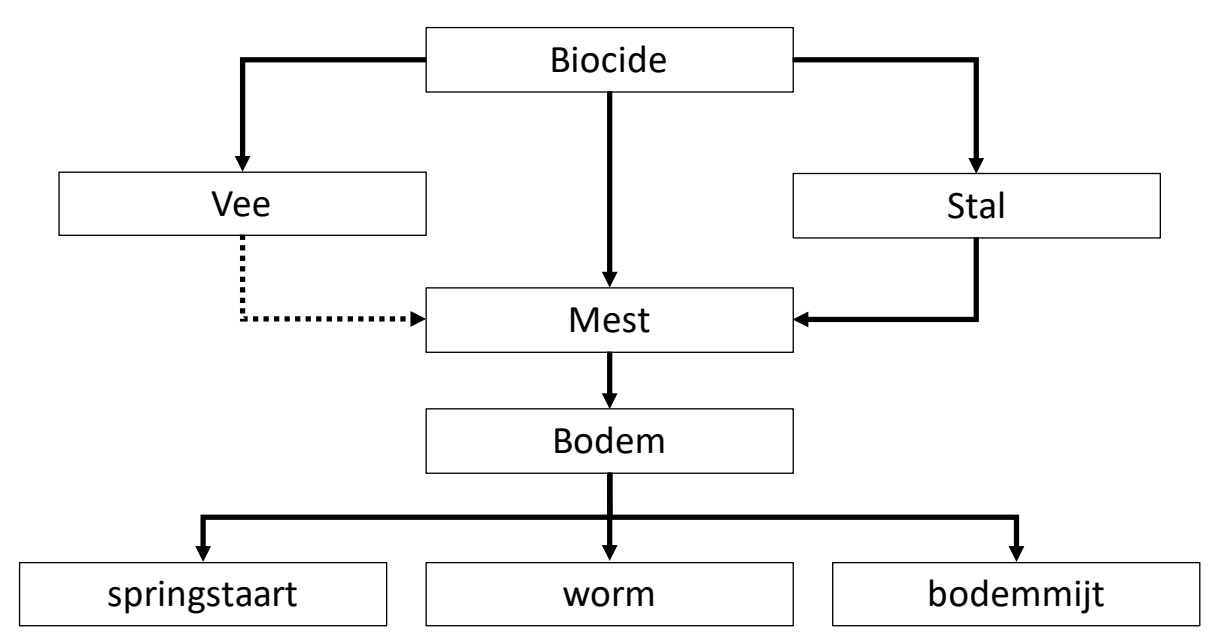

Figuur 4 Schematische weergave van de routes van biociden. Routes die deel uitmaken van de beoordeling, zijn weergegeven met een doorgetrokken lijn, alternatieve routes zijn weergegeven met een stippellijn.

Ook is het mogelijk dat de mest direct met een biocide behandeld wordt. Biociden komen indirect in de mest terecht door bijvoorbeeld de desinfectie van schoeisel van personeel en bij de schoonmaak van de stal en/of mestopslagsysteem zelf. Dit laatste omdat het over het algemeen verboden is in heel Europa om afvalwater dat drijfmest bevat op een openbare (gemeentelijke) riolering te lozen waardoor het vloeibaar mest-houdend afvalwater derhalve naar de drijfmesttank afgevoerd wordt. Het is ook mogelijk dat dit naar een separate afwateropslagtank gaat, maar ook vanuit deze opslag kan dit water weer op het land gebracht worden. De fractie van de biocide die de mest of het mestopslagsysteem bereikt, hangt af van de diersoort en diercategorie (d.w.z. het type huisvesting en drijfmestsysteem), de manier van toepassing en de fysische eigenschappen van de biocide in kwestie. Deze emissieroutes worden in de toelating meegenomen (zie Figuur 4). De hieruit voortkomende blootstellingsconcentratie in de bodem wordt getoetst tegen de norm afgeleid van toxiciteitswaarden voor regenwormen, springstaarten, bodemmijten, terrestrische planten en microbiële activiteit.

Omdat er alleen enkele incidentele toxiciteitsgetallen van diergeneesmiddelen voor bodemevertebraten beschikbaar waren en hierdoor geen goede inschatting van het risico van deze stoffen kon worden gemaakt, is in dit rapport verder geen aandacht besteed aan mogelijke emissieroutes. Daar deze middelen alleen voor behandeling van het dier gebruikt worden, is dit ook een redelijk overzichtelijke route. 


\section{Discussie}

\subsection{Algemeen}

Voor 975 metingen in drijfmest of vaste mest werd een concentratie in bodem berekend. Hiervan konden er 906 getoetst worden aan de 'indicatieve norm' voor bodemevertebraten. In het algemeen zijn de berekende concentraties aan bestrijdingsmiddelen ver beneden concentraties waarbij effecten op bodemevertebraten kunnen worden verwacht. Voor individuele stoffen was er slechts in vijf gevallen sprake van overschrijding van de 'indicatieve norm' voor bodemevertebraten. Dit betrof de stof epoxiconazool op bedrijf 3, 4, 17 en 25 en de stof Pirimifos-methyl op bedrijf 25.

Op een van de bedrijven is deltamethrin aanwezig in vaste mest in concentraties die weliswaar onder de acute effectconcentratie (EC50) voor de spiegelkever Hister spp. liggen, maar mogelijk toch enige acute effecten in deze in mest levende kever zouden kunnen veroorzaken.

Omdat de werkelijke gehalten voor de gerapporteerde veterinaire middelen onbekend zijn (want: gerapporteerd als beneden de rapportagegrens of gekenmerkt als weinig betrouwbaar), kan voor doramectine en ivermectine niet met zekerheid worden gezegd in hoeverre de aanwezigheid van deze stoffen tot effecten op bodemleven zal leiden. Voor de overige gerapporteerde veterinaire middelen ontbreken toxiciteitsgegevens om een uitspraak over mogelijke risico's te kunnen doen. Hierbij moet opgemerkt worden dat het bij deze groep stoffen soms voorkomt dat de rapportagegrens van de chemische analyse en de beschikbare effectconcentraties heel dicht bij elkaar liggen. In theorie zou dit kunnen leiden tot een situatie waarbij de stof in concentraties aanwezig is die weliswaar net niet gerapporteerd kunnen worden, maar net wel tot effect leiden. Of hier daadwerkelijk sprake is van een risico, kan op basis van de beschikbare gegevens niet aangetoond worden.

De voor de analyse beschikbare gegevens (in mest gemeten concentraties van bestrijdingsmiddelen en veterinaire middelen) weerspiegelen een momentopname, omdat er sprake is van eenmalige bemonstering. Er is slechts voor drie middelen geconstateerd dat er in zes gevallen sprake is van een mogelijk risico voor bodemevertebraten.

Dit betreft de aanwezigheid van epoxiconazool en Pirimifos-methyl in drijfmest van een enkel bedrijf, en de aanwezigheid van deltamethrin in vaste mest die in onverdunde vorm aanwezig is in concentraties die mogelijk acute effecten zouden kunnen veroorzaken in een keversoort die in mest leeft.

Wat betreft epoxiconazool wordt deze waarneming waarschijnlijk veroorzaakt door de afleiding van de indicatieve norm, waarbij een veiligheidsfactor is gebruikt van 100. Deze veiligheidsfactor is verondersteld, omdat er maar één chronische toxiciteitswaarde beschikbaar was voor de worm in plaats van de gebruikelijke drie. Deze waarde van 0.08 ug a.s./kg droge grond (EFSA, 2008) resulteert derhalve, gebruikmakend van een factor 100, in een indicatieve norm van 0.0008 ug a.s./kg. Echter de stof is tijdens de hernieuwingsaanvraag voor toelating uit het beoordelingsproces teruggetrokken. Interessant is verder dat in de hernieuwingsaanvraag voor toelating een nieuwe wormenstudie staat vermeld en dat hierin een chronische toxiciteitswaarde van $3.24 \mathrm{mg}$ a.s. $/ \mathrm{kg}$ droge grond wordt vermeld. Het gebruik van deze waarde voor het afleiden van de indicatieve norm resulteert in $0.0324 \mathrm{mg}$ a.s./ $\mathrm{kg}$ droge grond, waarmee alle overschrijdingen van epoxiconazole komen te vervallen. Omdat de aanvraag tot hernieuwing is ingetrokken, is niet duidelijk hoe de twee studies zich tot elkaar verhouden en of het oude getal inderdaad kan worden vervangen door de nieuwe waarde. Omdat de stof zijn toelating kwijtraakt, is hier geen verdere interventie vanuit het beleid voor nodig.

Ook voor Pirimifos-methyl geldt dat er maar voor één soort een chronische toxiciteitswaarde beschikbaar is. Hierdoor wordt er in dit rapport een conservatieve factor 100 gebruikt om de 
indicatieve norm af te leiden. Mocht er voor een tweede soort een chronische toxiciteitswaarde beschikbaar komen en is deze groter dan de huidige (of ten minste in dezelfde ordegrootte), dan wordt de indicatieve norm afgeleid van gevoeligste waarde, gebruikmakend van een factor 10, waarmee ook deze overschrijding komt te vervallen. Omdat sinds dit jaar ook het aanleveren van chronische data voor springstaarten en bodemmijten verplicht gesteld is, worden dergelijke lacunes in de beschikbare data vanzelf opgevuld tijdens de aanvragen voor hernieuwde toelating.

\subsection{Tijdsaspect}

De door Buijs et al. (2019) gerapporteerde concentraties in mest en andere matrices geven de situatie op het moment van bemonstering weer. Onduidelijk is in hoeverre deze momentopname representatief is voor de situatie op andere momenten.

Het lijkt aannemelijk dat de gerapporteerde gehalten in stalmest de gehalten in verse vlaaien onderschatten. Afbraak van de stoffen tussen het tijdstip van uitscheiding en het moment van bemonstering/meting kan hebben bijgedragen aan een verlaging van het gehalte. Daarnaast wordt ook de afbraak die mogelijk optreedt tussen het tijdstip van monstername en het moment van uitrijden/inwerken verwaarloosd. Ook dit leidt mogelijk tussen een overschatting van het werkelijk optredende risico.

Om een beter beeld te krijgen van de maximale en gemiddelde concentraties van bestrijdingsmiddelen in mest zou het nodig zijn om verse mest te bemonsteren en opgeslagen mest in de tijd te volgen.

\subsection{Simultane aanwezigheid van meerdere stoffen: combinatiewerking}

In de beoordeling van de risico's die mogelijk optreden als gevolg van de gelijktijdige aanwezigheid van meerdere stoffen (mengsel- of combinatietoxiciteit) is aangenomen dat de concentratie van alle stoffen, mits genormeerd naar de (geschatte) chronische toxiciteit van de stof en derhalve uitgedrukt als chronische 'Toxic Units', zal bijdragen aan het totale risico naar rato van zijn aanwezigheid/concentratie. Dit betekent dat sommatie van Toxic Units plaatsvindt over stoffen met een verschillend werkingsmechanisme. Dit is een pragmatische keuze, omdat 1) werkingsmechanismen voor niet-doelwit soorten veelal onbekend zijn en dus groepering naar werkingsmechanismen niet goed mogelijk is, en 2) in de praktijk veelal blijkt dat het gebruik van concentratie-additie over alle werkingsmechanismen leidt tot een 'worstcaseschatting' van de te verwachten toxiciteit (Deneer et al., 2000).

Bovendien is de sommatie van Toxic Units uitgevoerd over een 'indicatieve chronische norm' voor bodemleven die niet voor elke stof is gebaseerd op hetzelfde organisme (welk organisme het gevoeligst is voor een stof zal per stof verschillen). Daarom is de hier uitgevoerde sommatie een overschatting van het aantal Toxic Units dat voor iedere afzonderlijke soort zou zijn berekend (als de benodigde gegevens beschikbaar zouden zijn geweest voor iedere soort), zodat ook hier sprake is van een worstcaseschatting van de te verwachten toxiciteit.

Men dient echter te bedenken dat het eventueel optreden van interacties in de werking van stoffen in de vorm van antagonisme (verzwakking van het effect) of synergisme (versterking van het effect) kan leiden tot onjuistheden in de geschatte risico's. Er is relatief weinig informatie omtrent het optreden van dergelijke interacties in de bodem. Voor waterorganismen zijn meer studies naar combinatiewerking van stoffen met verschillend werkingsmechanismen uitgevoerd, waarbij het optreden van interacties relatief zeldzaam is gebleken (Deneer et al., 2000; Cedergreen, 2014).

Voor de situaties waarin combinatiewerking zoals berekend met concentratie-additie een indicatie geeft dat er mogelijk sprake is van risico's voor bodemleven wordt het 'mengsel' zodanig gedomineerd door de aanwezigheid van één of twee stoffen dat de beoordeling van de combinatiewerking weinig toevoegt ten opzichte van de beoordeling op basis van individuele stoffen. 
Een mogelijke manier om aannames omtrent het al dan niet optreden van synergisme of antagonisme tussen stoffen te vermijden, is het inzetten van bio-assays, waarbij eventuele interacties tussen stoffen tot uiting komen in het resulterende effect. Nadeel van het gebruik van bio-assays is het ontbreken van informatie omtrent de oorzaak van eventueel geconstateerde effecten. Bio-assays dienen, als men causaliteit aan wil tonen, dan ook altijd gecombineerd te worden met de resultaten van chemische analyses en met toxiciteitsgegevens voor de soorten waarvoor effecten zijn geconstateerd.

\subsection{Beoordeling risico's}

Voor 98 van de 108 in mest aangetroffen bestrijdingsmiddelen waren voldoende toxiciteitsgegevens beschikbaar om een '(indicatieve) norm' voor bodemevertebraten af te leiden. Voor geen enkele van de gerapporteerde veterinaire middelen werden toxiciteitsgegevens voor standaard bodemevertebraten gevonden in de geraadpleegde toelatingsdossiers.

Voor niet-standaard bodemevertebraten werden voor drie van de gerapporteerde bestrijdingsmiddelen (cyfluthrin, cypermethrin en deltamethrin) en voor vier van de gerapporteerde veterinaire middelen (doramectine, fenbendazole, ivermectine en moxidectine) toxiciteitsgegevens voor een of meer soorten gevonden.

Op een van de bedrijven was deltamethrin aanwezig in vaste mest in een concentratie die in de buurt kwam van de acute effectconcentratie (EC50) voor de spiegelkever Hister spp. en die mogelijk geringe acute effecten in deze kever zou kunnen veroorzaken.

Voor doramectine zijn de gerapporteerde gehalten alle beneden de rapportagegrens $(1 \mu \mathrm{g} / \mathrm{kg})$, wat slechts weinig lager is dan de chronische toxiciteitswaarde van $2.4 \mu \mathrm{g} / \mathrm{kg}$ voor de kever Onthophagus gazella. Het is onduidelijk of doramectine effecten zou kunnen veroorzaken, omdat de werkelijke gehalten onbekend zijn. Voor ivermectine zijn voor twee mestmonsters relatief hoge, maar onbetrouwbare gehalten gerapporteerd. Alle overige gehalten van ivermectine waren beneden de rapportagegrens $(1 \mu \mathrm{g} / \mathrm{kg})$, terwijl de chronische toxiciteitswaarde $0.84 \mu \mathrm{g} / \mathrm{kg}$ voor de vlieg Scatophaga stercoraria bedraagt. Het is onduidelijk of ivermectine effecten zou kunnen veroorzaken, omdat de werkelijke gehalten onbekend zijn.

Voor de vijf situaties waarin combinatiewerking zoals berekend met concentratie-additie een indicatie geeft dat er mogelijk sprake is van risico's voor bodemevertebraten (gesommeerde concentratie $>1$ Toxic Unit voor chronische toxiciteit), wordt het 'mengsel' zodanig gedomineerd door de aanwezigheid van één of twee stoffen dat de beoordeling van de combinatiewerking weinig toevoegt ten opzichte van de beoordeling op basis van individuele stoffen.

\subsection{Emissieroutes}

De gehalten van de gerapporteerde middelen in vaste mest en drijfmest kunnen uit verschillende routes afkomstig zijn. Daar er op verschillende bedrijven veel meer en totaal andere middelen gerapporteerd zijn dan logischerwijs op een veeteeltbedrijf verwacht zou worden, geeft aan dat in ieder geval voor gewasbeschermingsmiddelen externe routes van belang zijn. Ruwvoer en mengvoer zijn hierbij mogelijke relevante routes. Echter gezien de weinige overschrijdingen van de indicatieve norm, lijken de hoeveelheden die hiermee gemoeid zijn vanuit het perspectief van de risicobeoordeling niet meteen een aanleiding te vormen voor nader onderzoek.

Daarentegen komen biociden niet via het voer in de mest en hier spelen de routes vanuit dier- en bedrijfsmanagement een belangrijke rol. Ook hier geldt echter dat er voor deze stoffen geen overschrijdingen worden gevonden en dat de hoeveelheden die hiermee gemoeid zijn vanuit het perspectief van de risicobeoordeling niet meteen een aanleiding vormen voor nader onderzoek. Hierbij moet wel de kanttekening gemaakt worden dat het voorkomen van het anti-insectenmiddel DEET in de monsters opvallend is. DEET kent alleen een officiële toepassing voor humaan gebruik en een toepassing voor landbouwhuisdieren kon niet gevonden worden. 
Door Buijs en Samwel-Mantingh (2019) zijn voor 26 mestmonsters, verzameld op 22 verschillende bedrijven, analyseresultaten voor 108 bestrijdingsmiddelen en 21 veterinaire (antiparasitaire) middelen gerapporteerd. De huidige verdiepende analyse heeft getracht te achterhalen hoe betrouwbaar de in het rapport van Buijs en Samwel-Mantingh (2019) gemeten gehalten van middelen zijn, in welke mate gerapporteerde concentraties van de afzonderlijke stoffen individueel en/of in combinatie een risico voor evertebraten in mest en bodem vormen en welke emissieroutes een rol spelen bij de gemeten/berekende concentraties in mest en bodem.

\section{Betrouwbaarheid analyses}

Door de onvoldoende gedetailleerde beschrijving van de gebruikte analysemethodieken - met name van de uitgevoerde validaties - voor bestrijdingsmiddelen (Eurofins) en veterinaire middelen (RIKILT) is het niet mogelijk de betrouwbaarheid van de analyses te beoordelen. Een deel van de door Eurofins gerapporteerde getallen is beneden de opgegeven rapportagegrens en lijkt daarmee hoe dan ook onbetrouwbaar. Daar de toelating van middelen een streng proces is dat gebaseerd is op zeer gedetailleerd gedocumenteerde dossiers, staat dit in aanzienlijk contrast met de beschikbare beschrijving in het rapport van Buijs en Samwel-Mantingh (2019). Op basis van de kwaliteit van deze gegevens is het niet waarschijnlijk dat er een interventie vanuit het beleid kan plaatsvinden.

\section{Mogelijke risico's voor evertebraten}

Desalniettemin betekent dit niet dat er geen signalerende functie van het originele rapport uitgaat en daarom is onderzocht in welke mate gerapporteerde concentraties van de afzonderlijke stoffen individueel en/of in combinatie een risico voor evertebraten in mest en bodem kunnen vormen. Daarbij is gebruikgemaakt van zowel standaard OECD-testen en niet-standaard testen. Van de 975 metingen van bestrijdingsmiddelen in drijf- of vaste mest konden er 906 worden getoetst aan een 'indicatieve norm' voor bodemevertebraten. Overschrijding van de 'indicatieve norm' door individuele stoffen vond slechts in 5 van de 906 getoetste mestmonsters en de daaruit afgeleide gehalten in bodem plaats en werd veroorzaakt door de stoffen epoxiconazool ( 5 keer) en pirimifos-methyl ( 1 keer, in eenzelfde monster waar epoxiconazole ook al overschrijdend was).

Op een van de bedrijven werd deltamethrin aangetroffen in vaste mest in een concentratie die weliswaar onder de acute effectconcentratie voor bodemevertebraten lag, maar daar dichtbij genoeg in de buurt kwam om mogelijke enkele effecten in de spiegelkever Hister spp. te veroorzaken.

Er zijn slechts drie actieve stoffen waarvoor in een gelimiteerd aantal gevallen is geconstateerd dat er mogelijk sprake is van risico voor bodemevertebraten. Dit betreft de aanwezigheid van epoxiconazool (vijf monsters) en pirimifos-methyl (één monster) in drijfmest en de aanwezigheid van deltamethrin in vaste mest (één monster) die in onverdunde vorm mogelijk enige acute effecten in een keversoort zouden kunnen veroorzaken.

Hierbij moet worden opgemerkt dat de overschrijdingen van epoxiconazool en pirimifos-methyl mogelijk veroorzaakt worden door het feit dat er maar één chronische toxiciteitswaarde beschikbaar is, wat door de in dit rapport gevolgde aanpak tot een conservatieve norm leidt. In de reguliere toelatingsprocedure, waarbij andere extrapolatiefactoren gebruikt worden, zou pirimifos-methyl niet tot een overschrijding leiden. Verder is de chronische NOECworm voor pirimifos-methyl $(0.02 \mathrm{mg} / \mathrm{kg})$ gemeten op een eindpunt (verstoring flux over membranen) dat niet gangbaar is als eindpunt in de risicobeoordeling. Door het gebrek aan reguliere toxiciteitswaarden is dit toch gebruikt als conservatieve schatting van de toxiciteit en verdiende dit de voorkeur boven een schatting van de toxiciteit op basis van een MTRwater, welke doorgaans zeer conservatief uitvalt (zie Bijlage 4).

Een meer recente studie in het zogenaamde Renewal Assessment Report (RAR; zoals gerapporteerd in de Pesticide Properties DataBase) naar de chronische toxiciteit van epoxiconazool op wormen 
resulteerde in een hogere NOEC-waarde die niet tot overschrijding van de indicatieve norm leidt. Het is hierbij van belang te weten dat de oude waarde de hoogst geteste concentratie van de stof betrof. Hier werd geen effect op wormen waargenomen, waardoor dit daardoor de NOEC werd. De nieuwe studie heeft een hogere reeks concentraties getest, waarbij wederom de hoogste concentratie weer geen effect op wormen gaf. Dit geeft aan dat er geen risico van epoxiconazool aanwezig was. Dat deze nieuwe getallen alleen in de RAR gevonden kunnen worden, komt doordat de aanvraag voor een hernieuwde goedkeuring voor deze stof is teruggetrokken en EFSA hier geen besluit over heeft hoeven nemen.

Aannemende dat de gerapporteerde analyse resultaten kloppen, is het niet aannemelijk dat de gemeten stofconcentraties per stof leiden tot minder evertebraten in de bodem, en dus tot minder voedsel voor weidevogels.

Voor de stoffen cafeïne, DEET, etoxyquin, fenylfenol-2, hexazinon en picaridin waren geen toxiciteitsgegevens beschikbaar, waardoor hier geen uitspraak over een mogelijk risico gedaan kan worden.

De beoordeling van de mengseltoxiciteit resulteerde in zes overschrijdingen van de 'indicatieve norm', waarbij vijf resulteerden in de eerdergenoemde overschrijdingen van individuele stoffen en één nieuw geval werd gevonden (vaste mest bedrijf 24), waarbij de bijdrage van de individuele stoffen samen tot een overschrijding leidde. De analyse van blootstelling aan een combinatie van gemeten stoffen geeft geen aanleiding om de eerdere conclusie over de impact van individuele stoffen bij te stellen.

Doordat de gerapporteerde gehalten van veterinaire middelen alle beneden de rapportagegrens of onbetrouwbaar waren, kan over vrijwel alle veterinaire middelen geen uitspraak met betrekking tot risico's voor bodemleven worden gedaan. Van doramectine en voor ivermectine kan niet met zekerheid worden gezegd in hoeverre hun aanwezigheid tot effecten op bodemevertebraten zou kunnen leiden en daarmee blijft dit een punt van aandacht.

\section{Emissieroutes}

De gehalten van de gerapporteerde middelen in vaste mest en drijfmest kunnen uit verschillende routes afkomstig zijn. Dat er op verschillende bedrijven veel meer en andere middelen gerapporteerd zijn dan op basis van de reguliere activiteiten op een veeteeltbedrijf verwacht worden, geeft aan dat in ieder geval voor gewasbeschermingsmiddelen externe routes van buiten het bedrijf van belang zijn. Ruwvoer en mengvoer zijn hierbij mogelijke relevante routes. Echter, gezien de weinige overschrijdingen van de indicatieve norm, lijken de hoeveelheden die hiermee gemoeid zijn vanuit het perspectief van de risicobeoordeling niet meteen een aanleiding te vormen voor nader onderzoek.

Daarentegen komen biociden niet via het voer in de mest en spelen hier de routes vanuit dier- en bedrijfsmanagement een belangrijke rol. Ook hier geldt echter dat er voor deze stoffen geen overschrijdingen worden gevonden en dat de hoeveelheden die hiermee gemoeid zijn vanuit het perspectief van de risicobeoordeling niet meteen een aanleiding vormen voor nader onderzoek. Hierbij moet wel de kanttekening gemaakt worden dat het voorkomen van de anti-insectenmiddelen DEET en picaridin in de monsters opvallend is. Deze kennen alleen een officiële toepassing voor humaan gebruik en hierdoor is in de toelating geen milieurisico verondersteld. Het feit dat deze stoffen in mest gedetecteerd zijn, blijkt dat deze aanname aan herziening toe is.

Hoewel er geen directe aanleiding is om op basis van de gegevens uit het rapport van Buijs en Samwel-Mantingh te concluderen dat de genoemde 'blinde vlek' ten aanzien van blootstellingsroutes leidt tot een afname van de evertebraten, adviseren wij om de in dit rapport benoemde onduidelijkheden voor met name veterinaire middelen en middelen die voorheen werden verondersteld geen route naar het milieu te hebben, via wetenschappelijke studies te onderbouwen. 


\section{Literatuur}

Blanckenhorn, W. U., N. Puniamoorthy, M. A. Schafer, A. Scheffczyk, and J. Rombke (2013). Standardized laboratory tests with 21 species of temperate and tropical sepsid flies confirm their suitability as bioassays of pharmaceutical residues (ivermectin) in cattle dung. Ecotox. Environ. Saf. 89, $21-28$.

Boxall, A.B.A., L.A. Fogg, P.A. Blackwell, P. Kay, E.J. Pemberton, A. Croxford (2004). Veterinary medicines in the environment. Rev. Environ. Contam. Toxicol. 180, 1 - 91.

Buijs, J., M. Samwel-Mantingh (2019). Een onderzoek naar mogelijke relaties tussen de afname van weidevogels en de aanwezigheid van gewasbeschermingsmiddelen op veehouderijbedrijven. Buijs Agro-Services, Bennekom, April 2019.

Brock, Th., J. Lahr, D. Melman, T. Visser, L. Wipfler (2019). Duiding van het rapport 'Een onderzoek naar de mogelijke relaties tussen de afname van weidevogels en de aanwezigheid van bestrijdingsmiddelen op veehouderijen' door Jelmer Buijs en Margriet Samwel-Mantingh. Wageningen Environmental Research, 19 april 2019.

Cedergreen, N. (2014). Quantifying synergy: A systematic review of mixture toxicity studies within environmental toxicology. PLoS ONE 9 (5), e96580.

Ctgb (2019). Appreciatie van het rapport "Een onderzoek naar mogelijke relaties tussen de afname van weidevogels en de aanwezigheid van gewasbeschermingsmiddelen op veehouderijbedrijven (Buijs, J en M. Samwel-Mantingh (2019)) door het Ctgb."

Deneer, J.W. (2000). Toxicity of mixtures of pesticides in aquatic systems. Pest Man Sci 56, $516-$ 520.

ECHA (2017a). Chapter R.7c: Endpoint specific guidance. Guidance on Information Requirements and Chemical Safety Assessment. Helsinki: 272.

ECHA (2017b). European Chemicals Agency, Guidance on Biocidal Products Regulation Volume IV, Environment Parts B + C, Version 2.0, October 2017. (https://echa.europa.eu/documents/10162/23036412/bpr_guidance_ra_vol_iv_part_bc_en.pdf/e2622aea-0b93-493f-85a3-f9cb42be16ae).

Fort Dodge (1997). Animal Health, Environmental Assessment - CYDECTIN moxidectin 0.5\% Pour-On for Cattle, Z154314; pp. 1-32.

Hempel, H., A. Scheffczyk, H.-J. Schallnaß, J.-P. Lumaret, M. Al-vinerie, J. Römbke (2006). Toxicity of four veterinary parasiticides on larvae of the dung beetle Aphodius constans in the laboratory. Environ. Toxicol. Chem. 25, 3155 - 3163.

Hoechst-Roussel Ag-Vet Co. (1995) Environmental assessment: febendazole suspension 10\% in dairy cattle of breeding age. Report NADA 128-620. Hoechst-Roussel Ag-Vet Co., Somerville.

ISO 11268-1 (2012) Soil quality - Effects of pollutants on earthworms - Part 1: Determination of acute toxicity to Eisenia fetida/Eisenia andrei.

IOBC (2000a) IOBC/WPRS Guideline (2000): Rove beetle - Aleochara bilineata (http://www.biotecnologiebt.it/en/iobc-wprs-guideline-aleochara-bilineata.php) 
IOBC (2000b) IOBC/WPRS Guideline (2000): Carabid beetle - Poecilus cupreus

(http://www.biotecnologiebt.it/en/iobc-wprs-guideline-poecilus-cupreus.php)

KEMI (2017). Kemikalienspektionen, Swedish Chemicals Agency, Practical guidance on how to access information from the EU pesticide registration process. Version 05.1, 2017-10-02.

Kövecses, J., D.J. Marcogliese (2005). Avermectins: Potential Environ-mental Risks and Impacts on Freshwater Ecosystems in Quebec. Scientific and Technical Report ST-233E. Environment Canada Quebec Region Environmental Conservation St. Lawrence Centre; pp. 1 - 72.

Lahr, J. (2004). Ecologische risico's van diergeneesmiddelengebruik. Een oriëntatie op het terrestrische milieu. Alterra rapport 976, Alterra, Wageningen.

Lahr, J. (2017), N. Bondt, T. de Koeijer, L. Wipfler, B. Berendsen, P. Hoeksma, L. van Overbeek, D. Mevius. A step towards the environmental prioritisation of veterinary medicines from animal manure. Water matters (H2O) 2017 (2).

Lumaret, J.-P., F. Errouissi, K. Floate, J. Römbke, K. Wardhaugh (2012). A review on the toxicity and non-target effects of macrocyclic lactones in terrestrial and aquatic environments. Curr. Pharmac. Biotechnol. 13, $1004-1060$.

Mensink, B.J.W.G. (2008). Environmental risk limits for pirimiphos-methyl. RIVM Letter report 601716011/2008. RIVM.

OECD 220 (2016). Test No. 220: Enchytraeid Reproduction Test.

OECD 222 (2016). Test No. 222: Earthworm Reproduction Test (Eisenia fetida/Eisenia andrei).

OECD 226 (2016). Test No. 226: Predatory mite (Hypoaspis (Geolaelaps) aculeifer) reproduction test in soil.

OECD 232 (2016). Test No. 232: Collembolan Reproduction Test in Soil.

Oste, L., R. Keijzers, V. Mastalerz (2010). Afleiding van het ecotoxicologische deel voor 28 ad hoc MTR's voor 2009. Deltares rapport 1203121-001, Deltares.

Pfizer Inc. (1996). Finding of no significant impact: Dectomax (doramectin) injectable solution for use in swine. NADA 141-061 C0013. Pfizer: Groton.

Reijneveld, J.A., J. van Wensem, O. Oenema (2009). Soil organic carbon contents of agricultural land in the Netherlands between 1984 and 2004. Geoderma 152, $231-238$.

Römbke, J., H. Hempel, A. Scheffczyk, H. Schallnass, M. Alvinerie, J.P. Lumaret (2007). Environmental risk assessment of veterinary pharmaceuticals: development of a standard laboratory test with the dung beetle Aphodius constants. Chemosphere, 70, $57-64$.

Römbke, J., K.D. Floate, R. Jochmann, M.A. Schaefer, N. Puniamoorthy, S. Knaebe, J. Lehmhus, B. Rosenkranz, A. Scheffczyk, T. Schmidt, A. Sharples, W.U. Blanckenhorn (2009). Lethal and sublethal toxic effects of a test.chemical (ivermectin) on the yellow dung fly (Scathophaga stercoraria) based on a standardized international ring test. Environ. Toxicol. Chem. 28, $2117-2124$.

Römbke, J., K. Barrett, W.U. Blanckenhorn, T. Hargreaves, N. Kadiri, S. Knäbe, J. Lehmhus, J.-P. Lumaret, B. Rosenkranz, A. Scheffczyk, T. Sekine (2010). Results of an international ring test with the dung fly Musca autumnalis in support of a new OECD test guideline. Sci. Tot. Environ. $408,4102-4106$. 
Rijkswaterstaat (2008). Afleiding van 41 ad hoc MTR's 2007. Waterdienst rapport 2008.007. Mei 2008.

Vale, G.A., I. F. Grant, C. F. Dewhurst, and D. Aigreau (2004). Biological and chemical assays of pyrethroids in cattle dung. Bulletin of Entomological Research 94, $273-282$.

Weltje, L., L. Posthuma, F.C. Mogo, E.M. Dirven - van Breemen, R.P.M. van Veen (1995). Toxische effecten van combinaties van cadmium, zink en koper op terrestrische oligochaeten in relatie tot bodemchemische interacties. RIVM-rapport 719102043, Bilthoven.

Zorge, J.A. van, J.H. van Wijnen, R.M.C. Theelen, K. Olie, M. van den Berg (1989). Assessment of the toxicity of mixtures of halogenated dibenzo-p-dioxins and dibenzofurans by use of equivalency factors (TEF). Chemosphere 19, $1881-1895$. 


\title{
Bijlage 1 Toelichting op verzamelen toxiciteitswaarden bestrijdingsmiddelen
}

\begin{abstract}
Standaard bodemevertebraten
Voor enkele stofnamen was in eerste instantie niet goed duidelijk welke stoffen bedoeld werden, omdat voor de betreffende naam in de meetgegevens geen toelatingsgegevens werden gevonden. Het betreft hierbij 'DDAC' waarvoor de EU/EFSA toelatingsgegevens van didecyldimethylammoniumchloride zijn gebruikt, en BAC-12 en BAC-14 (die ook bekend staan onder de afkorting ADBAC). Voor deze laatste quaternaire ammoniumverbindingen, die ook als benzalkoniumchloriden worden aangeduid, zijn alleen toelatingsgegevens met betrekking tot toxiciteit voor wormen en niet voor arthropoden gevonden (volgens de ECHA is de afbreekbaarheid van deze stof zo goed dat geen langetermijnblootstelling van terrestrische arthropoden wordt verwacht en dat, in het onwaarschijnlijke geval dit toch gebeurt, het toxicologische profiel van de stof geen reden tot zorg geeft).
\end{abstract}

Volgens een persoonlijke mededeling van dhr. J. Buijs gaat het bij de als 'difenyl' aangeduide stof om de stof met cas-nummer 92-52-4 en betreft het hier dus bifenyl; om deze reden zijn voor 'difenyl' gegevens van bifenyl gebruikt.

Cinerin 1, Jasmolin 1 en Pyrethrin 1 (evenals Cinerin 2, Jasmolin 2 en Pyrethrin 2) vormen onderdelen van pyrethrines. Voor deze afzonderlijke stoffen werden geen EU/EFSA-toelatingsgegevens gevonden, wel voor de 'pyrethrins' als stofgroep. In de PPDB werden dezelfde toxiciteitsgegevens voor Eisenia foetida voor alle zes stoffen gegeven. Om deze reden zijn voor alle zes stoffen de toxiciteitsgegevens voor Eisenia foetida voor 'pyrethrins' gebruikt, zoals die in de EU/EFSA-toelatingsgegevens voor 'pyrethrins' zijn gevonden.

Soms zijn geen toxiciteitswaarden voor bodemorganismen vereist als een stof bijvoorbeeld als gewasbeschermingsmiddel toegepast wordt op het gewas en het transport van de stoffen naar bodem bij de beoogde toepassing(en) onwaarschijnlijk wordt geacht. Voor het grootste gedeelte ( 89 van de 108) van de in mest aangetroffen bestrijdingsmiddelen werden toxiciteitsgegevens voor ten minste één standaard bodemevertebraat gevonden, zodat voor deze stoffen een '(indicatieve) norm' voor bodemevertebraten kon worden afgeleid.

Voor drie stoffen werden gegevens ontleend aan ECHA-documenten, waaraan een PNEC voor bodem (piperonyl butoxide, norm $0.098 \mathrm{mg} / \mathrm{kg}$ ) of een 14 dagen LC50 voor een bodemorganisme (BAC-12, BAC-14, norm $125 \mathrm{mg} / \mathrm{kg}$ gelijk verondersteld aan de norm voor DDAC) kon worden ontleend. De norm voor piperonyl butoxide is gebaseerd op toxiciteitsgegevens voor een muggenlarve, voor DDAC is de norm gebaseerd op toxiciteitsgegevens voor een worm.

Voor de stoffen hexachloorbenzeen, $\mathrm{p}, \mathrm{p}^{\prime}$-DDT, permethrin-cis en permethrin-trans werden de gegevens aan de online database 'Pesticide Properties Database'

(http://sitem.herts.ac.uk/aeru/ppdb/index.htm) ontleend (voor beide permethrin isomeren werd dezelfde waarde voor permethrin uit de PPDB gebruikt).

Voor pentachlooraniline, pentachloorbenzeen en $\mathrm{p}, \mathrm{p}^{\prime}$-DDE werden getallen uit een (offline) eerdere versie van de PPDB gebruikt.

De chronische NOECworm voor pirimifos-methyl $(0.02 \mathrm{mg} / \mathrm{kg})$ is ontleend aan de US EPA-database. Het betreft een eindpunt (verstoring flux over membranen) dat niet gangbaar is als eindpunt in de risicobeoordeling, maar dat gezien het gebrek aan reguliere toxiciteitswaarden is gebruikt als conservatieve schatting van de toxiciteit en de voorkeur verdient boven een schatting van de toxiciteit op basis van een MTRwater. 
De waarde voor de chronische NOECworm voor cyfluthrin is ontleend aan de US EPA-database.

Weliswaar bevatte de PPDB-database een getal voor NOECworm, maar hier werd de NOEC gegeven als $>1000 \mathrm{mg} / \mathrm{kg}$, terwijl de EPA-database een concreet getal bevatte $(0.384 \mathrm{mg} / \mathrm{kg})$ dat gezien het verschil in grootte als conservatief kan worden beschouwd.

Geschatte waarden van MTRsediment zijn gebruikt voor bifenyl (norm: $0.51 \mathrm{mg} / \mathrm{kg}$ ), difenylamine (norm $0.212 \mathrm{mg} / \mathrm{kg}$ ), mefosfolan (norm: $0.0000213 \mathrm{mg} / \mathrm{kg}$ ) en vamidothion (norm $0.000572 \mathrm{mg} / \mathrm{kg}$ ). MTRs voor water zijn gebaseerd op toxiciteitsgegevens voor waterorganismen (vissen en kreeftachtigen). Uit de MTRs voor water zijn MTRs voor sediment geschat op basis van equilibrium partitie. 


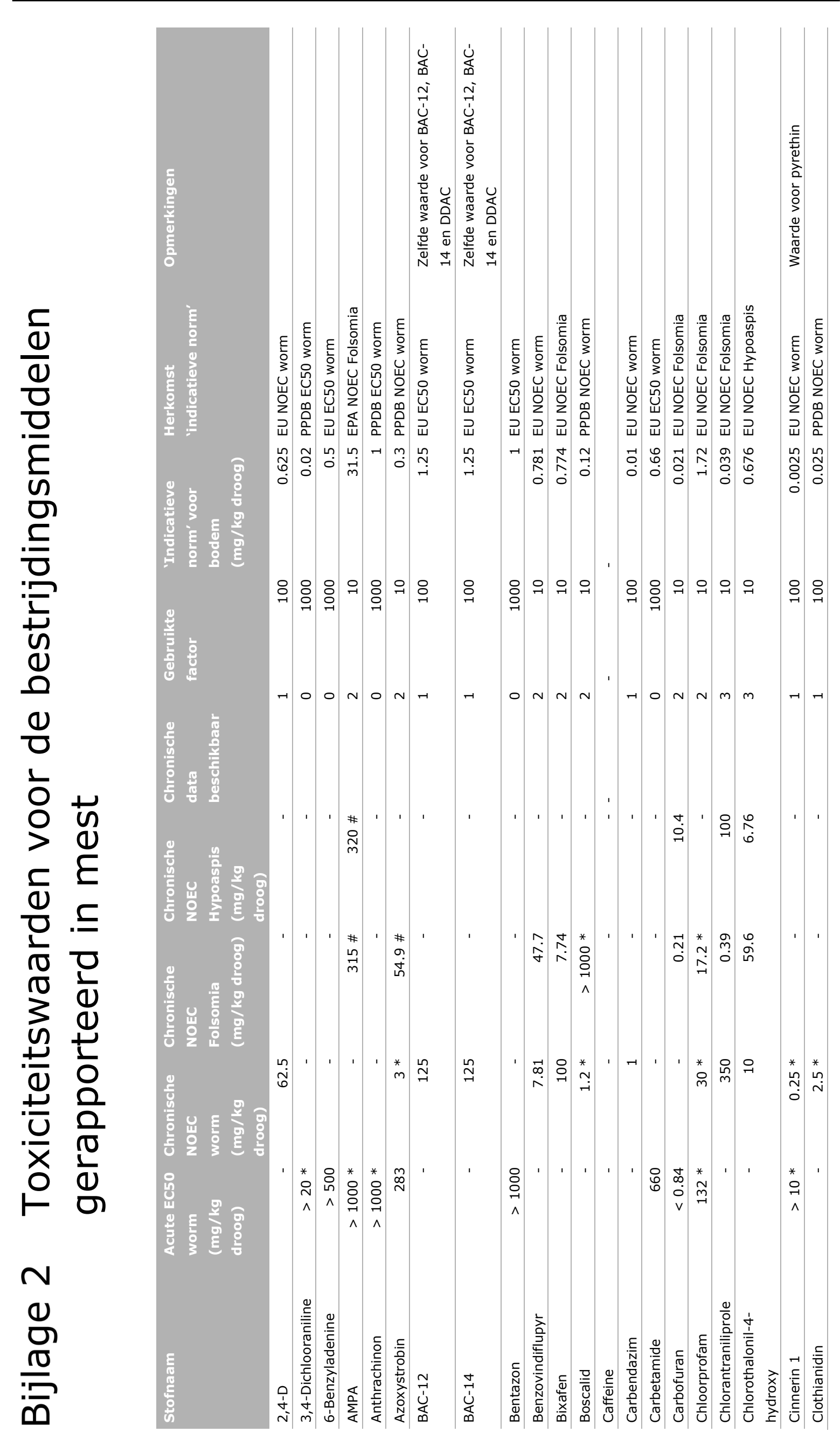




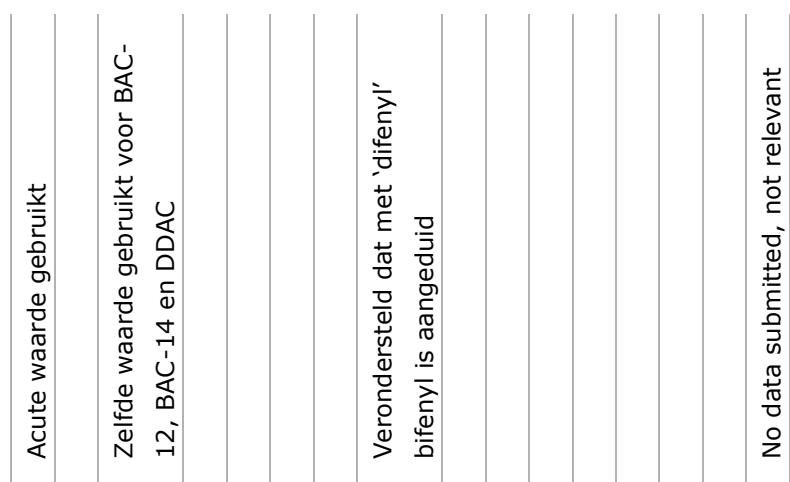

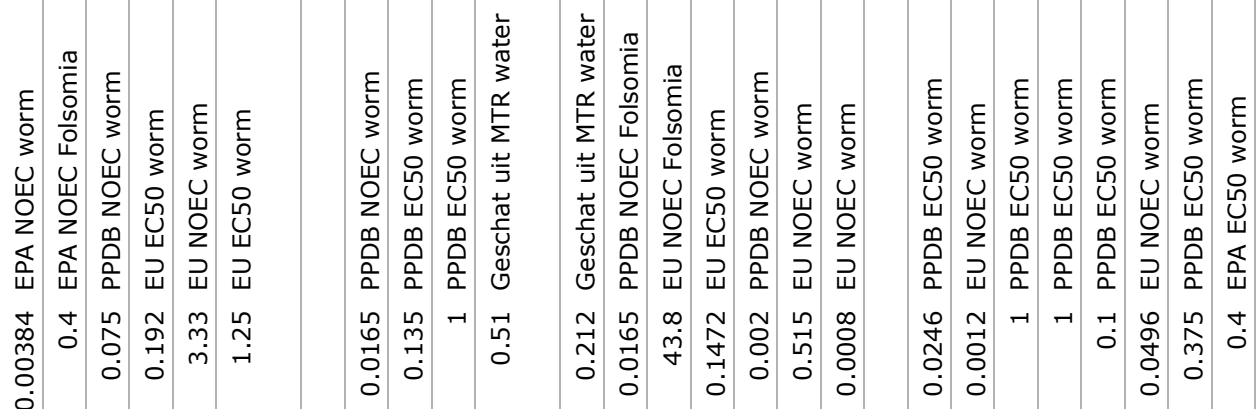

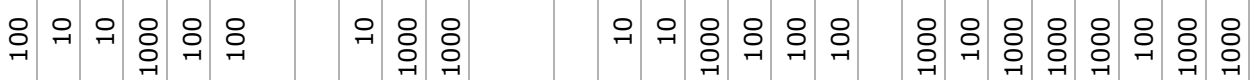

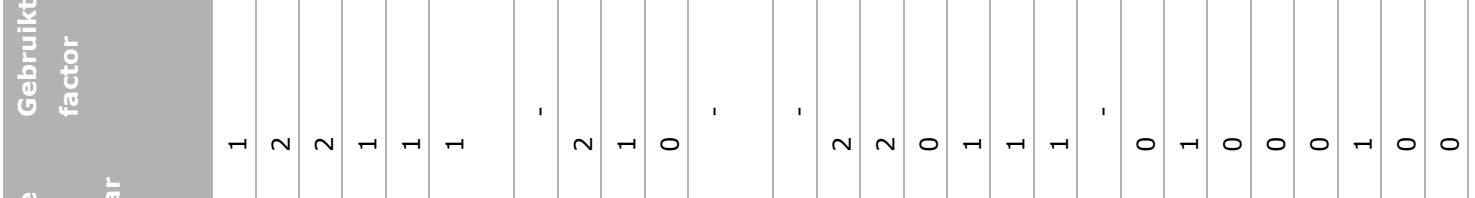

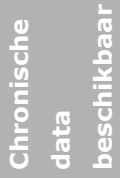

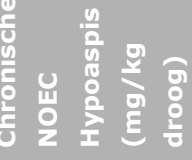

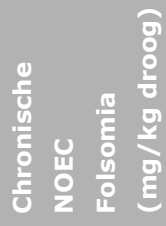

苦葛

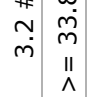

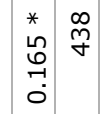

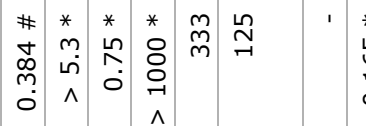

$\underset{0 .}{*}$

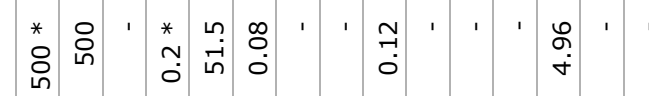

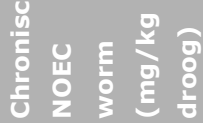

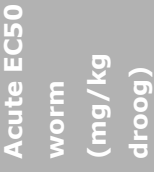

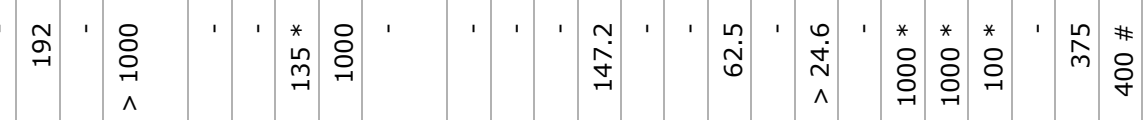

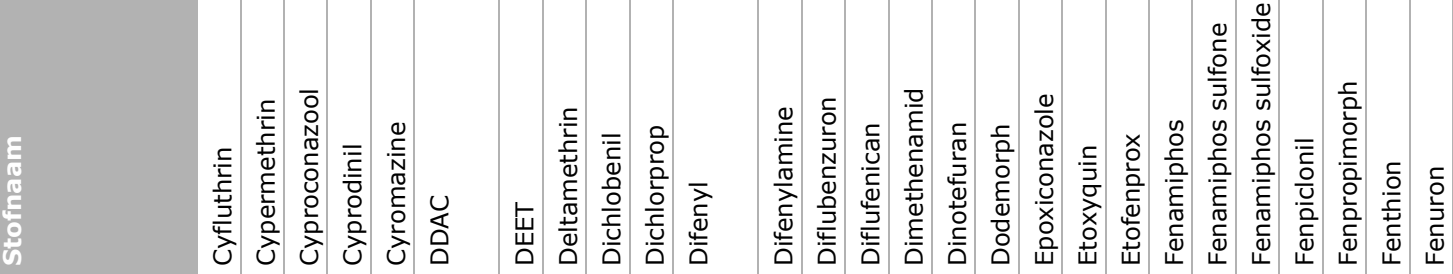




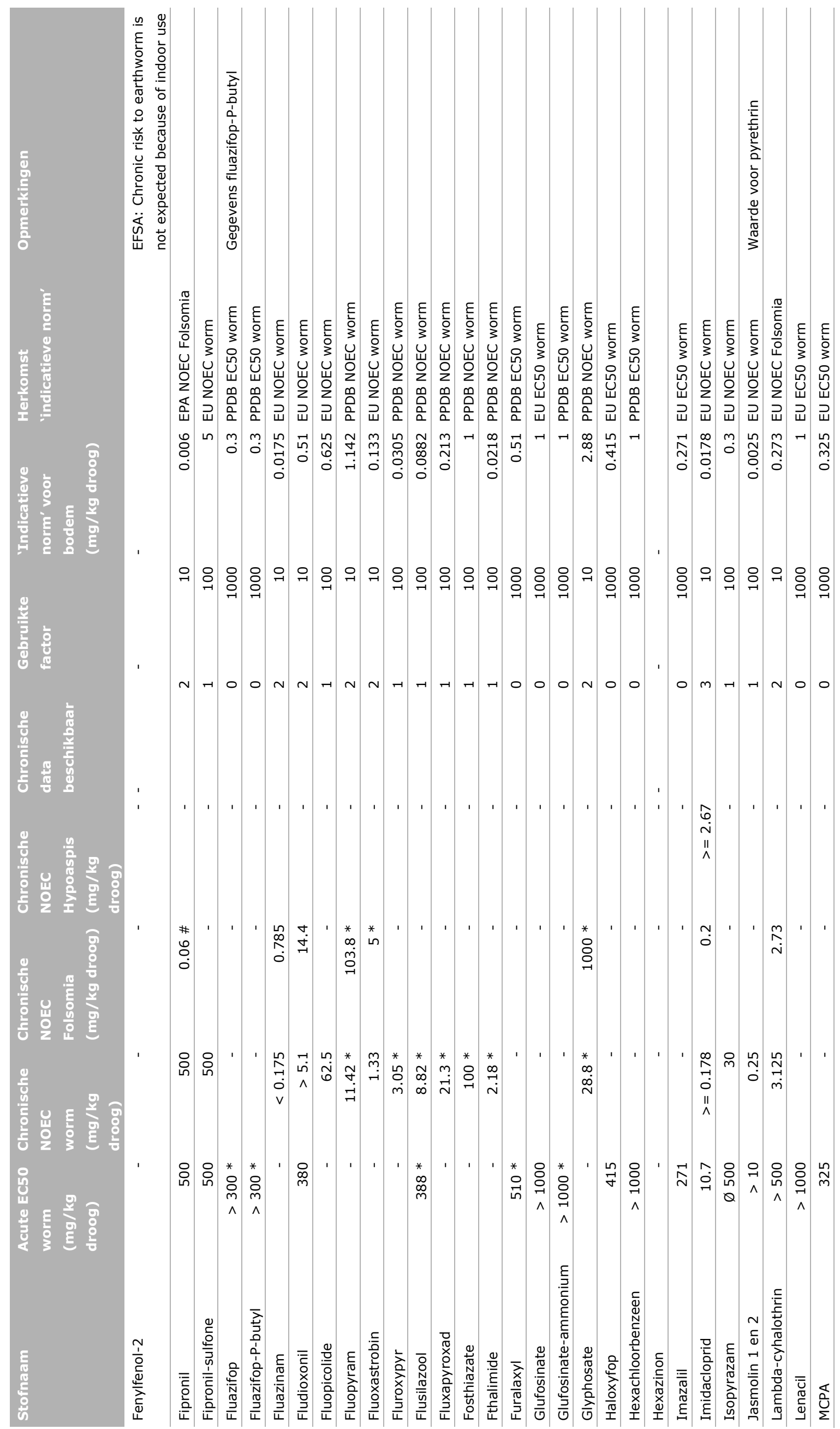




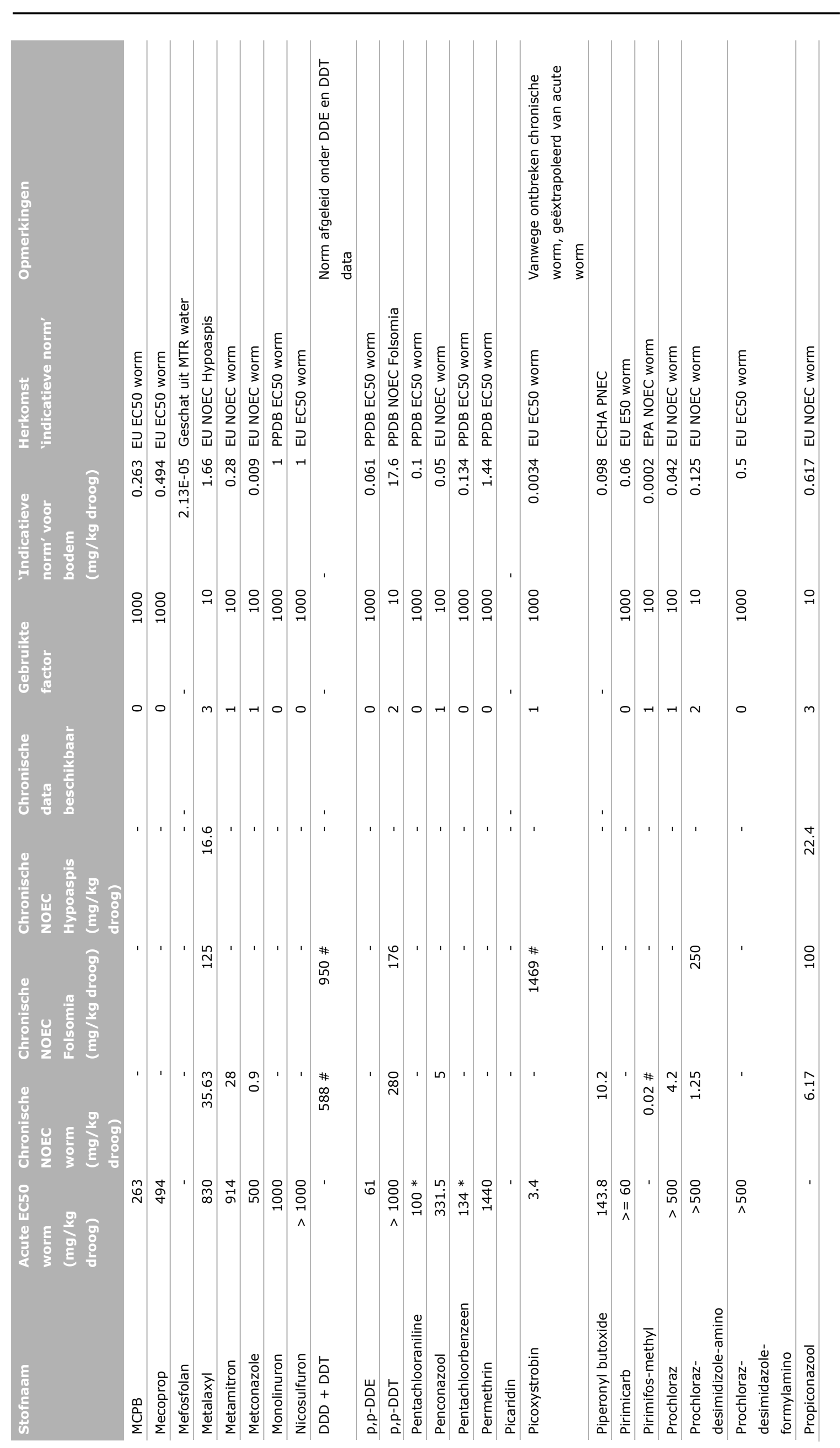




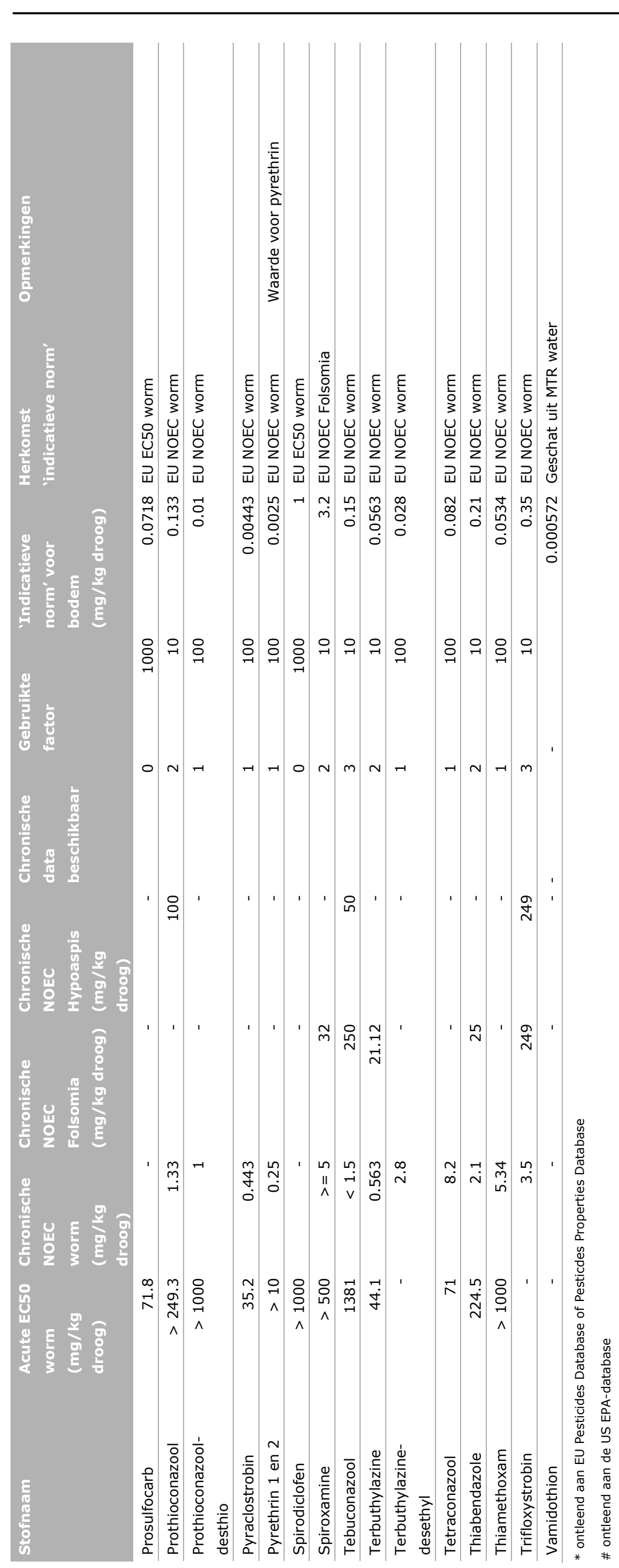

42 | Wageningen Environmental Research Rapport 3037 


\section{Bijlage 3 Toxiciteitswaarden voor standaard bodemevertebraten ontleend aan open literatuur en US EPA-database}

Indien geen waarde werd gevonden, is dit aangegeven met een '?'.

2-(2,4-Dichlorophenoxy)acetic acid

2d LC50 Eisenia fetida $=61.6$ AI ug/cm2 (Mortality) (Roberts and Dorough, 1984, Environ. Toxicol. Chem.3(1): 67-78

56d LOEL Eisenia fetida $=10 \mathrm{mg} / \mathrm{kg}$ dry soil (Progeny counts/numbers) (Correia and Moreira, 2010, Bull. Environ. Contam. Toxicol.85(3): 264-268)

\section{3,4-Dichlooraniline}

?

\section{6-Benzyladenine}

?

\section{AMPA}

56d EC50 Eisenia fetida $=654.7$ AI mg/kg dry soil (Reproduction) (Von Merey et al., 2016, Environ. Toxicol. Chem.35(11): 2742-2752)

28d NOEL Eisenia fetida $=198.1 \mathrm{AI} \mathrm{mg} / \mathrm{kg}$ dry soil (Progeny counts/numbers) (Von Merey et al., 2016, Environ. Toxicol. Chem.35(11): 2742-2752)

$28 \mathrm{~d}$ NOEL Folsomia candida $=315 \mathrm{mg} / \mathrm{kg}$ dry soil (Progeny counts/numbers and survival) (Von Merey et al., 2016, Environ. Toxicol. Chem.35(11): 2742-2752)

14d NOEL Hypoaspis aculeifer $=320 \mathrm{mg} / \mathrm{kg}$ dry soil (Progeny counts/numbers and survival) (Von Merey et al., 2016, Environ. Toxicol. Chem.35(11): 2742-2752)

\section{Anthrachinon}

?

\section{Azoxystrobin}

2d LC50 Eisenia fetida $=2.72 \mathrm{ug} / \mathrm{cm} 2$ (Mortality) (Wang et al., 2012. Chemosphere88(4): 484-491)

14d LC50 Eisenia fetida $=327.4 \mathrm{mg} / \mathrm{kg}$ dry soil (Mortality) (Wang et al., 2012. Chemosphere 88(4):

484-491)

7d LOEL Eisenia fetida $=0.1 \mathrm{mg} / \mathrm{kg}$ (genetic damage, Enzyme catalase, Reactive oxygen species)

(Han et al., 2014. Ecotoxicol. Environ. Saf.107:214-219)

28D EC20 Folsomia candida $=54.9 \mathrm{AI} \mathrm{mg} / \mathrm{kg}$ dry soil (Progeny counts/numbers) (Leitao et al., 2014.

Appl. Soil Ecol. 76(0): 124-131)

28D EC50 Folsomia candida $=92 \mathrm{AI} \mathrm{mg} / \mathrm{kg}$ dry soil (Progeny counts/numbers) (Leitao et al., 2014.

Appl. Soil Ecol. 76(0): 124-131)

BAC-12

$?$

BAC-14

?

\section{Bentazon}

2d LC50 Eisenia fetida $=3.27(2.50-4.28) \mathrm{kg} / \mathrm{ha}$ (Mortality) (Pizl 1988, Pedobiologia32(3/4): 227-232)

Benzovindiflupyr

?

Bixafen

?

Boscalid

?

\section{Caffeine}

2D NOEL Eisenia fetida $=19.3 \mathrm{ug} / \mathrm{cm} 2$ (Biochemistry Phenylalanine) (McKelvie, 2011. Environ.

Pollut.159(12): 3620-3626). 
2D LC50 Eisenia fetida $=58 \mathrm{ug} / \mathrm{cm} 2$ (Mortality) (Roberts and Dorough, 1984. Environ. Toxicol. Chem.3(1): 67-78)

\section{Carbendazim}

28d LOEC Eisenia andrei $=0.1 \mathrm{AI} \mathrm{mg} / \mathrm{kg}$ dry soil (growth biomass) (De Silva et al., 2009.

Chemosphere76(10): 1410-1415)

14d LOEL Eisenia andrei = 3.16 AI mg/kg soil (mortality) (Buch et al., 2013. Appl. Soil Ecol.69:32-38)

14d LOEL Eisenia fetida = $10 \mathrm{AI} \mathrm{mg} / \mathrm{kg}$ dry soil (population biomass) (Garcia 2004, Effects of

Pesticides on Soil Fauna: Development of Ecotoxicological Test Methods for Tropical Regions, Ecology and Development Series 19, Center for Development Research, Bonn, Germany:290 p.)

14d NOEL Folsomia candida $=<10 \mathrm{mg} / \mathrm{kg}$ dry soil (mortality and Reproduction) (Coja et al., 2006.

Ecotoxicology15(1): 61-72)

\section{Carbetamide}

?

\section{Carbofuran}

28d LOEC Eisenia andrei = 0.5 AI mg/kg dry soil (growth biomass) (De Silva 2009.

Chemosphere76(10): 1410-1415)

$56 \mathrm{~d}$ LOEC Eisenia andrei $=0.5 \mathrm{AI} \mathrm{mg} / \mathrm{kg}$ dry soil (reproduction progeny counts/numbers) (De Silva 2009. Chemosphere76(10): 1410-1415)

28d NOEC Eisenia andrei $=<0.5 \mathrm{AI} \mathrm{mg} / \mathrm{kg}$ dry soil (growth biomass) (De Silva 2009.

Chemosphere76(10): 1410-1415)

60d NOEL Eisenia fetida $=0.2 \mathrm{mg} / \mathrm{kg}$ media (Sexual development) (Bouwman and Reinecke 1987.

Bull. Environ. Contam. Toxicol.38(1): 171-178)

14d EC50 Folsomia candida $=0.066 \mathrm{mg} / \mathrm{L}$ (Immobile) (Houx et al. 1996. Arch. Environ. Contam.

Toxicol.30(1): 9-14)

210d NOEL Hypoaspis aculeifer = 2.24 AI kg/ha (population abundance) (Martin 1978. N. Z. J. Agric. Res.21:307-319).

\section{Chloorprofam > Chlorpropham}

$5 \mathrm{dNOEL}$ Eisenia veneta $=0.16 \mathrm{mg} / \mathrm{ml}$ (Immunity, general) (Bunn et al., 1996. Bull. Environ. Contam. Toxicol.57(4): 632-639).

$5 \mathrm{dLOEL}$ Eisenia veneta $=1.23 \mathrm{mg} / \mathrm{ml}$ (Immunity, general) (Bunn et al., 1996. Bull. Environ. Contam. Toxicol.57(4): 632-639).

\section{Chlorantraniliprole}

7dLOEL Eisenia fetida = $5 \mathrm{AI}$ ug/kg dry soil (Enzyme(s) catalase) (Hackenberger et al., 2018.

Ecotoxicol. Environ. Saf.148:480-489).

\section{Chlorothalonil-4-hydroxy > Chlorothalonil}

56d NOEC Eisenia andrei $=5 \mathrm{AI} \mathrm{mg} / \mathrm{kg}$ dry soil (Reproduction Progeny counts/numbers) (Leitao et al. 2014. Appl. Soil Ecol.76(0): 124-131).

28d NOEC Eisenia andrei $=50 \mathrm{AI} \mathrm{mg} / \mathrm{kg}$ dry soil (population biomass) (Leitao et al., 2014. Appl. Soil Ecol.76(0): 124-131).

37d LOEL Eisenia fetida $=0.849 \mathrm{~g} / 4719 \mathrm{~cm}^{3}$ soil (Mortality survival) (Roark and Dale, 1979. Ark. Acad. Sci. Proc.33:71-79).

101d NOEL Eisenia fetida $=0.1 \%$ (Mortality survival) (Roark and Dale, 1979. Ark. Acad. Sci.

Proc.33:71-79).

28d NOEL Folsomia candida $=19.4$ AI mg/kg soil (Mortality survival) (Simoes et al., 2019. Sci. Total Environ.675:90-97).

28d EC50 Folsomia candida = 14.9 AI mg/kg soil (Reproduction Fecundity) (Simoes et al., 2019. Sci. Total Environ.675:90-97).

\section{Cinnerin 1}

?

\section{Clothianidin}

56d EC50 Eisenia fetida $=0.368 \mathrm{mg} / \mathrm{kg}$ soil (Reproduction Progeny counts/numbers) (Wang et al., 2015. Chemosphere132:120-126)

14d LC50 Eisenia fetida $=0.93 \mathrm{mg} / \mathrm{kg}$ soil (Mortality) (Wang et al., 2015. Chemosphere132:120-126) 14d LOEC Eisenia fetida $=503 \mathrm{ng} / \mathrm{g} \mathrm{dw}$ soil (Growth, general) (De Perre et al., 2015. Environ. Toxicol. Chem.34(2): 258-265).

14d NOEC Eisenia fetida $=256 \mathrm{ng} / \mathrm{g} \mathrm{dw}$ soil (Growth, general) (De Perre et al., 2015. Environ. Toxicol. Chem.34(2): 258-265). 
56d NOEL Eisenia fetida $=0.01 \mathrm{mg} / \mathrm{kg}$ soil (Weight) (Wang et al., 2015. Chemosphere132:120-126).

\section{Cyfluthrin}

14d NOEC Eisenia fetida $=0.384 \mathrm{AI}$ ug/g dry soil (Growth Weight) (De Perre et al., 2015. Environ.

Toxicol. Chem.34(1): 197-207).

\section{Cypermethrin}

28/56d NOEC Eisenia fetida ssp. Andrei $=40 \mathrm{mg} / \mathrm{kg}$ (Reproduction Progeny counts/numbers) (Zhou et al., 2011. J. Environ. Sci.23(4): 676-680).

21d NOEC Folsomia candida $=4 \mathrm{mg} / \mathrm{kg}$ (Reproduction Fecundity) (Sorensen and Holmstrup, 2005. Ecotoxicol. Environ. Saf.60(2): 132-139).

21d NOEC Folsomia candida $=8 \mathrm{mg} / \mathrm{kg}$ (Mortality) (Sorensen and Holmstrup, 2005. Ecotoxicol.

Environ. Saf.60(2): 132-139).

\section{Cyproconazool > Cyproconazole}

14D LC50 Eisenia fetida $=211.8 \mathrm{mg} / \mathrm{kg}$ dry soil (Mortality) (Wang et al., 2012. Chemosphere88(4): 484-491).

\section{Cyprodinil}

?

\section{Cyromazine}

?

\section{DDAC}

?

\section{DEET}

?

\section{Deltamethrin}

42d NOEL Eisenia fetida $=50 \mathrm{mg} / \mathrm{kg}$ dry soil (growth Weight) (Shi et al., 2007. Pestic. Biochem. Physiol.89(1): 31-38).

28d EC10 Folsomia candida $=0.20(0.0-0.61) \mathrm{mg} / \mathrm{kg}$ soil (Kamoen et al., 2017)

28d NOEL Hypoaspis aculeifer $=3.2 \mathrm{mg} / \mathrm{kg}$ soil (Reproduction Progeny counts/numbers) (Owojori et al., 2014. Environ. Toxicol. Chem.33(1): 230-237).

28d EC50 Hypoaspis aculeifer $=9.88 \mathrm{mg} / \mathrm{kg}$ soil (Reproduction Progeny counts/numbers) (Owojori et al., 2014. Environ. Toxicol. Chem.33(1): 230-237).

Dichlobenil > Casoron

28d LC50 Eisenia fetida $=270$ mg/kg (mortality) (Ballhorn et al., 1984. Forschungsbericht No.106 04 011/02, Umweltbundesamt Berlin (): (OECDG Data File):201 p.).

\section{Dichlorprop}

?

\section{Difenyl > Diphenyl?}

Onduidelijk welke stof het moet zijn

Difenylamine > Diphenylamine

?

\section{Diflubenzuron}

121.7d LOEL Folsomia quadrioculata $=25 \mathrm{AI} g /$ ha (Population abundance) (Becket al., 2004. Eur. J. Soil Sci.40(1): 55-62).

13-45d NOEL Hypoaspis sp. $=4 \mathrm{~g} / \mathrm{m} 2$ (Population abundance) (Ali et al., 1999. Exp. Appl.

Acarol.23(1): 65-77).

\section{Diflufenican}

?

\section{Dimethenamid}

?

\section{Dinotefuran}

?

Dodemorph

?

\section{Epoxiconazole}

14d LC50 Eisenia fetida $=33.1 \mathrm{mg} / \mathrm{kg}$ dry soil (Mortality) (Wang et al., 2012. Chemosphere88(4): 484-491).

Etoxyquin > Ethoxyquin 
$?$

\section{Etofenprox}

?

\section{Fenamiphos}

28d LC50 = Eisenia fetida 318 mg/kg soil (Mortality) (Heimbach 1984. Pestic. Sci.15:605-611)

Fenamiphos sulfone

?

Fenamiphos sulfoxide

?

Fenpiclonil

$?$

Fenpropimorph

?

Fenthion

14d LC50 Eisenia fetida $=243.7 \mathrm{mg} / \mathrm{kg}$ (Mortality) (Wang et al., 2012 Ecotoxicol. Environ.

Saf. 79:122-128).

Fenuron

14d LC50 Eisenia fetida $=399.9 \mathrm{mg} / \mathrm{kg}$ dry soil (Mortality) (Wang et al., 2012. Chemosphere88(4):

484-491).

Fenylfenol-2

?

Fipronil

56d EC50 Eisenia andrei $=>1000 \mathrm{AI} \mathrm{mg} / \mathrm{kg}$ dry soil (Reproduction Progeny counts/numbers) (Alves et al., 2013. Chemosphere90(11): 2674-2682).

56d LOEC Eisenia andrei $=62.5 \mathrm{AI} \mathrm{mg} / \mathrm{kg}$ dry soil (Reproduction Progeny counts/numbers) (Alves et al., 2013. Chemosphere90(11): 2674-2682).

56d NOEC Eisenia andrei $=1 \mathrm{AI} \mathrm{mg} / \mathrm{kg}$ dry soil (Reproduction Progeny counts/numbers) (Alves et al., 2013. Chemosphere90(11): 2674-2682).

14d LC50 Folsomia candida $=59.62 \mathrm{AI} \mathrm{mg} / \mathrm{kg}$ dry soil (Mortality) (Alves et al., 2014. Ecotoxicol. Environ. Saf.105:65-71).

28d NOEC Folsomia candida $=0.06 \mathrm{AI} \mathrm{mg} / \mathrm{kg}$ dry soil (Reproduction Progeny counts/numbers) (Alves et al., 2014. Ecotoxicol. Environ. Saf.105:65-71).

Fipronil-sulfone

?

Fluazifop > Fluazifop-P-Butyl

14d LC50 Eisenia fetida $=4.16 .4 \mathrm{mg} / \mathrm{kg}$ dry soil (Mortality) (Wang et al., 2012. Chemosphere88(4): 484-491)

Fluazinam

?

Fludioxonil

?

Fluopicolide

?

Fluopyram

?

\section{Fluoxastrobin}

7d LOEL Eisenia fetida $=0.1 \mathrm{AI} \mathrm{mg} / \mathrm{kg}$ soil (Reactive oxygen species) (Zhang et al., 2018. Sci. Total Environ.642:567-573).

28d NR-ZERO Eisenia fetida $=2.5 \mathrm{AI} \mathrm{mg} / \mathrm{kg}$ soil (Mortality) (Zhang et al., 2018. Sci. Total Environ.642:567-573).

\section{Fluroxypyr}

$?$

Flusilazool > Flusilazole

?

Fluxapyroxad

? 


\section{Fosthiazate}

?

\section{Fthalimide $>$ Phthalimide}

14d LC50 Eisenia fetida $=451.7 \mathrm{mg} / \mathrm{kg}$ dry soil (Mortality) (Haque and Ebing 1983. J. Plant Dis.

Prot.90(4): 395-408)

\section{Furalaxyl}

?

\section{Glufosinate}

?

\section{Glufosinate-ammonium}

14d LC50 Eisenia fetida $=162.2 \mathrm{mg} / \mathrm{kg}$ dry soil (Mortality) (Wang et al., 2012. Chemosphere88(4): 484-491).

\section{Glyphosate}

14d NOEL Eisenia andrei $=47 \mathrm{AI} \mathrm{mg} / \mathrm{kg}$ soil (Mortality) (Buch et al., 2013. Appl. Soil Ecol.69:32-38). $56 \mathrm{~d}$ LOEL Eisenia fetida $=10 \mathrm{mg} / \mathrm{kg}$ dry soil (Reproduction Progeny counts/numbers) (Correia and Moreira 2010, Bull. Environ. Contam. Toxicol.85(3): 264-268).

70d NOEL Eisenia fetida $=500 \mathrm{mg} / \mathrm{kg}$ soil (Reproduction Fecundity) (Garcia-Torres et al., 2014. Bull. Environ. Contam. Toxicol.93(2): 209-214).

56d NOEL Eisenia hortensis $=2160 \mathrm{ug} / \mathrm{kg}$ dry soil (Weight Growth and Reproduction Progeny counts/numbers) (Hackenberger et al., 2018. Chemosphere208:722-730).

28d NOEL Folsomia candida $=14.08 \mathrm{AI} \mathrm{mg} / \mathrm{kg}$ soil (Mortality Survival and Reproduction Fecundity) (Simoes et al., 2019. Sci. Total Environ.675:90-97).

\section{Haloxyfop}

?

\section{Hexachloorbenzeen > Hexachlorobenzene}

28d LC50 Eisenia fetida $=>1000 \mathrm{mg} / \mathrm{kg}$ (Mortality) (Ballhorn et al., 1984. Forschungsbericht No.106 04 011/02, Umweltbundesamt Berlin (): (OECDG Data File):201 p.).

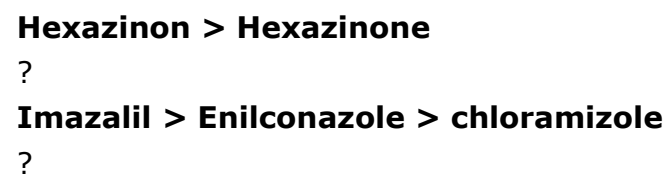


?

Mecoprop

$?$

Mefosfolan > Mephosfolan

$?$

Metalaxyl

?

Metamitron

14d LC50 Eisenia fetida $=195.2 \mathrm{mg} / \mathrm{kg}$ dry soil (Mortality) (Wang et al., 2012, Chemosphere88(4): 484-491).

Metconazole

?

Monolinuron

?

Nicosulfuron

?

DDD + DDT > DDT

56d EC50 Eisenia fetida $=588 \mathrm{mg} / \mathrm{kg}$ dry soil (Reproduction Progeny counts/numbers) (Hund-Rinke and Simon 2005, J. Soils Sediments5(1): 59-65).

28d EC50 Folsomia candida $=950 \mathrm{mg} / \mathrm{kg}$ dry soil (Reproduction Progeny counts/numbers) (HundRinke and Simon 2005, J. Soils Sediments5(1): 59-65).

p,p-DDE

?

p,p-DDT

?

Pentachlooraniline $>$ Pentachloroaniline $>\mathbf{2}, \mathbf{3}, \mathbf{4}, \mathbf{5}, \mathbf{6}$-Pentachlorobenzenamine

14d LC50 Eisenia andrei $=1014$ mg/kg dry soil (Mortality) (Van Gestel and Ma 1993, Water Air Soil Pollut.69(3/4): 265-276).

Pentachloorbenzeen > Pentachlorobenzene

14d LC50 Eisenia andrei $=134$ mg/kg (Mortality) (Van Gestel et al., 1991, Sci. Total

Environ.109/110:589-604).

\section{Permethrin}

2d LC50 Eisenia fetida $=>1000$ AI ug/cm2 (Mortality) (Roberts and Dorough 1984, Environ. Toxicol. Chem.3(1): 67-78).

Picaridin > Icaridin

?

Picoxystrobin

56d EC50 Eisenia fetida $=4.8 \mathrm{AI}$ umol/kg dry soil (Growth weight) (Schnug et al., 2014, Soil Biol. Biochem.74:115-126).

14d LC50 Eisenia fetida $=7.22 \mathrm{mg} / \mathrm{kg}$ dry soil (Mortality) (Wang et al 2012., Chemosphere88(4): 484-491).

56d EC50 Folsomia fimetaria = $>4000$ AI umol/kg dry soil (Population abundance) (Schnug et al., 2014, Soil Biol. Biochem.74:115-126).

\section{Piperonyl butoxide}

2d LC50 Eisenia fetida $=432 \mathrm{mg} / \mathrm{L}$ (Mortality) (Roberts and Dorough 1984. Environ. Toxicol.

Chem.3(1): 67-78).

Pirimicarb

$5 \mathrm{~d}$ NOEL Eisenia veneta $=0.013 \mathrm{mg} / \mathrm{ml}$ (Immunity, general) (Bunn et al., 1996. Bull. Environ.

Contam. Toxicol.57(4): 632-639).

Pirimifos-methyl > Pirimiphos-methyl

28d LOEL Eisenia andrei $=0.02 \mathrm{AI} \mathrm{mg/kg}$ (Physiology Flux, across membranes) (Velki and Hackenberger 2013, Chemosphere90(3): 1216-1226).

\section{Prochloraz}

?

Prochloraz-desimidizole-amino

? 


\section{Prochloraz-desimidazole-formylamino \\ ? \\ Propiconazool > Propiconazole}

7d NOEL Eisenia fetida = 83.3 AI ug/kg dry soil (Enzyme Catalase) (Hackenberger et al. 2018, Ecotoxicol. Environ. Saf.148:480-489).

\section{Prosulfocarb}

$?$

Prothioconazool > Prothioconazole

?

\section{Prothioconazool-desthio}

?

Pyraclostrobin

?

Pyrethrin (1 en 2)

?

\section{Spirodiclofen}

28d NOEL Eisenia andrei = 0.6 AI mg/kg dry soil (Growth Weight) (Santos et al., 2011, Appl. Soil Ecol.48(3): 294-300).

\section{Spiroxamine}

?

Tebuconazool > Tebuconazole

28D NOEL Eisenia fetida $=28 \mathrm{mg} / \mathrm{kg}$ soil (Enzyme Catalase) (Chen et al., 2018, Sci. Rep.8(2967): 9 p.).

14d LC50 Eisenia fetida $=180 \mathrm{mg} / \mathrm{kg}$ dry wt (Mortality) (Rico et al., 2016, Ecotoxicol. Environ. Saf.127:222-229).

28d NOEC Folsomia candida $=50 \mathrm{mg} / \mathrm{kg}$ dry soil (Reproduction Progeny counts/numbers) (Guimaraes et al., 2018, Ecotoxicol. Environ. Saf.165:284-290)

\section{Terbuthylazine}

56d LOEL Eisenia andrei $=1 \mathrm{ug} / \mathrm{g}$ dry fd (Net Reproductive Rate) (Brunninger et al., 1994, Biol. Fertil. Soils18:83-88).

140d NOEL Eisenia andrei = 10 AI ug/g dry fd (Mortality Hatch) (Viswanathan, 1997,

Chemosphere35(1-2): 323-334).

\section{Terbuthylazine-desethyl}

?

Tetraconazool > tetraconazole

?

\section{Thiabendazole}

29d LOEL Eisenia fetida $0.283 \mathrm{~g} / 4719 \mathrm{~cm} 3$ soil (Mortality Survival) (Roark and Dale, 1979, Ark. Acad. Sci. Proc.33:71-79).

\section{Thiamethoxam}

56d NOEC Eisenia andrei $=250 \mathrm{AI} \mathrm{mg} / \mathrm{kg}$ dry soil (Reproduction Progeny counts/numbers) (Alves et al., 2013, Chemosphere90(11): 2674-2682).

28d NOEC Folsomia candida $=1 \mathrm{AI} \mathrm{mg} / \mathrm{kg}$ dry soil (Reproduction Progeny counts/numbers) (Alves et al., 2014, Ecotoxicol. Environ. Saf.105:65-71).

\section{Trifloxystrobin}

14d LC50 Eisenia fetida $=401.3 \mathrm{mg} / \mathrm{kg}$ dry soil (Mortality) (Wang et al., 2012, Chemosphere88(4): 484-491).

\section{Vamidothion}




\section{Bijlage 4 Vergelijk chronische toxiciteit worm (uit NOEC of EC50/10) en MTRsediment}

Voor de stoffen waar zowel een chronische toxiciteitswaarde voor een bodemevertebraat als een MTRwaarde beschikbaar is, is een vergelijking gemaakt in hoeverre de MTR sediment (in dit rapport 'water' genoemd omdat dit vanuit de aquatische risicobeoordeling afkomstig is en zo meer onderscheidend is van de MTR $_{\text {bodem }}$ ) afwijkt van deze experimenteel bepaalde chronische toxiciteitswaarde. Met uitzondering van één enkele stof, is de MTR $_{\text {water }}$ in alle gevallen veel conservatiever.

\begin{tabular}{|c|c|c|c|}
\hline Stofnaam & $\begin{array}{l}\text { Chron. Tox worm } \\
\text { (mg/kg droog) }\end{array}$ & $\begin{array}{r}\text { MTR sediment RIVM } \\
(\mathrm{mg} / \mathrm{kg})\end{array}$ & Verhouding \\
\hline $2,4-D$ & 62.5 & 0.035 & 1786 \\
\hline 2,4-Dichlooraniline & 2 & 0.12 & 16.7 \\
\hline AMPA & 100 & 22.8 & 4.39 \\
\hline Antrachinon & 100 & 0.0129 & 7752 \\
\hline Boscalid & 1.2 & 0.026 & 46.2 \\
\hline Carbofuran & 0.84 & 0.002 & 420 \\
\hline Cypermethrin & 5.3 & 0.0004 & 13250 \\
\hline Deltamethrin & 0.165 & 0.00054 & 306 \\
\hline Fenthion & 37.5 & 0.0004 & 93750 \\
\hline Fipronil & 1000 & 0.000004 & $2.5 \mathrm{E} 8$ \\
\hline Hexachloorbenzeen & 100 & 0.005 & 20000 \\
\hline Lambda-cyhalothrin & 3.125 & 0.000046 & 67935 \\
\hline Metamitron & 28 & 0.095 & 295 \\
\hline Penconazool & 5 & 0.17 & 29.4 \\
\hline Pentachlooraniline & 10 & 0.06 & 167 \\
\hline Pentachloorbenzeen & 13.4 & 0.1 & 134 \\
\hline Picoxystrobine & 0.34 & 0.001 & 340 \\
\hline Pirimicarb & 6 & 0.002 & 3000 \\
\hline Tebuconazool & 1.5 & 2.7 & 0.55 \\
\hline Thiamethoxam & 5.34 & 0.0026 & 2054 \\
\hline
\end{tabular}




\section{Bijlage 5 Toelichting combinatietoxiciteit en het 'Toxic Units'-concept}

Onderstaande tekst is integraal overgenomen uit Weltje et al. (1995), RIVM-rapport 719102043, pagina's 19-20.

Het toxic unit-concept heeft als doel stoffen optelbaar te maken, zodat de concentratie-additiehypothese getest kan worden. Daartoe worden stoffen geschaald in toxiciteit, door middel van een van tevoren gekozen toxicologisch eindpunt (een ECx die gelijkgesteld wordt aan een toxic unit (TU)). Alle concentraties van een stof i zijn nu uit te drukken in fracties van de ECx, i (in dimensieloze toxic units) met behulp van formule (1), waarin $\mathrm{Ci}$ staat voor de concentratie van stof i.

$$
T U_{i}=\frac{C_{i}}{E C_{X, i}}
$$

De concentraties van alle aanwezige componenten in een mengsel kunnen op deze manier omgerekend worden naar toxic units, mits hun individuele toxicologische eindpunten bekend zijn uit eerdere of (bij voorkeur) synchroon lopende enkelvoudige blootstellingsexperimenten. Een vergelijkbare benadering wordt ook toegepast bij groepen organochloorverbindigen (PCDD en PCB) onder de naam Toxiciteits Equivalentie Factor (TEF), waarmee aangegeven wordt hoeveel minder toxisch een bepaalde congeneer is dan 2,3,7,8-TCDD (Van Zorge et al., 1989).

Onder aanname van concentratie-additie geldt voor een mengsel van $n$ stoffen formule (2).

$$
T U_{\text {mix }}=\sum_{i=1}^{n} T U i
$$

Als de concentratie-additie-aanname opgaat, heeft een mengsel met een totaalconcentratie van een TU een effect behorende bij het gekozen toxicologische eindpunt (bijv. EC50). In de praktijk wordt dit model vaak toegepast op equitoxische mengsels; dat zijn mengsels waarin elk van de aanwezige stoffen vertegenwoordigd is met eenzelfde fractie van zijn ECx. De verwachting is dat interacties tussen stoffen het best aantoonbaar zijn met equitoxische mengsels, omdat dan beide stoffen in gelijke effect-doses aanwezig zijn volgens de concentratie-additie-hypothese. 


\section{Bijlage 6 Berekende Toxic Units op basis van gerapporteerde gehalten in mest en de indicatieve norm}

Waar of geen gehalten van middelen uitgedrukt in droog gewicht waren gerapporteerd of waar geen toxiciteitswaarden van beschikbaar waren, was het niet mogelijk om een TU te berekenen (blanco cel).

\begin{tabular}{|c|c|c|c|}
\hline Bedrijf & Matrix & Middel & $\begin{array}{l}\text { Toxic Unit } \\
\text { (op basis van } \\
\text { droog gewicht) }\end{array}$ \\
\hline 2 & Vaste mest & 2_4-D (vrije zuur) & 0.000 \\
\hline 2 & Vaste mest & AMPA & \\
\hline 2 & Vaste mest & Antraquinon & 0.000 \\
\hline 2 & Vaste mest & Bixafen & 0.001 \\
\hline 2 & Vaste mest & Boscalid & 0.000 \\
\hline 2 & Vaste mest & Caffeine & \\
\hline 2 & Vaste mest & DIFENYL & 0.000 \\
\hline 2 & Vaste mest & Fthalimide (afbr. folpet) & 0.014 \\
\hline 2 & Vaste mest & Glufosinate-ammonium & \\
\hline 2 & Vaste mest & Glyphosate & \\
\hline 2 & Vaste mest & Prothioconazole & 0.016 \\
\hline 2 & Vaste mest & Prothioconazole-desthio & 0.012 \\
\hline 3 & Drijfmest & AMPA & \\
\hline 3 & Drijfmest & Antraquinon & 0.001 \\
\hline 3 & Drijfmest & Bixafen & 0.000 \\
\hline 3 & Drijfmest & Boscalid & 0.001 \\
\hline 3 & Drijfmest & Caffeine & \\
\hline 3 & Drijfmest & Chloorprofam & 0.000 \\
\hline 3 & Drijfmest & Chlorothalonil-4-hydroxy & \\
\hline 3 & Drijfmest & Cyproconazool & 0.001 \\
\hline 3 & Drijfmest & Deet & \\
\hline 3 & Drijfmest & DIFENYL & 0.001 \\
\hline 3 & Drijfmest & Epoxiconazole & 4.169 \\
\hline 3 & Drijfmest & Etofenprox & 0.013 \\
\hline 3 & Drijfmest & Fenylfenol-2 & \\
\hline 3 & Drijfmest & Fluxapyroxad & 0.007 \\
\hline 3 & Drijfmest & Glufosinate-ammonium & \\
\hline 3 & Drijfmest & Glyphosate & \\
\hline 3 & Drijfmest & Lambda-cyhalothrin & 0.006 \\
\hline 3 & Drijfmest & MCPA (vrije zuur) & 0.001 \\
\hline 3 & Drijfmest & Metconazole & 0.061 \\
\hline 3 & Drijfmest & Pentachloorbenzeen & 0.006 \\
\hline 3 & Drijfmest & Picoxystrobin & 0.468 \\
\hline 3 & Drijfmest & Prochloraz & 0.008 \\
\hline 3 & Drijfmest & Prochloraz desimidazole-amino & 0.108 \\
\hline 3 & Drijfmest & Procloraz desimadazole-formylamino & 0.004 \\
\hline 3 & Drijfmest & Prothioconazole-desthio & 0.020 \\
\hline 3 & Drijfmest & Tebuconazole & 0.002 \\
\hline 4 & Drijfmest & AMPA & \\
\hline 4 & Drijfmest & Antraquinon & 0.001 \\
\hline 4 & Drijfmest & Benzovindiflupyr & 0.003 \\
\hline 4 & Drijfmest & Bixafen & 0.003 \\
\hline 4 & Drijfmest & Boscalid & 0.059 \\
\hline
\end{tabular}




\begin{tabular}{|c|c|c|c|}
\hline Bedrijf & Matrix & Middel & $\begin{array}{l}\text { Toxic Unit } \\
\text { (op basis van } \\
\text { droog gewicht) }\end{array}$ \\
\hline 4 & Drijfmest & Chlorothalonil-4-hydroxy & 0.0002 \\
\hline 4 & Drijfmest & DIFENYL & 0.002 \\
\hline 4 & Drijfmest & Epoxiconazole & 1.208 \\
\hline 4 & Drijfmest & Fenpropimorph & 0.049 \\
\hline 4 & Drijfmest & Fenylfenol-2 & \\
\hline 4 & Drijfmest & Fluroxypyr (vrije zuur) & 0.075 \\
\hline 4 & Drijfmest & Glufosinate-ammonium & \\
\hline 4 & Drijfmest & Glyphosate & \\
\hline 4 & Drijfmest & MCPA (vrije zuur) & 0.001 \\
\hline 4 & Drijfmest & Piperonyl-butoxide & 0.039 \\
\hline 4 & Drijfmest & Prothioconazole & 0.025 \\
\hline 4 & Drijfmest & Prothioconazole-desthio & 0.060 \\
\hline 4 & Drijfmest & Tebuconazole & 0.002 \\
\hline 5 & Drijfmest & AMPA & \\
\hline 5 & Drijfmest & Antraquinon & 0.001 \\
\hline 5 & Drijfmest & Caffeine & \\
\hline 5 & Drijfmest & Carbofuran & 0.023 \\
\hline 5 & Drijfmest & DIFENYL & 0.001 \\
\hline 5 & Drijfmest & Fthalimide (afbr. folpet) & 0.092 \\
\hline 5 & Drijfmest & Glufosinate-ammonium & \\
\hline 5 & Drijfmest & Glyphosate & \\
\hline 5 & Drijfmest & Imazalil & 0.003 \\
\hline 5 & Drijfmest & Pentachloorbenzeen & 0.008 \\
\hline 6 & Drijfmest & 6-Benzyladenine & 0.037 \\
\hline 6 & Drijfmest & AMPA & \\
\hline 6 & Drijfmest & Antraquinon & 0.003 \\
\hline 6 & Drijfmest & Bentazon & 0.000 \\
\hline 6 & Drijfmest & Glufosinate & \\
\hline 6 & Drijfmest & Glyphosate & \\
\hline 6 & Drijfmest & Imidacloprid & 0.040 \\
\hline 6 & Drijfmest & Metamitron & 0.204 \\
\hline 6 & Drijfmest & Prosulfocarb & 0.008 \\
\hline 6 & Drijfmest & Spirodiclofen & 0.165 \\
\hline 6 & Drijfmest & Thiamethoxam & 0.091 \\
\hline 8 & Drijfmest & 2_4-D (vrije zuur) & 0.000 \\
\hline 8 & Drijfmest & 6-Benzyladenine & 0.001 \\
\hline 8 & Drijfmest & AMPA & \\
\hline 8 & Drijfmest & Antraquinon & 0.000 \\
\hline 8 & Drijfmest & BAC-12 & 0.026 \\
\hline 8 & Drijfmest & BAC-14 & 0.010 \\
\hline 8 & Drijfmest & Caffeine & \\
\hline 8 & Drijfmest & Chloorprofam & 0.000 \\
\hline 8 & Drijfmest & Cypermethrin & 0.000 \\
\hline 8 & Drijfmest & Deet & \\
\hline 8 & Drijfmest & Dichlobenil (afbr. chloorthiamide) & 0.003 \\
\hline 8 & Drijfmest & DIFENYL & 0.001 \\
\hline 8 & Drijfmest & Ethoxyquin & 0.305 \\
\hline 8 & Drijfmest & Etofenprox & 0.004 \\
\hline 8 & Drijfmest & Fenylfenol-2 & \\
\hline 8 & Drijfmest & Fluroxypyr (vrije zuur) & 0.051 \\
\hline 8 & Drijfmest & Fthalimide (afbr. folpet) & 0.051 \\
\hline 8 & Drijfmest & Glufosinate-ammonium & \\
\hline 8 & Drijfmest & Glyphosate & \\
\hline 8 & Drijfmest & Hexazinon & \\
\hline 8 & Drijfmest & MCPA (vrije zuur) & 0.001 \\
\hline 8 & Drijfmest & Mecoprop & 0.000 \\
\hline 8 & Drijfmest & Piperonyl-butoxide & 0.001 \\
\hline
\end{tabular}




\begin{tabular}{|c|c|c|c|}
\hline Bedrijf & Matrix & Middel & $\begin{array}{l}\text { Toxic Unit } \\
\text { (op basis van } \\
\text { droog gewicht) }\end{array}$ \\
\hline 8 & Drijfmest & Thiamethoxam & 0.012 \\
\hline 9 & Drijfmest & AMPA & \\
\hline 9 & Drijfmest & Antraquinon & 0.000 \\
\hline 9 & Drijfmest & Bixafen & 0.000 \\
\hline 9 & Drijfmest & Boscalid & 0.003 \\
\hline 9 & Drijfmest & Caffeine & \\
\hline 9 & Drijfmest & Deltamethrin & 0.216 \\
\hline 9 & Drijfmest & DIFENYL & 0.002 \\
\hline 9 & Drijfmest & Ethoxyquin & 0.305 \\
\hline 9 & Drijfmest & Fenylfenol-2 & \\
\hline 9 & Drijfmest & Glufosinate-ammonium & \\
\hline 9 & Drijfmest & Glyphosate & \\
\hline 9 & Drijfmest & Imazalil & 0.001 \\
\hline 9 & Drijfmest & Piperonyl-butoxide & 0.006 \\
\hline 9 & Drijfmest & Tebuconazole & 0.002 \\
\hline 10 & Drijfmest & 2_4-D (vrij zuur) & 0.000 \\
\hline 10 & Drijfmest & AMPA & \\
\hline 10 & Drijfmest & Glufosinate & \\
\hline 10 & Drijfmest & Glyphosate & \\
\hline 10 & Drijfmest & Piperonyl-butoxide & 0.001 \\
\hline 11 & Drijfmest & 2_4-D & 0.000 \\
\hline 11 & Drijfmest & AMPA & \\
\hline 11 & Drijfmest & Fluazifop (vrij zuur) & 0.000 \\
\hline 11 & Drijfmest & Glufosinate & \\
\hline 11 & Drijfmest & Glyphosate & \\
\hline 11 & Drijfmest & Haloxyfop (vrij zuur) & 0.001 \\
\hline 11 & Drijfmest & MCPA & 0.001 \\
\hline 11 & Drijfmest & Piperonyl-butoxide & 0.001 \\
\hline 12 & Drijfmest & 6-Benzyladenine & 0.001 \\
\hline 12 & Drijfmest & AMPA & \\
\hline 12 & Drijfmest & Epoxiconazole & 0.125 \\
\hline 12 & Drijfmest & Fluazifop (vrij zuur) & 0.000 \\
\hline 12 & Drijfmest & Fluazifop-p-butyl & 0.000 \\
\hline 12 & Drijfmest & Fluxapyroxad & 0.000 \\
\hline 12 & Drijfmest & Glufosinate & \\
\hline 12 & Drijfmest & Glyphosate & \\
\hline 12 & Drijfmest & Haloxyfop (vrij zuur) & 0.000 \\
\hline 12 & Drijfmest & MCPA & 0.001 \\
\hline 12 & Drijfmest & Mecoprop & 0.026 \\
\hline 12 & Drijfmest & Piperonyl-butoxide & 0.000 \\
\hline 13 & Drijfmest & 2_4-D (vrij zuur) & 0.000 \\
\hline 13 & Drijfmest & 6-Benzyladenine & 0.001 \\
\hline 13 & Drijfmest & AMPA & \\
\hline 13 & Drijfmest & Bixafen & 0.000 \\
\hline 13 & Drijfmest & Boscalid & 0.004 \\
\hline 13 & Drijfmest & Epoxiconazole & 0.187 \\
\hline 13 & Drijfmest & Fluxapyroxad & 0.000 \\
\hline 13 & Drijfmest & Glufosinate & \\
\hline 13 & Drijfmest & Glyphosate & \\
\hline 13 & Drijfmest & MCPA & 0.000 \\
\hline 13 & Drijfmest & MCPB & 0.000 \\
\hline 13 & Drijfmest & Tebuconazole & 0.000 \\
\hline 14 & Drijfmest & AMPA & \\
\hline 14 & Drijfmest & Diflubenzuron & 0.026 \\
\hline 14 & Drijfmest & Glufosinate & \\
\hline 14 & Drijfmest & Glyphosate & \\
\hline 14 & Drijfmest & Piperonyl-butoxide & 0.000 \\
\hline
\end{tabular}




\begin{tabular}{|c|c|c|c|}
\hline Bedrijf & Matrix & Middel & $\begin{array}{l}\text { Toxic Unit } \\
\text { (op basis van } \\
\text { droog gewicht) }\end{array}$ \\
\hline 15 & Drijfmest & 6-Benzyladenine & 0.001 \\
\hline 15 & Drijfmest & AMPA & \\
\hline 15 & Drijfmest & Chloorprofam & 0.000 \\
\hline 15 & Drijfmest & Glufosinate & \\
\hline 15 & Drijfmest & Glyphosate & \\
\hline 15 & Drijfmest & Haloxyfop (vrij zuur) & 0.000 \\
\hline 15 & Drijfmest & MCPA & 0.000 \\
\hline 15 & Drijfmest & Mecoprop & 0.002 \\
\hline 15 & Drijfmest & Piperonyl-butoxide & 0.000 \\
\hline 15 & Drijfmest & Thiamethoxam & 0.066 \\
\hline 16 & Drijfmest & AMPA & \\
\hline 16 & Drijfmest & Bixafen & 0.000 \\
\hline 16 & Drijfmest & Glufosinate & \\
\hline 16 & Drijfmest & Glyphosate & \\
\hline 16 & Drijfmest & Mecoprop & 0.000 \\
\hline 16 & Drijfmest & Piperonyl-butoxide & 0.000 \\
\hline 16 & Drijfmest & Prothioconazole-desthio & 0.001 \\
\hline 16 & Vaste mest & AMPA & \\
\hline 16 & Vaste mest & Antraquinon & 0.001 \\
\hline 16 & Vaste mest & Caffeine & \\
\hline 16 & Vaste mest & Glufosinate & \\
\hline 16 & Vaste mest & Glyphosate & \\
\hline 17 & Vaste mest & AMPA & \\
\hline 17 & Vaste mest & Antraquinon & 0.000 \\
\hline 17 & Vaste mest & Bixafen & 0.003 \\
\hline 17 & Vaste mest & Boscalid & 0.001 \\
\hline 17 & Vaste mest & Caffeine & \\
\hline 17 & Vaste mest & Chlorantraniliprole & 0.001 \\
\hline 17 & Vaste mest & Clothianidin & 0.005 \\
\hline 17 & Vaste mest & Cypermethrin (piek 1 t/m 4) & 0.000 \\
\hline 17 & Vaste mest & Cyprodinil & 0.001 \\
\hline 17 & Vaste mest & Cyromazine & 0.002 \\
\hline 17 & Vaste mest & Deltamethrin & 0.015 \\
\hline 17 & Vaste mest & DIFENYL & 0.000 \\
\hline 17 & Vaste mest & Epoxiconazole & 2.103 \\
\hline 17 & Vaste mest & Fluopyram & 0.001 \\
\hline 17 & Vaste mest & Fluxapyroxad & 0.008 \\
\hline 17 & Vaste mest & Glufosinate & \\
\hline 17 & Vaste mest & Glyphosate & \\
\hline 17 & Vaste mest & Lambda-cyhalothrin (piek $1+2$ ) & 0.000 \\
\hline 17 & Vaste mest & MCPA & 0.000 \\
\hline 17 & Vaste mest & $p, p^{\prime}-D D E$ & \\
\hline 17 & Vaste mest & Permethrin-cis & 0.000 \\
\hline 17 & Vaste mest & Permethrin-trans & 0.000 \\
\hline 17 & Vaste mest & Piperonyl-butoxide & 0.000 \\
\hline 17 & Vaste mest & Propiconazole & \\
\hline 17 & Vaste mest & Prothioconazole-desthio & 0.005 \\
\hline 17 & Vaste mest & Terbuthylazin-desethyl & 0.000 \\
\hline 17 & Vaste mest & Thiamethoxam & 0.004 \\
\hline 18 & Drijfmest & AMPA & \\
\hline 18 & Drijfmest & BAC-12 & 0.050 \\
\hline 18 & Drijfmest & BAC-14 & 0.034 \\
\hline 18 & Drijfmest & Bixafen & 0.000 \\
\hline 18 & Drijfmest & Chloorprofam & 0.000 \\
\hline 18 & Drijfmest & Cyfluthrin & 0.042 \\
\hline 18 & Drijfmest & DDAC & 0.003 \\
\hline 18 & Drijfmest & Deet & \\
\hline
\end{tabular}




\begin{tabular}{|c|c|c|c|}
\hline Bedrijf & Matrix & Middel & $\begin{array}{l}\text { Toxic Unit } \\
\text { (op basis van } \\
\text { droog gewicht) }\end{array}$ \\
\hline 18 & Drijfmest & Dichlorprop & 0.008 \\
\hline 18 & Drijfmest & Difenylamine & 0.001 \\
\hline 18 & Drijfmest & Diflufenican & 0.000 \\
\hline 18 & Drijfmest & Epoxiconazole & 0.217 \\
\hline 18 & Drijfmest & Fenpropimorph & 0.002 \\
\hline 18 & Drijfmest & Fenuron & 0.000 \\
\hline 18 & Drijfmest & Fipronil & 0.001 \\
\hline 18 & Drijfmest & Fipronil-Sulfone & \\
\hline 18 & Drijfmest & Fluxapyroxad & 0.003 \\
\hline 18 & Drijfmest & Glufosinate & \\
\hline 18 & Drijfmest & Glyphosate & \\
\hline 18 & Drijfmest & MCPA (vrij zuur) & 0.003 \\
\hline 18 & Drijfmest & Mecoprop & 0.000 \\
\hline 18 & Drijfmest & Permethrin-cis & 0.009 \\
\hline 18 & Drijfmest & Permethrin-trans & 0.015 \\
\hline 18 & Drijfmest & Piperonyl-butoxide & 0.137 \\
\hline 18 & Drijfmest & Prosulfocarb & 0.001 \\
\hline 18 & Drijfmest & Prothioconazole-desthio & 0.001 \\
\hline 18 & Drijfmest & Tebuconazole & 0.000 \\
\hline 19 & Vaste mest & AMPA & \\
\hline 19 & Vaste mest & Benzovindiflupyr & 0.002 \\
\hline 19 & Vaste mest & Bixafen & 0.002 \\
\hline 19 & Vaste mest & Boscalid & 0.004 \\
\hline 19 & Vaste mest & DIFENYL & 0.000 \\
\hline 19 & Vaste mest & Dinotefuran & 0.026 \\
\hline 19 & Vaste mest & Epoxiconazole & 0.154 \\
\hline 19 & Vaste mest & Fenpropimorph & 0.006 \\
\hline 19 & Vaste mest & Glufosinate & \\
\hline 19 & Vaste mest & Glyphosate & \\
\hline 19 & Vaste mest & Metconazole & 0.035 \\
\hline 19 & Vaste mest & Prothioconazole-desthio & 0.006 \\
\hline 19 & Vaste mest & Tebuconazole & 0.001 \\
\hline 20 & Drijfmest & 2_4-D (vrij zuur) & 0.000 \\
\hline 20 & Drijfmest & AMPA & \\
\hline 20 & Drijfmest & Antraquinon & 0.000 \\
\hline 20 & Drijfmest & DIFENYL & 0.000 \\
\hline 20 & Drijfmest & Difenylamine & 0.001 \\
\hline 20 & Drijfmest & Fluazifop (vrij zuur) & 0.000 \\
\hline 20 & Drijfmest & Glufosinate & \\
\hline 20 & Drijfmest & Glyphosate & \\
\hline 20 & Drijfmest & Haloxyfop (vrij zuur) & 0.000 \\
\hline 20 & Drijfmest & MCPA & 0.001 \\
\hline 20 & Drijfmest & Piperonyl-butoxide & 0.009 \\
\hline 20 & Drijfmest & Propiconazole & \\
\hline 20 & Drijfmest varkens & AMPA & \\
\hline 20 & Drijfmest varkens & BAC -12 & 0.006 \\
\hline 20 & Drijfmest varkens & BAC-14 & 0.004 \\
\hline 20 & Drijfmest varkens & Cypermethrin & 0.001 \\
\hline 20 & Drijfmest varkens & DDAC & 0.002 \\
\hline 20 & Drijfmest varkens & Deet & \\
\hline 20 & Drijfmest varkens & DIFENYL & 0.001 \\
\hline 20 & Drijfmest varkens & Difenylamine & 0.001 \\
\hline 20 & Drijfmest varkens & Ethoxyquin & 0.840 \\
\hline 20 & Drijfmest varkens & Fenuron & 0.000 \\
\hline 20 & Drijfmest varkens & Fipronil & 0.000 \\
\hline 20 & Drijfmest varkens & Fipronil-Sulfone & $5.94 * 10^{-7}$ \\
\hline 20 & Drijfmest varkens & Fluazifop & 0.002 \\
\hline
\end{tabular}




\begin{tabular}{|c|c|c|c|}
\hline Bedrijf & Matrix & Middel & $\begin{array}{l}\text { Toxic Unit } \\
\text { (op basis van } \\
\text { droog gewicht) }\end{array}$ \\
\hline 20 & Drijfmest varkens & Fluazinam & 0.000 \\
\hline 20 & Drijfmest varkens & Fosthiazate & 0.000 \\
\hline 20 & Drijfmest varkens & Glufosinate & \\
\hline 20 & Drijfmest varkens & Glyphosate & \\
\hline 20 & Drijfmest varkens & Haloxyfop (vrij zuur) & 0.004 \\
\hline 20 & Drijfmest varkens & Metalaxyl & 0.000 \\
\hline 20 & Drijfmest varkens & Picaridin & \\
\hline 20 & Drijfmest varkens & Piperonyl-butoxide & 0.023 \\
\hline 20 & Drijfmest varkens & Pirimicarb & 0.000 \\
\hline 20 & Drijfmest varkens & Prochloraz desimidazole-amino & 0.000 \\
\hline 20 & Drijfmest varkens & Prosulfocarb & 0.001 \\
\hline 20 & Drijfmest varkens & Thiabendazole & 0.001 \\
\hline 21 & Drijfmest & AMPA & \\
\hline 21 & Drijfmest & Bixafen & 0.005 \\
\hline 21 & Drijfmest & Boscalid & 0.001 \\
\hline 21 & Drijfmest & DIFENYL & 0.000 \\
\hline 21 & Drijfmest & Epoxiconazole & 0.267 \\
\hline 21 & Drijfmest & Fluopyram & 0.000 \\
\hline 21 & Drijfmest & Fluxapyroxad & 0.002 \\
\hline 21 & Drijfmest & Glufosinate & \\
\hline 21 & Drijfmest & Glyphosate & \\
\hline 21 & Drijfmest & Metconazole & 0.027 \\
\hline 21 & Drijfmest & Piperonyl-butoxide & 0.004 \\
\hline 21 & Drijfmest & Prothioconazole-desthio & 0.002 \\
\hline 21 & Drijfmest & Tebuconazole & 0.001 \\
\hline 21 & Vaste mest & AMPA & \\
\hline 21 & Vaste mest & Bixafen & 0.001 \\
\hline 21 & Vaste mest & Boscalid & 0.001 \\
\hline 21 & Vaste mest & Epoxiconazole & 0.051 \\
\hline 21 & Vaste mest & Fluopyram & 0.000 \\
\hline 21 & Vaste mest & Fluxapyroxad & 0.002 \\
\hline 21 & Vaste mest & Glufosinate & \\
\hline 21 & Vaste mest & Glyphosate & \\
\hline 21 & Vaste mest & Metconazole & 0.003 \\
\hline 21 & Vaste mest & Prothioconazole-desthio & 0.001 \\
\hline 21 & Vaste mest & Tebuconazole & 0.008 \\
\hline 22 & Drijfmest & 6-Benzyladenine & 0.001 \\
\hline 22 & Drijfmest & AMPA & \\
\hline 22 & Drijfmest & Caffeine & \\
\hline 22 & Drijfmest & Cinnerin 1 & 0.042 \\
\hline 22 & Drijfmest & Glufosinate & \\
\hline 22 & Drijfmest & Glyphosate & \\
\hline 22 & Drijfmest & Haloxyfop (vrij zuur) & 0.000 \\
\hline 22 & Drijfmest & Jasmolin 1 & 0.000 \\
\hline 22 & Drijfmest & Jasmolin 2 & 0.013 \\
\hline 22 & Drijfmest & MCPA & 0.001 \\
\hline 22 & Drijfmest & Piperonyl-butoxide & 0.050 \\
\hline 22 & Drijfmest & Pyrethrin 1 & 0.052 \\
\hline 22 & Drijfmest & Pyrethrin 2 & 0.020 \\
\hline 23 & Drijfmest & 2_4-DB (vrij zuur) & 0.000 \\
\hline 23 & Drijfmest & 6-Benzyladenine & 0.000 \\
\hline 23 & Drijfmest & AMPA & \\
\hline 23 & Drijfmest & BAC-12 & 0.000 \\
\hline 23 & Drijfmest & BAC-14 & 0.000 \\
\hline 23 & Drijfmest & Bixafen & 0.000 \\
\hline 23 & Drijfmest & Caffeine & \\
\hline 23 & Drijfmest & Carbetamide & 0.000 \\
\hline
\end{tabular}




\begin{tabular}{|c|c|c|c|}
\hline Bedrijf & Matrix & Middel & $\begin{array}{l}\text { Toxic Unit } \\
\text { (op basis van } \\
\text { droog gewicht) }\end{array}$ \\
\hline 23 & Drijfmest & Carbofuran & 0.001 \\
\hline 23 & Drijfmest & Chloorprofam & 0.000 \\
\hline 23 & Drijfmest & Cyproconazool & 0.001 \\
\hline 23 & Drijfmest & DDAC & 0.001 \\
\hline 23 & Drijfmest & Deet & \\
\hline 23 & Drijfmest & Dichlobenil (afbr. chloorthiamide) & 0.000 \\
\hline 23 & Drijfmest & Difenylamine & 0.001 \\
\hline 23 & Drijfmest & Dodemorph & 0.000 \\
\hline 23 & Drijfmest & Ethoxyquin & 0.171 \\
\hline 23 & Drijfmest & Fenamiphos & 0.003 \\
\hline 23 & Drijfmest & Fenamiphos-sulfone & 0.000 \\
\hline 23 & Drijfmest & Fenamiphos-sulfoxide & 0.000 \\
\hline 23 & Drijfmest & Fenpiclonil & 0.000 \\
\hline 23 & Drijfmest & Fenthion & 0.000 \\
\hline 23 & Drijfmest & Fenuron & 0.000 \\
\hline 23 & Drijfmest & Fipronil-Sulfone & $4.4 * 10^{-7}$ \\
\hline 23 & Drijfmest & Fluazifop (vrij zuur) & 0.000 \\
\hline 23 & Drijfmest & Fludioxonil & 0.000 \\
\hline 23 & Drijfmest & Flusilazool & 0.001 \\
\hline 23 & Drijfmest & Fluxapyroxad & 0.000 \\
\hline 23 & Drijfmest & Fosthiazate & 0.000 \\
\hline 23 & Drijfmest & Furalaxyl & 0.000 \\
\hline 23 & Drijfmest & Glufosinate & \\
\hline 23 & Drijfmest & Glyphosate & \\
\hline 23 & Drijfmest & Haloxyfop (vrij zuur) & 0.001 \\
\hline 23 & Drijfmest & Imazalil & 0.000 \\
\hline 23 & Drijfmest & Lenacil & 0.000 \\
\hline 23 & Drijfmest & Mecoprop (vrij zuur) & 0.003 \\
\hline 23 & Drijfmest & Mephosfolan & 0.722 \\
\hline 23 & Drijfmest & Metalaxyl & 0.000 \\
\hline 23 & Drijfmest & Monolinuron & 0.000 \\
\hline 23 & Drijfmest & Penconazool & 0.001 \\
\hline 23 & Drijfmest & Picaridin & \\
\hline 23 & Drijfmest & Piperonyl-butoxide & 0.007 \\
\hline 23 & Drijfmest & Pirimicarb & 0.000 \\
\hline 23 & Drijfmest & Prosulfocarb & 0.000 \\
\hline 23 & Drijfmest & Tetraconazool & 0.000 \\
\hline 23 & Drijfmest & Thiabendazole & 0.001 \\
\hline 23 & Drijfmest & Vamidothion & 0.022 \\
\hline 24 & Drijfmest & 6-Benzyladenine & 0.001 \\
\hline 24 & Drijfmest & AMPA & \\
\hline 24 & Drijfmest & Antraquinon & 0.000 \\
\hline 24 & Drijfmest & Caffeine & \\
\hline 24 & Drijfmest & Epoxiconazole & 0.152 \\
\hline 24 & Drijfmest & Glufosinate & \\
\hline 24 & Drijfmest & Glyphosate & \\
\hline 24 & Drijfmest & Piperonyl-butoxide & 0.001 \\
\hline 24 & Drijfmest & Tebuconazole & 0.000 \\
\hline 24 & Vaste mest & AMPA & \\
\hline 24 & Vaste mest & Benzovindiflupyr & 0.000 \\
\hline 24 & Vaste mest & Bixafen & 0.022 \\
\hline 24 & Vaste mest & Boscalid & 0.001 \\
\hline 24 & Vaste mest & Caffeine & \\
\hline 24 & Vaste mest & Chlorothalonil-4-hydroxy & 0.0003 \\
\hline 24 & Vaste mest & Cyproconazool & 0.001 \\
\hline 24 & Vaste mest & DIFENYL & 0.000 \\
\hline 24 & Vaste mest & Epoxiconazole & 0.938 \\
\hline
\end{tabular}




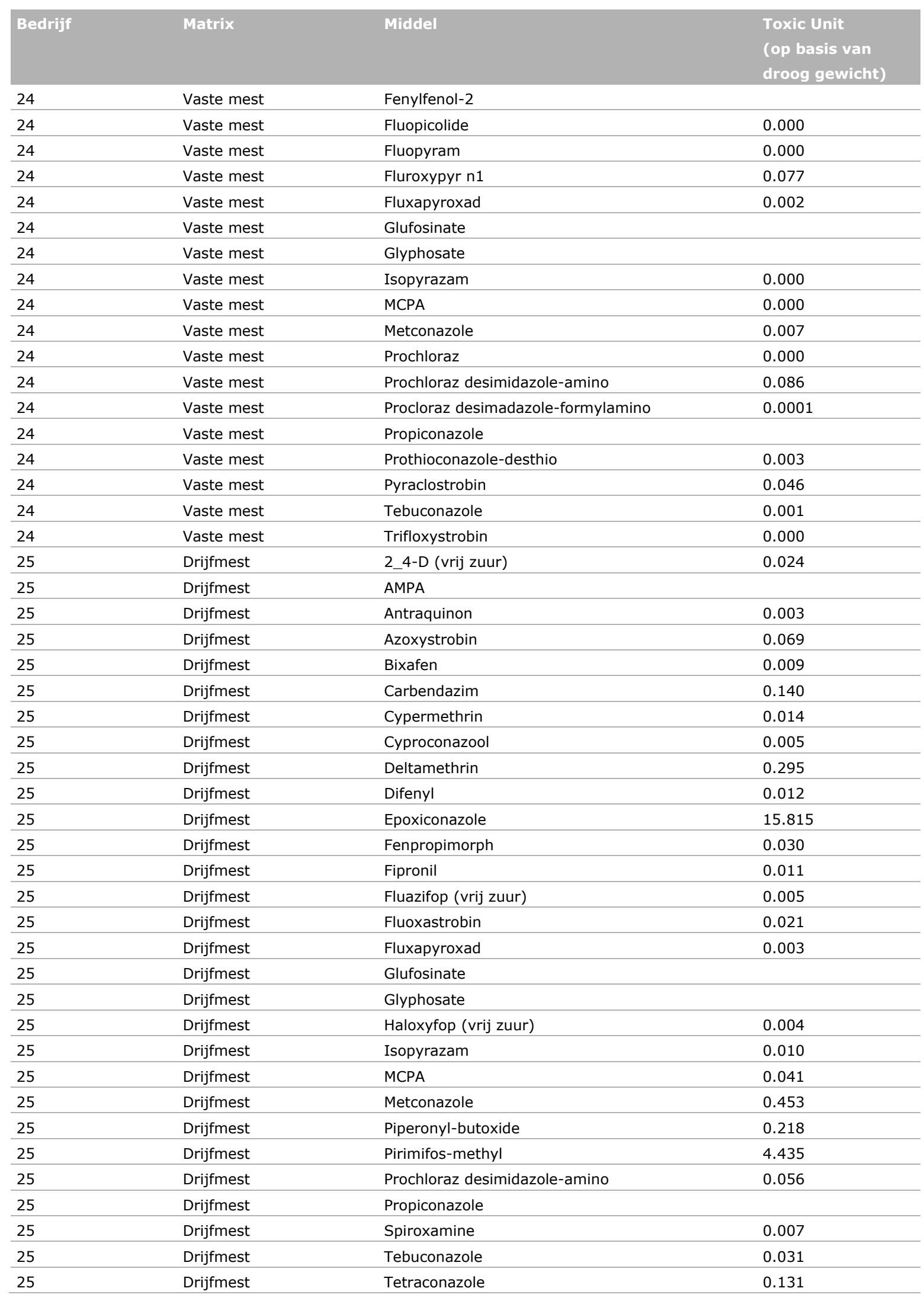




\section{Bijlage 7 Enkele losse observaties}

De (ad hoc) MTR-waarden voor water en sediment van piperonyl-butoxide (Rijkswaterstaat, 2008), overgenomen uit het RIVM zoeksysteem (https://rvszoeksysteem.rivm.nl/Stoffen). De MTR in sediment/grond $(0.389 \mu \mathrm{g} / \mathrm{kg}$ droog) is correct. De MTR in water $(0.000083 \mu \mathrm{g} / \mathrm{L})$ bleek bij controle onjuist in het systeem te staan als $0.00083 \mu \mathrm{g} / \mathrm{L}$, wat op 19 februari 2020 aan het RIVM is gemeld. Hierop is de waarde op 24 februari 2020 in het zoeksysteem aangepast.

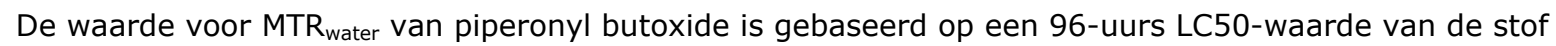
voor een marine kreeftachtige (Penaeus duorarum; LC50=1.25 $\mathrm{gg} / \mathrm{L}$ ) die veel gevoeliger lijkt dan op basis van LC50-waarden voor andere vissen (LC50 0.19-0.49 mg/L) en kreeftachtigen (LC50 1.6$12 \mathrm{mg} / \mathrm{L}$ ) kan worden verwacht. De afgeleide MTR lijkt erg conservatief, omdat voor de afleiding van MTR $_{\text {water }}$ alleen een enkele acute toxiciteitswaarde beschikbaar was en een erg hoge veiligheidsfactor (3000 en additionele factor van 5 wegens mogelijke doorvergiftiging) zijn gebruikt (mondelinge mededeling RIVM, 19 februari 2020). Omdat er een alternatieve waarde (ECHA PNEC van $0.098 \mathrm{mg} / \mathrm{kg}$ ) beschikbaar was, is de MTR voor piperonyl butoxide niet gebruikt.

Bij de meetresultaten voor krachtvoer bemonsterd op bedrijf 3 worden twee verschillende waarden gegeven voor het gehalte aan piperonyl-butoxide (3.89 resp. $2.08 \mu \mathrm{g} / \mathrm{kg}$ vers gewicht). Dit heeft verder voor dit onderzoek geen consequenties, omdat de metingen in krachtvoer niet zijn gebruikt voor een ecotoxicologische beoordeling.

De waarde voor MTR water van pirimifos-methyl (Mensink, 2008) is gebaseerd op een NOEC van de stof voor de watervlo Daphnia magna. Er is een 'normale' veiligheidsfactor (100) gebruikt in de afleiding van de MTRwater.

De waarde voor MTR water van mefosfolan (Oste et al., 2010) is gebaseerd op een 96-uurs LC50-waarde van de stof voor een zoetwater vis (Carassius auratus, de Goudvis), waarvan wordt aangegeven dat de waarde een 'lage betrouwbaarheid' heeft. Er is een hoge veiligheidsfactor (3000) gebruikt in de afleiding van $\mathrm{MTR}_{\text {water }}$. 
Wageningen Environmental Research Postbus 47

6700 AA Wageningen

T 0317480700

www.wur.nl/environmental-research

Wageningen Environmental Research

Rapport 3037

ISSN 1566-7197
De missie van Wageningen University \& Research is 'To explore the potential of nature to improve the quality of life'. Binnen Wageningen University \& Research bundelen Wageningen University en gespecialiseerde onderzoeksinstituten van Stichting Wageningen Research hun krachten om bij te dragen aan de oplossing van belangrijke vragen in het domein van gezonde voeding en leefomgeving. Met ongeveer 30 vestigingen, 6.500 medewerkers ( $5.500 \mathrm{fte}$ ) en 12.500 studenten behoort Wageningen University \& Research wereldwijd tot de aansprekende kennisinstellingen binnen haar domein. De integrale benadering van de vraagstukken en de samenwerking tussen verschillende disciplines vormen het hart van de unieke Wageningen aanpak. 


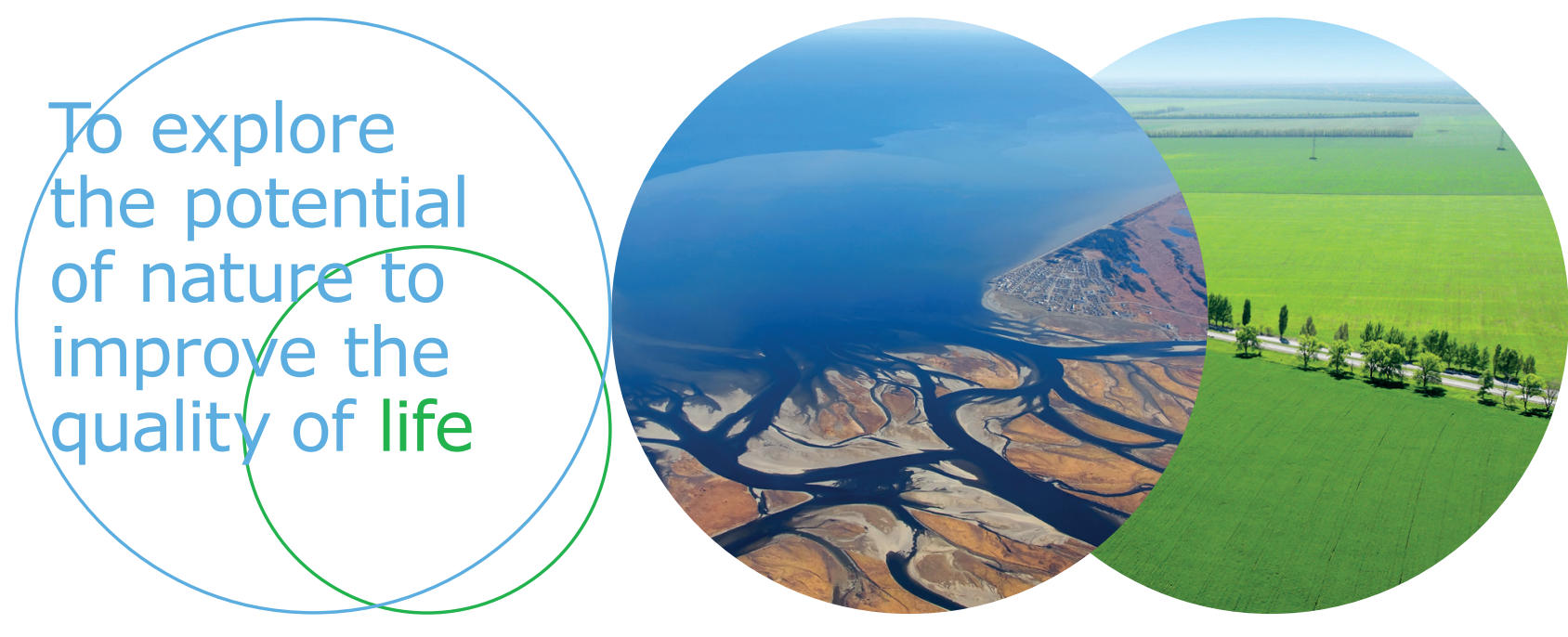

Wageningen Environmental Research Postbus 47

$6700 \mathrm{AB}$ Wageningen

T 317480700

www.wur.nl/environmental-research

Rapport 3037

ISSN 1566-7197
De missie van Wageningen University \& Research is 'To explore the potential of nature to improve the quality of life'. Binnen Wageningen University \& Research bundelen Wageningen University en gespecialiseerde onderzoeksinstituten van Stichting Wageningen Research hun krachten om bij te dragen aan de oplossing van belangrijke vragen in het domein van gezonde voeding en leefomgeving. Met ongeveer 30 vestigingen, 6.500 medewerkers ( $5.000 \mathrm{fte}$ ) en 12.500 studenten behoort Wageningen University \& Research wereldwijd tot de aansprekende kennisinstellingen binnen haar domein. De integrale benadering van de vraagstukken en de samenwerking tussen verschillende disciplines vormen het hart van de unieke Wageningen aanpak. 